\title{
SERI Results from the PEP 1987 Summit Round Robin and a Comparison of Photovoltaic Calibration Methods
}

\author{
K. A. Emery \\ D. Waddington \\ S. Rummel \\ D. R. Myers \\ T. L. Stoffel \\ C. R. Osterwald
}

March 1989

Prepared under Task Nos. PV920202, PV920601, and PV810201

Solar Energy Research Institute A Division of Midwest Research Institute

1617 Cole Boulevard

Golden, Colorado 80401-3393

Prepared for the U.S. Department of Energy

Contract No. DE-AC02-83CH10093 


\section{NOTICE}

This report was prepared as an account of work sponsored by an agency of the United States government. Neither the United States government nor any agency thereof, nor any of their employees, makes any warranty, express or implied, or assumes any legal liability or responsibility for the accuracy, completeness, or usefuiness of any information, apparatus, product, or process disclosed, or represents that its use would not infringe privately owned rights. Reference herein to any specific commercial product, process, or service by trade name, trademark, manufacturer, or otherwise does not necessarily constitute or imply its endorsement, recommendation, or favoring by the United States government or any agency thereof. The views and opinions of authors expressed herein do not necessarily state or reflect those of the United States government or any agency thereof.

\section{Printed in the United States of America Available from: \\ National Technical Information Service \\ U.S. Department of Commerce \\ 5285 Port Royal Road \\ Springtield, VA 22161 \\ Price: Microfiche A01 \\ Printed Copy A05}

Codes are used for pricing all publications. The code is determined by the number of pages in the publication. Information pertaining to the pricing codes can be found in the current issue of the following publications which are generally availabie in most libraries: Energy Research Abstracts (ERA); Govern. ment Reports Announcements and Index (GRA and I); Scientific and Technical Abstract Reports (STAR); and publication NTIS-PR-360 available from NTIS at the above address. 


\section{PREFACE}

This report presents the SERI results from the Photovoltaic Solar Energy Project (PEP) 1987 Summit Round Robin. Different primary PV calibration methods, including global-normal, global fixed-tilt, and direct-normal, are investigated. The merits and problems of these calibration procedures are discussed, with particular attention given to the proposed International Electrotechnical Commission (IEC) global method.

The authors wish to thank R. DeBlasio, R. Hulstrom, L. Kazmerski, C. Riordan, C. Wells, T. Cannon, E. Maxwell, and L. Mrig for their constructive technical reviews.

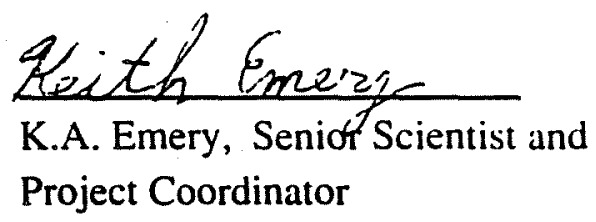

Approved for

SOLAR ENERGY RESEARCH INSTITUTE

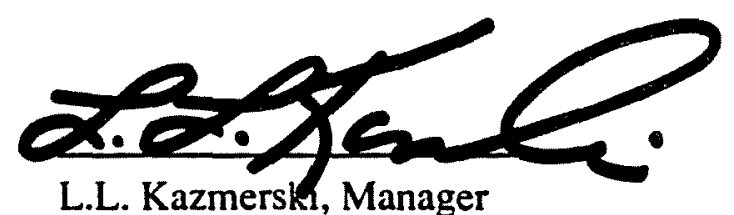

Photovoltaic Measurements and

Performance Branch

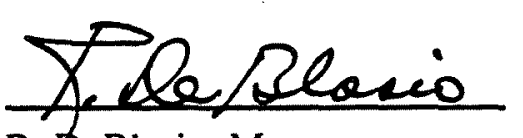

R. DeBlasio, Manager Advanced Photovoltaic Module Testing and Performance Section
J.L. Stone, Director

Solar Electric Research Division

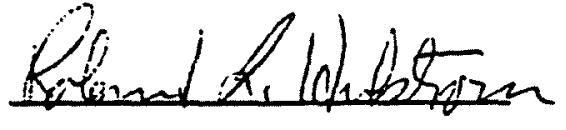

R.L. Hulstrom, Manager Resource Assessment and Instrumentation Branch 
page 28, Table 3-3.

At $\lambda=360 \mathrm{~nm}$ for sample RC-01 $S_{r}(\lambda)=0.0601$ instead of 0.6014

page 31, Table 3-4.

For sample RM-02 and the Global Fixed-Tilt, Pyranometer column the value should be 0.09779 instead of 0.09797

pages 64 and 65, Tables B-3 and B-4

The part of the Table B-3 marked Data of Reference Cell RM-01 is reversed with the data in Table B-4 marked Data of Reference Cell RM-02.

The part of the Table B-3 marked Data of Reference Cell SM-01 is reversed with the data in Table B-4 marked Data of Reference Cell SM-02.

The manufacturer and technology of the PEP'87 samples are listed in the following Table

\begin{tabular}{|c|c|c|}
\hline sample & technology & manufacturer \\
\hline RC-01, RM-01, SM-01 & amorphous silicon on glass & Sanyo \\
\hline RC-02, RM-02, SM-02 & amorphous silicon on glass & Sanyo \\
\hline RC-03, RM-03, SM-03 & monocrystal-silicon $(\mathrm{CZ})$ & Siemens \\
\hline RC-04, RM-04, SM-04 & monocrystal-silicon (CZ) & Siemens \\
\hline RC-05, RM-05, SM-05 & polycrystal-silicon & AEG \\
\hline RC-06, RM-06, SM-06 & polycrystal-silicon & AEG \\
\hline RC-07 & monocrystal-silicon (float-zone) & Telefunken \\
\hline \multirow[t]{2}{*}{ RC-08 } & monocrystal-silicon with a Schott & \\
\hline & BG18 color glass filter & Telefunken \\
\hline
\end{tabular}




\section{EXECUTIVE SUMMARY}

This report contains the SERI results from the Photovoltaic Solar Energy Project (PEP) 1987 Summit Round Robin. The organizing agent for this intercomparison was Dr. J. Metzdorf of PhysikalishTechnische Bundesanstalt (PTB) of the Federal Republic of Germany. The current-versus-voltage $(I-V)$ characteristics and temperature coefficients were determined for all of the PEP '87 modules, reference cells in single-cell packages, and reference cells in multiple-cell packages. The absolute external spectral response was measured for the reference cells in single-cell and multiple-cell packages. The PEP ' 87 data sheets requested by the organizing agent are given in Appendix B.

The proposed International Electrotechnical Commission (IEC) Technical Committee 82 (TC82) Working Group 2 (WG2) global calibration method (Table A-1) is compared using both a south-facing, fixed-tilt and a tracking, normal-incidence scheme. These global calibration methods are then compared with primary direct-normal, primary air-mass zero (AM0), and secondary calibrations performed in a simulator. The SERI standard procedure uses secondary calibrations against primary reference cells calibrated under direct-normal $\left(5^{\circ}\right.$ field-of-view) irradiance.

The results of this study indicate that the global calibration method has a $\pm 4 \%$ uncertainty in the short-circuit current $\left(I_{s c}\right)$ under standard reporting conditions, including bias and random error sources. The uncertainty in $I_{s c}$ can be reduced to $\pm 3 \%$ if the direct component of the total irradiance is measured with a primary absolute cavity radiometer and a shaded pyranometer to measure the plane-of-measurement diffuse component. Primary and simulator-based secondary calibration methods are available for which the uncertainty limits are less than $\pm 2 \%$. The majority of the estimated uncertainty for these PV calibration methods is due nonrandom, or bias, sources of error.

The $I_{s c}$ determined with all of the PV calibration methods agreed within $\pm 4 \%$, and there was no apparent difference in the estimated uncertainty between the PV modules and the reference cells in single- or multiple-cell packages. If a $\pm 4 \%$ uncertainty in $I_{s c}$ under standard reporting conditions is acceptable, then the global calibration method with spectral corrections is suitable for cells or modules. If a primary reference device with an uncertainty of less than $\pm 3 \%$ is required, then the global method is unsuitable.

The SERI primary direct-normal calibration method, which is equivalent to the global method with a $5^{\circ}$ field-of-view, has an estimated uncertainty of $\pm 1 \%$. This uncertainty limit was verified by comparison with primary AM0 cells. The direct-normal method at present is only available for cells less than $3.3 \mathrm{~cm}$ in diameter. If a $\pm 1 \%$ primary reference cell is used for simulator or outdoor secondary calibrations, then an uncertainty of less than $\pm 2 \%$ can be achieved for reference cells in single-cell packages, reference cells in multiple-cell packages, or modules. 


\section{TABLE OF CONTENTS}

$1.0 \quad$ Introduction

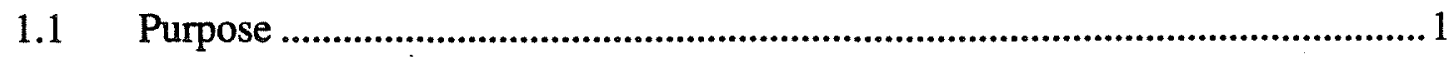

1.2 Organization of Report ........................................................................................

1.3 Background of the Reference Cell Method ............................................................2

2.0 Measurement Procedures and Uncertainty Analysis .................................................3

$2.1 \quad$ Uncertainty Formulation ...................................................................................

2.2 Primary Absolute Cavity Radiometer ............................................................4

2.3 Global Pyranometer Calibration.......................................................................

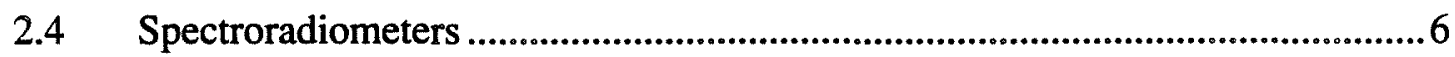

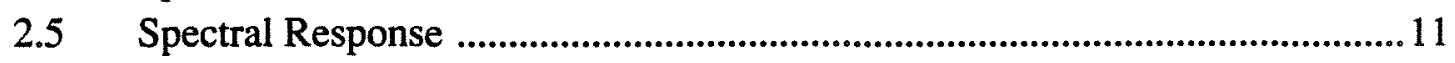

$2.6 \quad$ PV Calibration Uncertainty ……................................................................13

2.6.1 Global Calibration Methods ............................................................... 13

2.6.2 Direct-Normal Method Used at SERI ................................................. 19

2.6.3 Simulator-Based Secondary Calibration ............................................20

2.6.4 Summary of PV Calibration Uncertainties ............................................24

3.0 SERI PV Calibration Results for the PEP '87 Intercomparison ..................................25

$3.1 \quad$ Experimental Approach ...................................................................................25

3.2 Reference Cells in Single-Cell Packages........................................................25

3.2.1 Data Summary ..................................................................................25

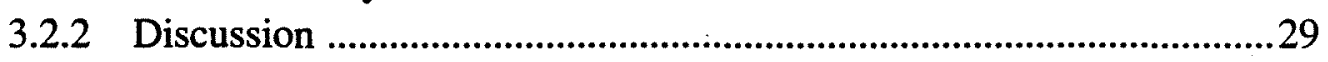

3.3 Reference Devices in Multiple-Cell Packages ...............................................29

3.3.1 Data Summary .................................................................................229

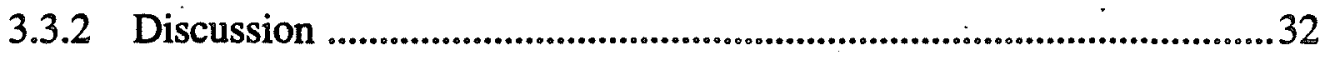

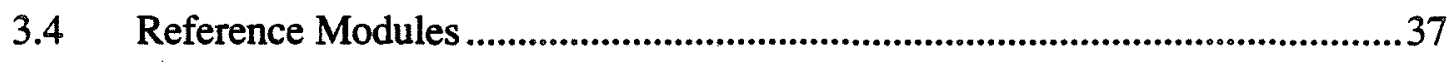

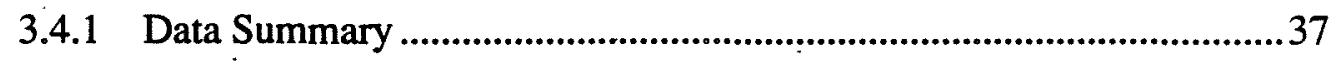

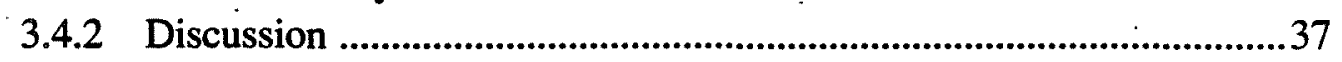

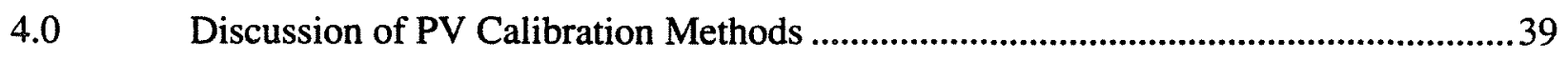

4.1 Proposed IEC Global Calibration Method ..........................................................39

4.1.1 Air Mass, Elevation Angle, and Angle of Incidence.............................39

4.1.2 Sample Interval .............................................................................40

4.1.3 Ground Reflections ...................................................................................41

4.1.4 Total Irradiance ..................................................................................4 42

4.1.5 Integration Limits ................................................................................ 42

4.1.6 Determination of the Spectral Correction Factor ..................................43

4.1.7 Uncertainty .............................................................................................4 
Page

4.2 Global-Horizontal, Global-Normal, and Global Fixed-Tilt Methods .45

4.3 Comparison of Direct and Global Calibration Methods ....................................46

4.4 Simulator-Based Secondary Calibrations ........................................................49

4.5 Reference Device Package Designs ..............................................................51

5.0 Summary and Recommendations ..............................................................................

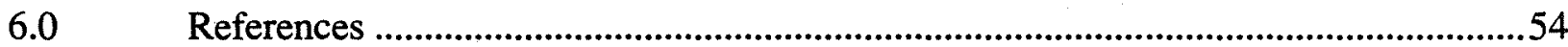

Appendix A IEC TC82 Global Calibration Method and Global Reference Spectrum .........57

Appendix B Data Sheets for the PEP 1987 Summit Round Robin ......................................61

Appendix.C Uncorrected Data for Global Fixed-Tilt and Spire SPI-SUN 240

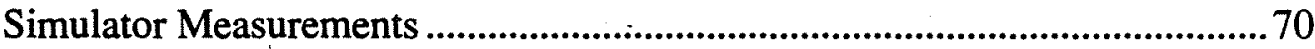




\section{LIST OF FIGURES}

Page

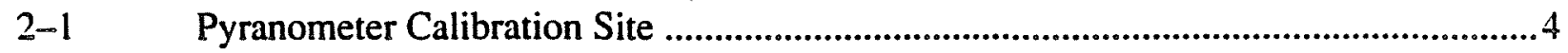

2-2 Calibration Plot for PEP '87 Kipp \& Zonen CM11-4 ................................................. 7

2-3 Calibration Plot for Eppley PSP 17863F3 Used for Global-Normal Diffuse

Measurements............................................................................................................................ 7

2-4 Calibration Plot for Eppley PSP 24191F3 Used for Global-Normal

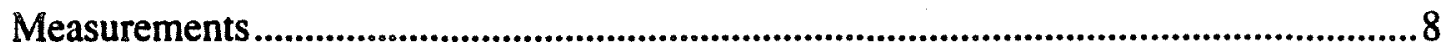

2-5 Calibration Plot for SERI Kipp \& Zonen CM11 830092 Used for

Global-Normal Measurements ..........................................................................................

2-6 Calibration Plot for Eppley PSP 25952F3 Used for Global Fixed-Tilt

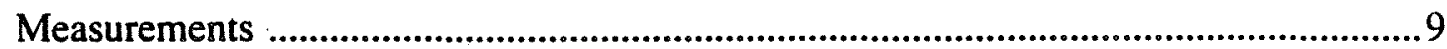

2-7. Calibration Plot for Eppley PSP 24034F3 Used for Global Fixed-Tilt

Diffuse Measurements ..........................................................................................9

2-8 PEP '87 Kipp \& Zonen CM11-4 Calibration is. Body Temperature ............................ 10

2-9 Temperature Response of Three Kipp \& Zonen CM11 Pyranometers

Determined at Five Laboratories over a Four Year Period ............................................. 10

2-10 Photograph of the SERI Spectral Response Measurement System................................12

2-11 Solar Geometry Relative to the Plane-of-Measurement .............................................. 14

2-12 Photograph of the SERI Advanced PV Module Test Facility and Global

Fixed-Tilt Calibration Site ..........................................................................................15

2-13 Sample Mounting Detail for Global Fixed-Tilt Calibrations ........................................ 16

2-14 South Table Mountain Test Site Used for Global-Normal and

Direct-Normal Calibrations ......................................................................................... 17

2-15 Sample Mounting Detail for Global-Normal Calibrations ............................................ 18

2-16 Sample Mounting Detail for Direct-Normal Calibrations ............................................220

2-17 Spectrolab X-25 Solar Simulator with Custom Data Aquisition System ....................22

2-18 Spectral Irradiance of Spectrolab X-25 Simulator ......................................................22

2-19 Spire SPI-SUN Model 240 PV Measurement System ....................................................23

2-20 SPI-SUN Model 240 Spectral Irradiance Supplied by Spire .........................................23

3-1 $\quad C V /\langle C V\rangle v s$. Solar Elevation for $E_{\text {tot }}$ Measured with Kipp \& Zonen

CM11 830092

3-2 $C V /\langle C V\rangle$ vs. Solar Elevation for $E_{t u t}$ Measured with

Direct-Plus-Diffuse Irradiance .......................................................................................30

3-3 Ratio of the Plane-of-Measurement Total Irradiance Above the PV

Samples to the Total Irradiance at the Center of the Plane-of-Measurement 
3-4 CV / $\langle C V\rangle$ vs. Solar Incidence Angle for $E_{t o t}$ Measured Using the PEP '87 Kipp \& Zonen Pyranometer .

3-5 $\quad C V /\langle C V\rangle$ vs. Solar Incidence Angle for $E_{\text {tox }}$ Measured Using the

Direct-Plus-Diffuse Irradiance Method

3-6 Total Irradiance Ratio Above and to the East of the Global Fixed-Tilt

Sample Plane as a Function of Solar Incidence Angle.................................................36

4-1 Possible Error in Total Irradiance Due to Misalignment ..............................................40

4-2 Ratio of Spectral Correction Factor Determined with Teflon Dome to

Integrating Sphere vs. Solar Incidence Angle .

4-3 Variation in the X-25 Simulator Calibration Values for Nine Primary AM0

Reference Cells . 


\section{LIST OF TABLES}

Page

2-1 $\quad U_{95}$ Pyranometer Calibration Uncertainty ……..............................................................

2-2 Global Fixed-Tilt $U_{95}$ Calibration Uncertainty ............................................................. 17

2-3 Global-Normal $U_{95}$ Calibration Uncertainty Using a Movable

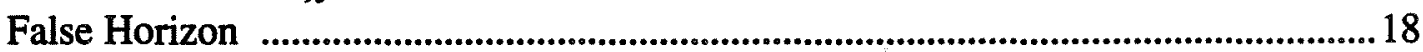

2-4 Direct-Normal $U_{95}$ Calibration Uncertainty ...............................................................20

2-5 $U_{95}$ Uncertainty Limits for Spectrolab X-25 Solar Simulator Calibration ...................21

2-6 $U_{95}$ Uncertainty Limits for Spire SPI-SUN 240 Solar Simulator Calibration ...............24

2-7 Summary of PV Calibration Uncertainties ................................................................24

3-1 Summary of $I_{s c}$ Calibrations for Reference Cells in Single-Cell Packages .................26

3-2 $I_{s c}$ Temperature Coefficients Normalized to $25^{\circ} \mathrm{C}$.......................................................27

3-3 Absolute Spectral Response for $4 \mathrm{~cm}^{2}$ Reference Cells in

Single-Cell Packages ....................................................................................................28

3-4 Summary of $I_{s c}$ Calibrations for Reference Devices in Multiple-Cell Packages..........31

3-5 Summary of $I-V$ Parameters for Reference Devices in Multiple-Cell Packages ........33

3-6 Absolute Spectral Response for $100 \mathrm{~cm}^{2}$ Reference Cells in Multiple-Cell Packages .....................................................................................................34

3-7 Summary of $I_{s c}$ Calibrations for Reference Modules ........................................................37

3-8 Summary of $I-V$ Parameters for Reference Modules....................................................38

4-1 Effect of Changing Integration Limits on the Spectrally Corrected

Calibration Value .........................................................................................................4

4-2 Range of Values of the Spectral Correction Factor $k$.....................................................4

4-3 Direct vs. Global Calibration Methods ...............................................................................4 47

4-4 Absolute Spectral Response for $4 \mathrm{~cm}^{2}$ SERI Primary Reference Cells .......................48

4-5 Measurement of One Primary AM0 Reference Cell with Several Primary

Direct-Normal Calibrated Terrestrial Reference Cells ...................................................50

A-1 Primary Reference Device Calibration Methods ..............................................................57

A-2 IEC TC82 Global Reference Spectral Irradiance Distribution Normalized

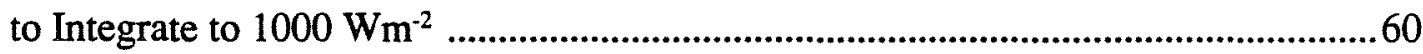

B-1 Test Data Sheet for Pyranometer ...............................................................................62

B-2 Test Data Sheet for Reference Devices ........................................................................63

B-3 Test Data Sheet for Solar Module SM-01 .......................................................................64

B-4 Test Data Sheet for Solar Module SM-02 .........................................................................65

B-5 Test Data Sheet for Solar Module SM-03 ..................................................................66

B-6 Test Data. Sheet for Solar Module SM-04 .........................................................6.

B-7 Test Data Sheet for Solar Module SM-05 ...................................................................6

B-8 Test Data Sheet for Solar Module SM-06 ..........................................................69 
Page

C-1 Global Fixed-Tilt and SPI-SUN 240 Data for Sample RM-01 ...............................71

C-2 Global Fixed-Tilt and SPI-SUN 240 Data for Sample RM-02 ..............................72

C-3 Global Fixed-Tilt and SPI-SUN 240 Data for Sample RM-03 ...............................73

C-4 Global Fixed-Tilt and SPI-SUN 240 Data for Sample RM-04 ...............................74

C-5 Global Fixed-Tilt and SPI-SUN 240 Data for Sample RM-05 .................................75

C-6 Global Fixed-Tilt and SPI-SUN 240 Data for Sample RM-06 .................................76

C-7 Global Fixed-Tilt and SPI-SUN 240 Data for Sample SM-01 ................................77

C-8 Global Fixed-Tilt and SPI-SUN 240 Data for Sample SM-02 ................................78

C-9 Global Fixed-Tilt and SPI-SUN 240 Data for Sample SM-03 ................................79

C-10 Global Fixed-Tilt and SPI-SUN 240 Data for Sample SM-04 .................................80

C-11 Global Fixed-Tilt and SPI-SUN 240 Data for Sample SM-05 ..............................81

C-12 Global Fixed-Tilt and SPI-SUN 240 Data for Sample SM-06 ...............................82 


\title{
NOMENCLATURE
}

\author{
$\alpha$ \\ $\gamma$ \\ $\theta$ \\ $\theta_{i}$ \\ $\lambda$ \\ $\rho$ \\ $\sigma$ \\ $\phi$ \\ $\Psi$ \\ $b_{i}$ \\ $B$ \\ $C_{m}$ \\ CV \\ $\langle C V\rangle$ \\ $C V_{u}$ \\ $E_{\text {global }}$ \\ $E_{\text {ref }}$ \\ $E_{\text {ref }}(\lambda)$ \\ $E_{\text {ref }}(\lambda, \theta, \phi)$ \\ $E_{s}(\lambda)$ \\ $E_{s}(\lambda, \theta, \phi)$ \\ $E_{\text {rot }}$ \\ FF \\ $I_{\text {diff }}$ \\ $I_{d i r}$ \\ $I_{\text {horrionat }}$ \\ $I_{\max }$ \\ $I_{s c}$ \\ $I_{s c}^{T, C}$ \\ $I_{s e}^{T, R}$ \\ $I_{s C}^{T, S}$ \\ $I_{s, R}^{R}$ \\ $I_{s c}^{R, S}$ \\ solar incidence angle, plane-of-measurement normal to sun angle \\ direction in which the plane is rotated, measured from $\gamma=0$ at due south \\ solar zenith angle \\ sensitivity coefficient \\ wavelength \\ ground albedo (reflected ground radiation / incident ground radiation) \\ standard deviation \\ solar azimuth angle, positive to the east of south, zero for south-facing \\ tilt angle of the plane as measured from a horizontal surface \\ bias limit for error source $i$ (Eq. 2-2) \\ total bias limit (Eqs. 2-1, 2-2) \\ pyranometer global-horizontal output voltage \\ PV calibration value under standard test conditions \\ mean calibration value \\ uncorrected calibration value \\ total global irradiance on a horizontal surface (Eqs. 2-8, 2-10) \\ reference total irradiance ( $1000 \mathrm{Wm}^{-2}$ for global) (Eq. 2-6) \\ reference spectral irradiance $\left(\mathrm{Wm}^{-2} \mu \mathrm{m}\right)$ (Eqs. 2-8, 2-10) \\ reference spectral irradiance with angularly resolved diffuse component \\ source spectral irradiance (Eqs. 2-8, 2-10) \\ angularly resolved spectral irradiance (Eq. 2-9) \\ total irradiance in the plane-of-measurement ( Eqs. 2-9, 2-10) \\ fill factor $\left(V_{o c}^{*} I_{s c} / P_{\max }\right)$ \\ total irradiance of the diffuse component on a horizontal surface \\ direct normal total irradiance \\ the total irradiance on a horizontal surface \\ current at the maximum power point \\ short-circuit current of a PV device \\ test cell short-circuit current corrected to reference total irradiance $E_{\text {ref }}$ \\ test cell short-circuit current under standard reporting conditions \\ test cell uncorrected short-circuit current under source irradiance \\ reference cell short-circuit current under standard reporting conditions \\ reference cell uncorrected short-circuit current under source irradiance
}


$k$

$M$

$L$

$P_{\text {max }}$

$R$

$R T D$

$r_{i}$

$S_{r}(\lambda)$

$S_{r}(\lambda, \theta, \phi)$

$t_{95}$

$T_{\text {coef }}$

$T_{m}$

$U_{95}$

$V_{\max }$

$V_{o c}$ spectral correction factor (Eqs. 2-9, 2-10, Appendix A)

spectral mismatch error (Eq. 2-8)

solar elevation angle

maximum generated electrical power

total precision index or random error (1 standard deviation) (Eqs. 2-1, 2-2)

resistance temperature detector

precision index or random error for error source $i$ (Eq. 2-3)

PV spectral response ( $\mathrm{AW}^{-1}$ ) (Eqs. 2-8, 2-10)

PV spectral response including angular dependence (Eq. 2-9)

Student's t-value for $95 \%$ confidence (Eq. 2-1)

temperature coefficient normalized to $25^{\circ} \mathrm{C}$ (ppm per ${ }^{\circ} \mathrm{C}$ ) (Eq. 3-1)

measured temperature (Eq. 3-1)

uncertainty interval that is expected to include $95 \%$ of all results (Eq. 2-1)

voltage at the maximum power point

open-circuit voltage 
TR-213-3472 


\subsection{INTRODUCTION}

\subsection{Purpose}

This report documents the SERI results from the Photovoltaic Solar Energy Project (PEP) 1987 Summit Round Robin. At the fourth joint coordination meeting of the PEP summit group held at Horben / Freiburg F.R. Germany on November 6-7, 1986, the participants decided to conduct an intercomparison of PV cells in single-cell and multiple-cell packages and modules. The organizing agent for this intercomparison was Dr. J. Metzdorf of Physikalisch-Technische Bundesanstalt (PTB) of the Federal Republic of Germany. A meeting of experts from the participating countries was held in February 1987 to establish the objectives. The stated objectives were

1. "To examine whether the calibration methods as described in the draft IEC TC82 (Secretariat) 24 a document [Table $A-1]$ are suitable for wide use at laboratory and industrial levels and future international standardization."

2. "To study the definition and packaging of reference devices. Each reference device should be representative of the technology of the associated module."

3. "To establish the performance measurement methods for solar modules and compare results obtained."

The purpose of this report is to (hopefully) fulfill the objectives of the intercomparison, to compare several of the various PV calibration methods, and to document the SERI PEP ' 87 results. The calibration methods that are compared in this study are the global method with a south-facing fixed-tilt, the global method with normal incidence, the SERI direct-normal method, and the National Aeronautics and Space Administration's (NASA) high-altitude aircraft AM0 method. This report discusses the uncertainties, advantages, and limitations of these methods. Particular attention is given to the IEC global calibration method and its various constraints and options. The merits and problems associated with the various reference device package designs are also discussed.

\subsection{Organization of Report}

This report is divided into five sections: an introduction, $\mathrm{PV}$ and radiometer calibration methods with an uncertainty analysis, results of SERI's participation in the PEP '87 intercomparison, a discussion of the PV calibration methods based on the data in this report, and a summary with several recommendations. Appendix A gives the International Electrotechnical Commission (IEC) proposed global calibration method and the global reference spectrum. The data sheets requested by the organizing agent are contained in Appendix B, and Appendix C contains the uncorrected global fixed-tilt and Spire SPI-SUN Model 240 Simulator measurements. 


\subsection{Background of the Reference Cell Method}

The current-versus-voltage ( $I-V$ ) characteristics of a photovoltaic (PV) device are a function of the total irradiance and its spectral content, and temperature. The standard reporting conditions for terrestrial nonconcentrating measurements ( $I-V$ and efficiency) are defined by a reference spectral irradiance (Table A-2), total irradiance $\left(1000 \mathrm{Wm}^{-2}\right)$, temperature $\left(25^{\circ} \mathrm{C}\right)$, and a standard definition of area. The total irradiance of the solar simulator or natural sunlight is measured with a reference device, either thermal or photovoltaic. For simulator-based measurements, the simulator is adjusted until the short-circuit current of the reference cell is equal to its calibrated value. For outdoor measurements the total irradiance can be measured with a PV reference device (a cell, a cell in a module package, or a module) or pyranometer. Natural or simulated sunlight will never equal the global reference spectrum in Table A-2; hence, a spectral mismatch error will always exist. The reference cell method minimizes this spectral mismatch error by requiring that the spectral response of the reference device "match" the spectral response of the device under test. Section 2.6.3 describes how the requirement for a matched reference cell can be relaxed by correcting for the spectral mismatch error. For outdoor measurements in which performance under actual operating conditions is desired, a PV reference device may not be desirable because it is inappropriate to correct the data for spectral mismatch. A thermopile reference detector whose spectral response is independent of wavelength is better suited for such measurements.

A wide variety of calibration methods are available with a range of merits and problems. One of the purposes of this report is to compare several of the more popular methods. In choosing the most applicable PV calibration method, one should consider the following options: total measurement uncertainty (random plus nonrandom error), cost (equipment, development time), time required to obtain the calibration value, and generality (applicability to any device of any size). There is certainly no single method that satisfies all of these requirements; therefore, the selection should be based on the needs of both the calibration laboratory and the end users. The physical design of a PV reference device requires parameters such as stability, susceptibility to damage, cost, ease of use, size, field-of-view, and internal reflections. As in the case of PV calibration methods, no single package design will be most appropriate. The goal should be to reach a compromise on the most meaningful and efficient package design(s) and calibration method(s). 


\subsection{MEASUREMENT PROCEDURES AND UNCERTAINTY ANALYSIS}

All measurements have errors. These errors are the differences between measured and true values. Measurement uncertainty analysis provides an estimate of the interval about the measured value of a quantity within which the true value is expected to lie. The purpose of uncertainty analysis is to identify the limitations and advantages of a measurement procedure, and PV calibration procedures presently in use cannot be compared reliably without using uncertainty analyses. An uncertainty. analysis should be performed before measurements are taken, in order that deficiencies in the measurement procedure can be identified and corrected. The first step in an uncertainty analysis is to carefully define the measurement procedure and the list all of the possible sources of bias (nonrandom) and precision (random) error. Guidance for identifying and estimating individual sources of error can be found in References $2-4$, which document the standard uncertainty analysis method. The elemental error sources can then be combined to obtain a total bias limit and precision index, as described in Section 2.1.

\subsection{Uncertainty Formulation}

The uncertainty formulation used in this section is based on the standard method described in References 2-4. The method separates each elemental error source $i$ into two components: a nonrandom or bias component $b_{i}$, and a random or statistical component $r_{i}$. Using this method, the uncertainty interval which is expected to include $95 \%$ of all results can be written as

$$
U_{95} \equiv \sqrt{B^{2}+\left(t_{95} * R\right)^{2}}
$$

with the total bias limit given by

$$
B \equiv \sqrt{\sum_{i=1}^{J}\left(\Theta_{i} * b_{i}\right)^{2}}
$$

and the total random error or precision index given by

$$
R \equiv \sqrt{\sum_{i=1}^{J}\left(\Theta_{i} * r_{i}\right)^{2}}
$$

where $t_{95}$ is the Student's $t$-value for $95 \%$ confidence and $J$ is the total number of elemental error sources. The random component is taken to be the standard deviation, which assumes that the random 
errors are Gaussian. For this work, the sensitivity coefficient $\Theta_{i}$ is assumed to be unity, and the elemental error sources are expressed as a percentage, while the degrees of freedom are all assumed to be greater than 30 , giving $t_{95} \approx 2$. For simplicity, all error sources are assumed to be independent of each other and symmetric about zero, even though this may not be true.

\subsection{Primary Absolute Cavity Radiometer}

The international reference standard for broadband solar radiometry is the World Radiometric Reference (WRR) defined by the World Meteorological Organization (WMO). The absolute uncertainty in the WRR quoted by WMO is $\pm 0.30 \%$ [5].

SERI maintains direct traceability for its primary absolute cavity radiometers (TMI-68018 and TMI-67814) through periodic international intercomparisons sponsored by. WMO [5]. The uncertainty limit for SERI's cavity radiometers is $\pm 0.45 \%$ (there is a $95 \%$ probability that the measured value lies within this range) with an estimated bias error of $0.37 \%$, and a total random error $R$ of $0.13 \%[6]$.

\subsection{Global Pyranometer Calibration}

The pyranometers used for the intercomparison were calibrated at the SERI South Table Mountain test site using the global-horizontal method on the roof of a building with an unobstructed $180^{\circ}$ field-of-view (FOV). Figure $2-1$ is a photograph of the pyranometer calibration facility.

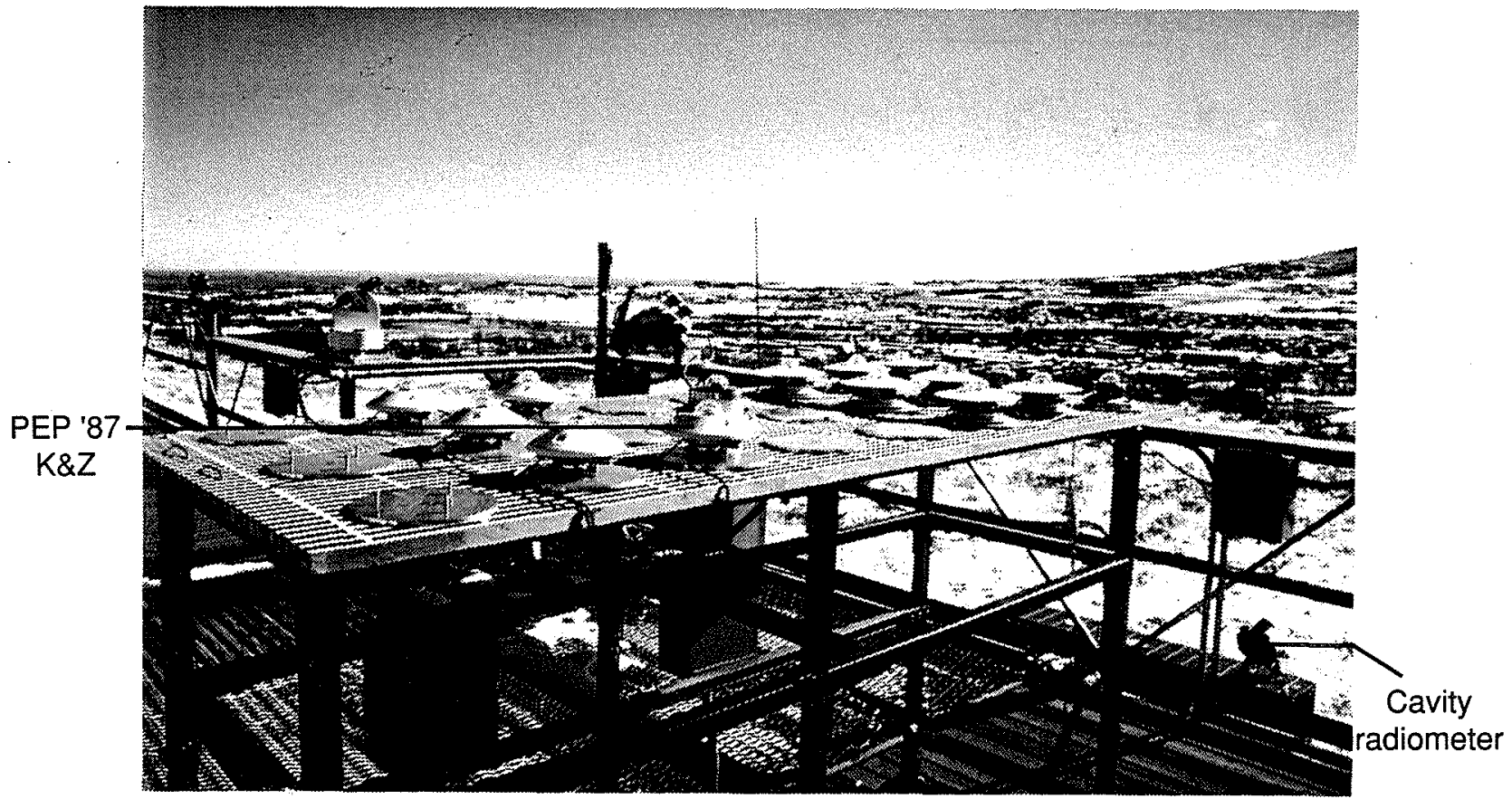

Figure 2-1. Pyranometer Calibration Site 
The pyranometer calibration factor $C_{f}\left(\mathrm{mVkW}^{-1} \mathrm{~m}^{2}\right)$ is calculated as follows $[6,7]$ :

$$
C_{f}=\frac{C_{m}}{I_{d i r} * \cos (\theta)+I_{d i f f}}
$$

where $C_{m}$ is the global-horizontal voltage output from the pyranometer to be calibrated, $I_{d i r}$ is the total irradiance measured with a primary absolute cavity radiometer $\left(5^{\circ} \mathrm{FOV}\right), \theta$ is the zenith angle, and $I_{\text {diff }}$ is the total irradiance of the diffuse component measured by a horizontal pyranometer with a shading disk. This method is often refered to as the component summation method. The three parameters, $C_{m}, I_{d i f}$, and $I_{d i r}$, are measured over a range of zenith angles on at least two days. The direct component during calibrations must be more than $80 \%$ of the total global irradiance, or

$$
\frac{I_{\text {dir }} * \cos (\theta)}{I_{\text {horizontal }}}>0.8
$$

where $I_{\text {horizontal }}$ is the total irradiance on a horizontal surface. For all pyranometer calibrations reported here, there were no clouds within $30^{\circ}$ of the sun.

A summary of the elemental error sources and the $U_{95}$ uncertainty limit for primary pyranometer calibrations performed at SERI is given in Table 2-1 [6]. Because of the way in which error sources combine, an uncertainty limit of $\pm 2.9 \%$ indicates that PV calibrations employing a pyranometer for total irradiance measurements must have an uncertainty limit greater than $\pm 2.9 \%$.

Table 2-1. $U_{95}$ Pyranometer Calibration Uncertainty

\begin{tabular}{lccc}
\hline \multicolumn{1}{c}{ Source } & $\begin{array}{c}\text { Bias } \\
(\%)\end{array}$ & $\begin{array}{c}\text { Random } \\
(\%)\end{array}$ & $\begin{array}{c}\text { Total }\left(U_{95}\right) \\
(\%)\end{array}$ \\
\hline Cavity radiometer & 0.37 & 0.13 & 0.45 \\
Diffuse pyranometer & 0.42 & 0.19 & 0.57 \\
Data acquisition & 0.12 & 0.02 & 0.13 \\
Incidence angle determination & 1.00 & 0.20 & 1.08 \\
Cosine response & 1.00 & 0.50 & 1.41 \\
Azimuth response & 1.00 & 0.50 & 1.41 \\
Temperature response & 1.00 & 0.50 & 1.41 \\
Linearity & 0.10 & 0.10 & 0.22 \\
Spectral response & 0.15 & 0.15 & 0.33 \\
Thermal voltages & 0.10 & 0.10 & 0.22 \\
Time constants & 0.10 & 0.10 & 0.22 \\
Thermal gradients & 0.30 & 0.10 & 0.36 \\
\hline Total & & & \\
\hline
\end{tabular}


Because a single pyranometer calibration number $C_{f}$ is appropriate for most applications, the error components listed in Table 2-1 cannot be reduced appreciably. Plots of calibration factor versus zenith angle, along with the calibration factor for the pyranometers used in this study, are given in Figures 2-2 to 2-7. Several of the plots (Figures 2-2 to 2-5) have two distinct curves; one curve is for morning data and the other curve is for afternoon data, signifying a sensitivity to both the zenith and azimuth angles of the incident sunlight and possibly to temperature. Any pyranometer (even if "temperature-compensated") has a unique temperature coefficient that is difficult to measure. Because other participating laboratories have also calibrated the PEP ' 87 Kipp and Zonen CM11-4 pyranometer (see Figure 2-2 and Table B-1), an uncertainty in the calibration value will exist due to the wide range of temperatures that this pyranometer encounters. Figure 2-8 shows the calibration value of the PEP ' 87 pyranometer as a function of body temperature, while Figure 2-9 illustrates the variability typical of temperature coefficient determinations for Kipp \& Zonen pyranometers [9]. The calibration factor of the PEP '87- pyranometer reported in Table B-1 accounts for the temperatures encountered at SERI during the PEP ' 87 intercomparison. Other participants who have calibrated and used this pyranometer undoubtedly encountered different temperatures. Because of this substantial temperature coefficient, the $\sim 20^{\circ} \mathrm{C}$ body-temperature data were used to calculate the calibration factor used in this study (Figures 2-2 and 2-5).

\subsection{Spectroradiometers}

SERI spectroradiometric calibrations and solar spectral irradiance measurements are directly traceable to the United States National Institute of Standards and Technology (formerly the National Bureau of Standards) spectral irradiance scale [9]. The total uncertainty limit $U_{95}$ for the standard lamp used to calibrate the spectroradiometer is $4.6 \%$ at $300 \mathrm{~nm}, 4.4 \%$ at $650 \mathrm{~nm}, 3.7 \%$ at $1300 \mathrm{~nm}$, and $5.6 \%$ at $2000 \mathrm{~nm}[10]$.

The majority of the spectral irradiance measurements were performed using LI-COR LI-1800 spectroradiometers (spectral range $300-1100 \mathrm{~nm}, 2 \mathrm{~nm}$ wavelength increment) equipped with a temperature-controlled detector and a Teflon dome diffuser [11]. The monochrometer slits used resulted in a $2 \mathrm{~nm}$ full-width at half-maximum bandwidth. For the direct-normal outdoor calibrations, the LI-1800 was fitted with a collimating tube (direct-beam modute) to match the $5.0^{\circ}$ field-of-view of the TMI cavity radiometers, and for the global-normal measurements, a custom integrating sphere was attached to the LI-1800 unit in place of the Teflon dome to reduce cosine errors. The global fixed-tilt measurements used both an LI-1800 having the standard Teflon dome, and a second LI-1800 unit with the integrating sphere [12]. When the LI-1800 spectroradiometers are used outdoors, they are shielded with aluminum foil to prevent excessive heating of the unit's electronics, which causes a bias error in the spectral irradiance. An Optronics Laboratory Model $746 \mathrm{D}$ spectroradiometer was used to measure the spectral irradiance of the Spectrolab X25 solar simulator from 800 to $2000 \mathrm{~nm}$. The spectral irradiance of the Optronics unit was multiplied by a constant to force the irradiance integrated from 800 to $1100 \mathrm{~nm}$ to agree with the LI-1800 data integrated over the same range. 


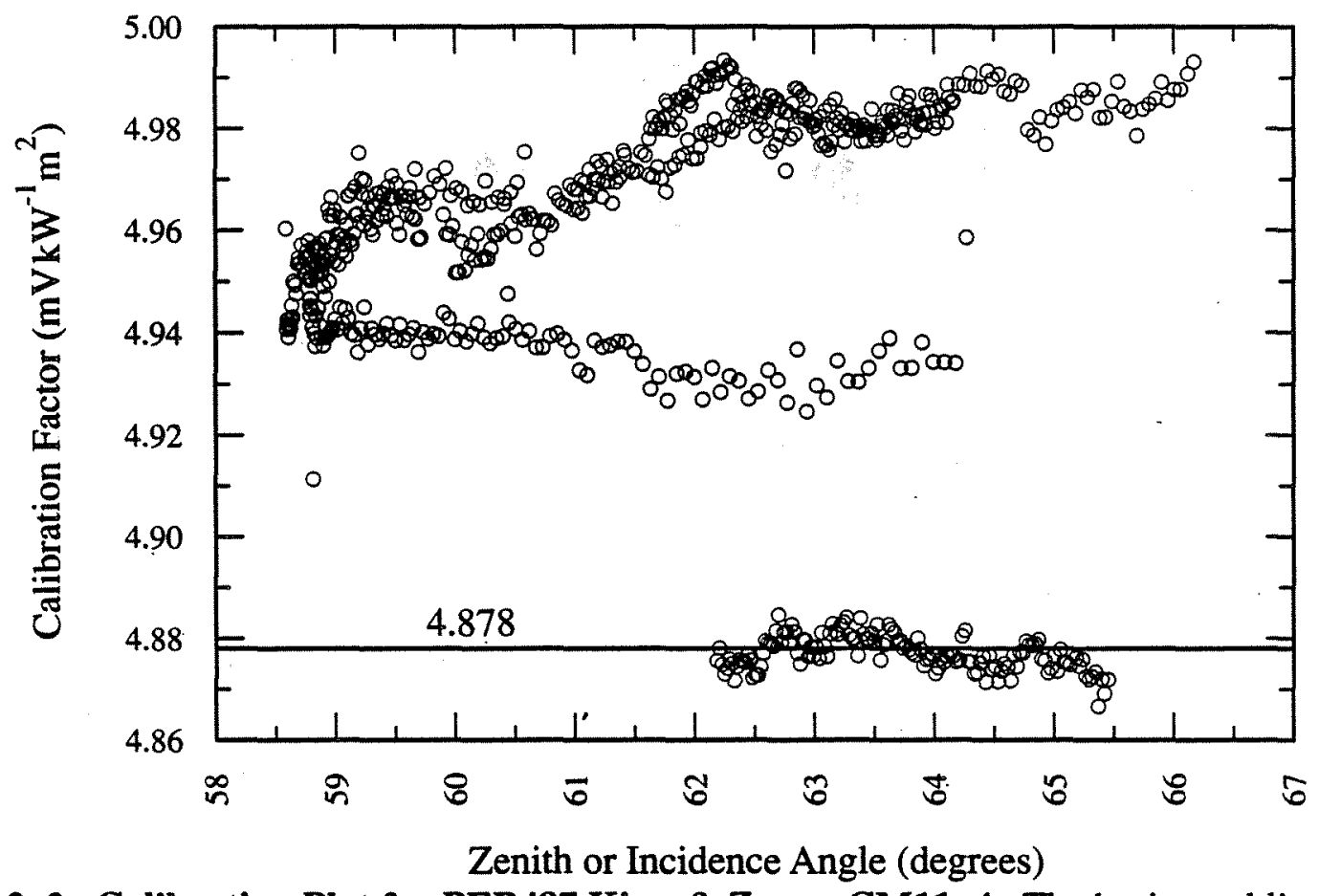

Figure 2-2. Calibration Plot for PEP '87 Kipp \& Zonen CM11-4. The horizontal line shows the $4.878 \mathrm{mVkW}^{-1} \mathrm{~m}^{2}$ calibration factor used for this study. Note that $1 / C_{f}$ is $205.0 \mathrm{Wm}^{-2} \mathrm{mV}^{-1}$.

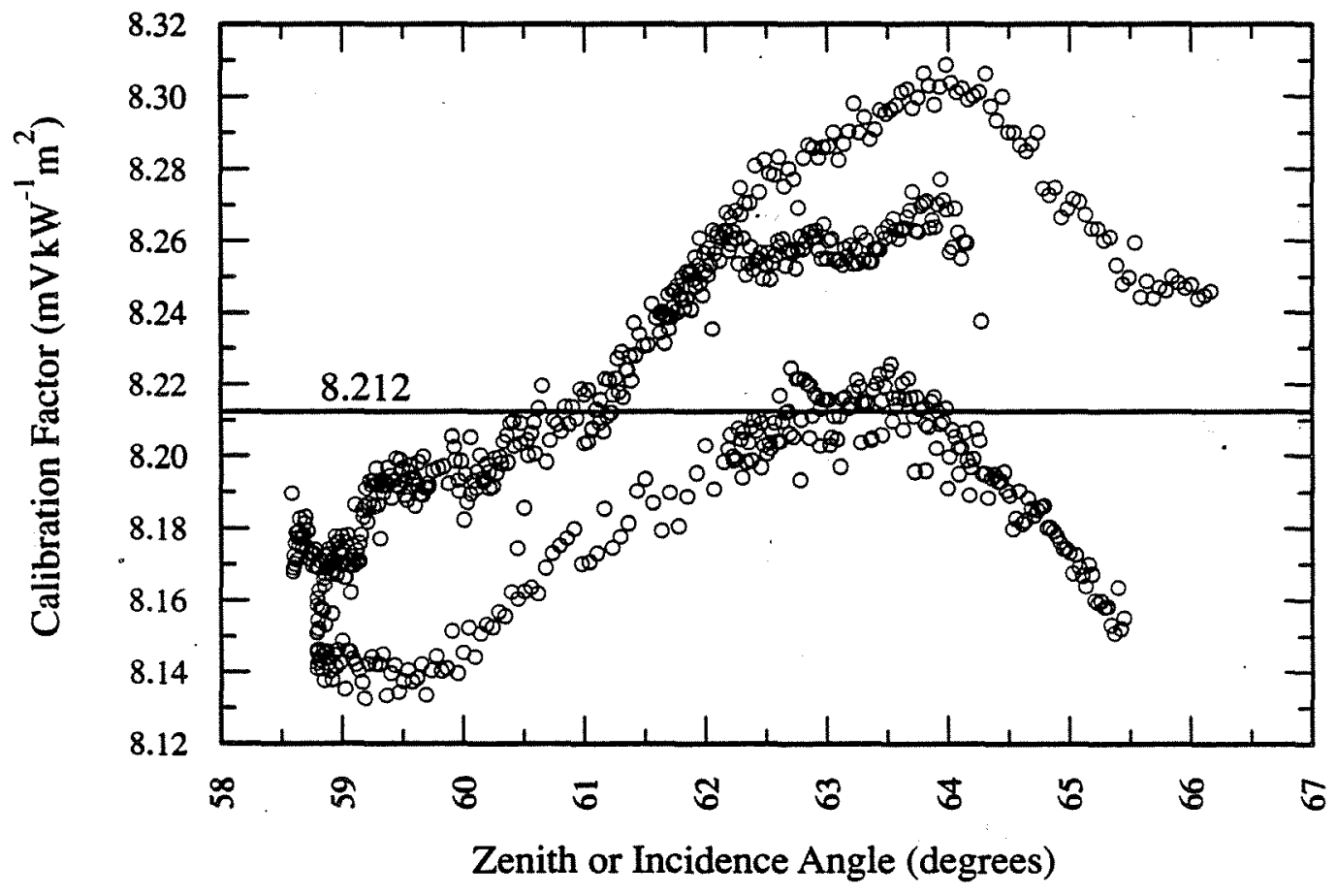

Figure 2-3. Calibration Plot for Eppley PSP 17863F3 Used for Global-Normal Diffuse Measurements 
TR-213-3472

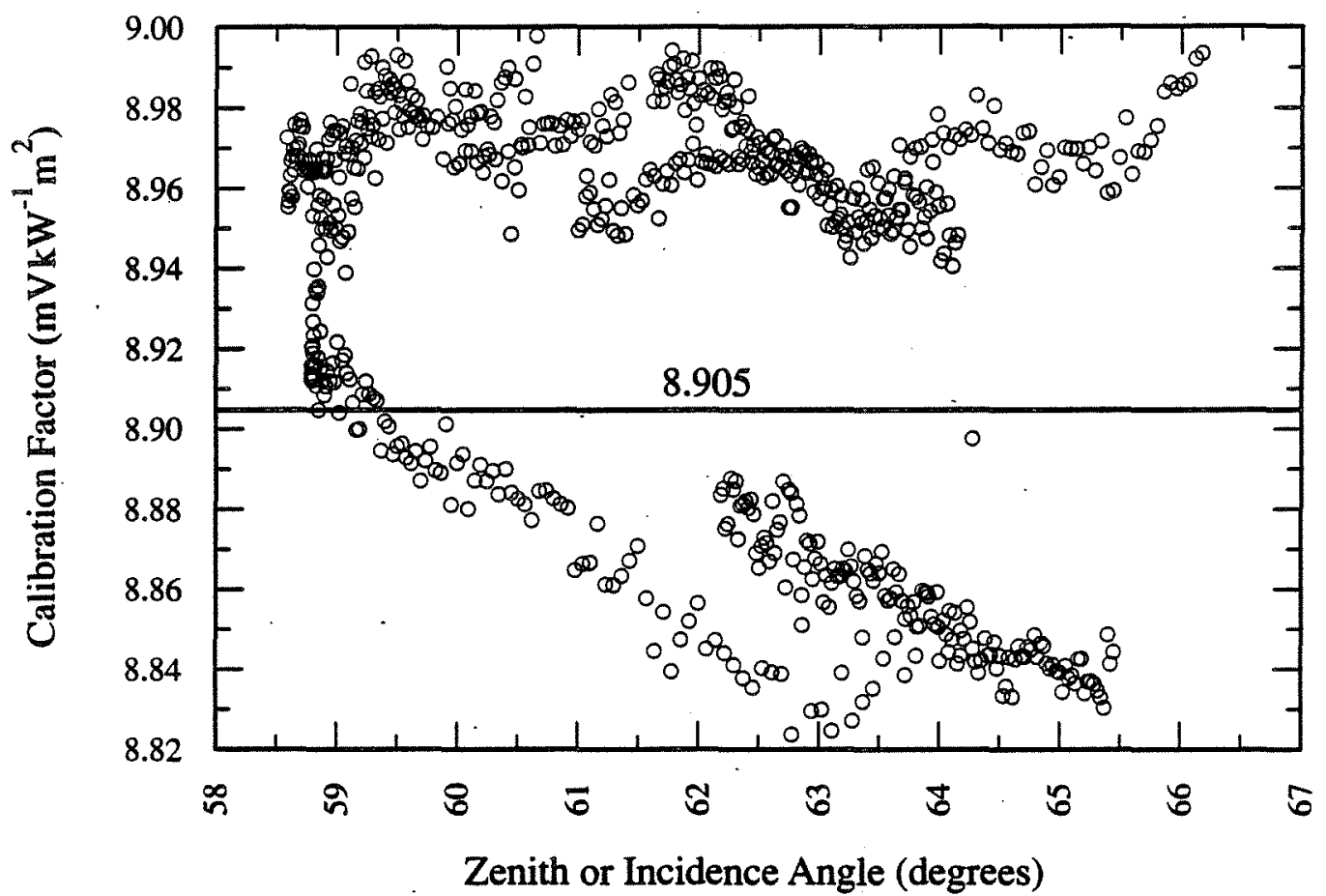

Figure 2-4. Calibration Plot for Eppley PSP 24191F3 Used for Global-Normal Measurements

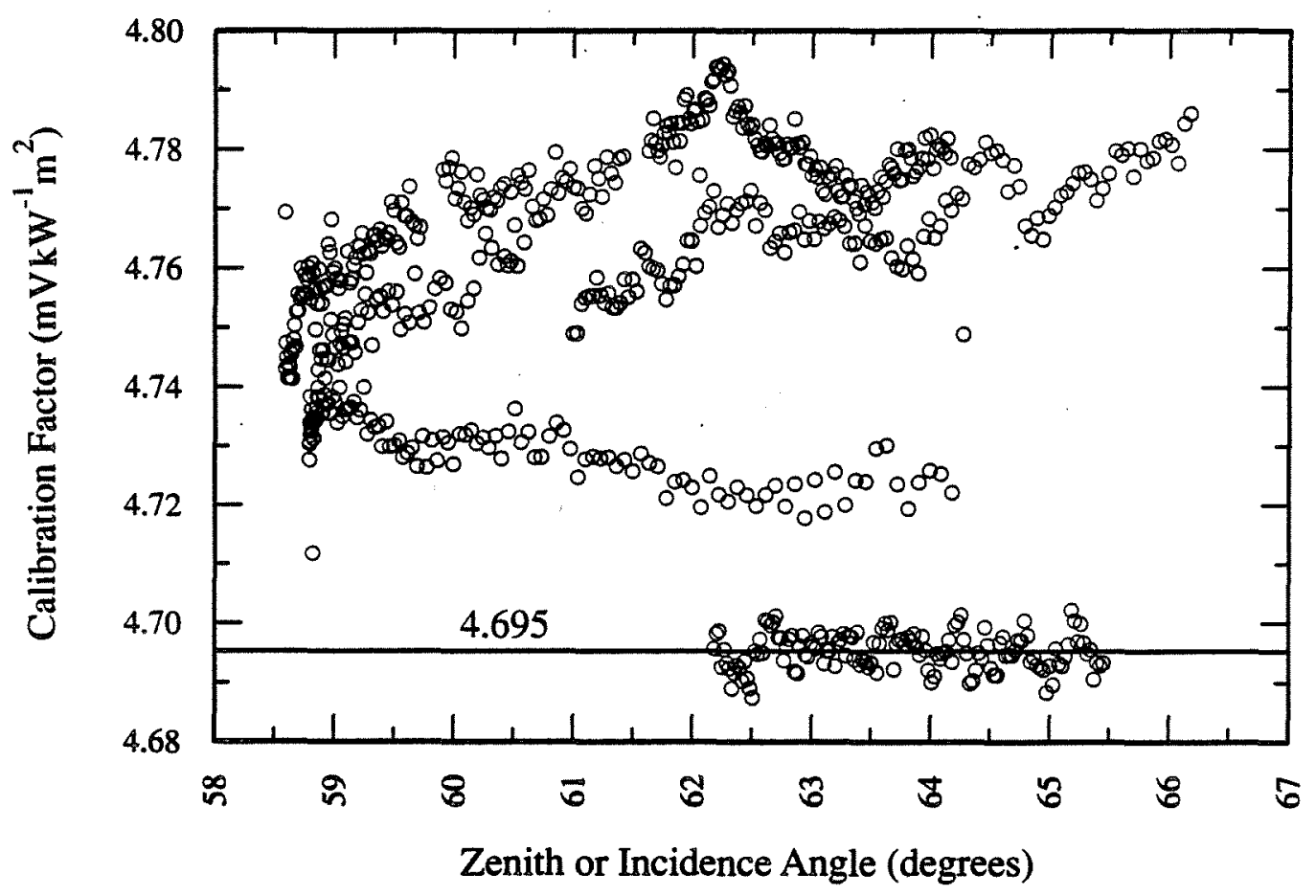

Figure 2-5. Calibration Plot for SERI Kipp \& Zonen CM11 830092 Used for Global-Normal Measurements 


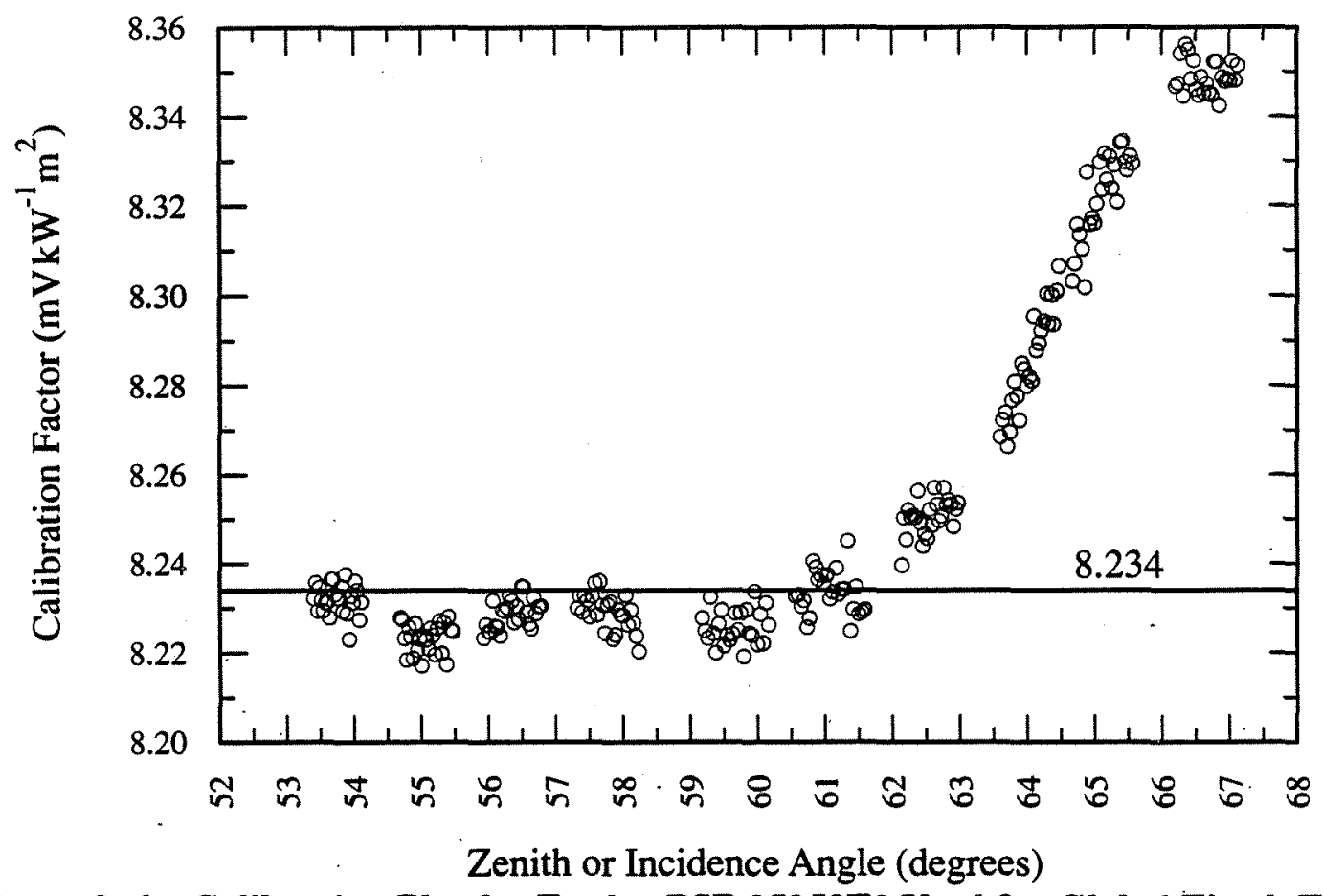

Figure 2-6. Calibration Plot for Eppley PSP 25952F3 Used for Global Fixed-Tilt Measurements

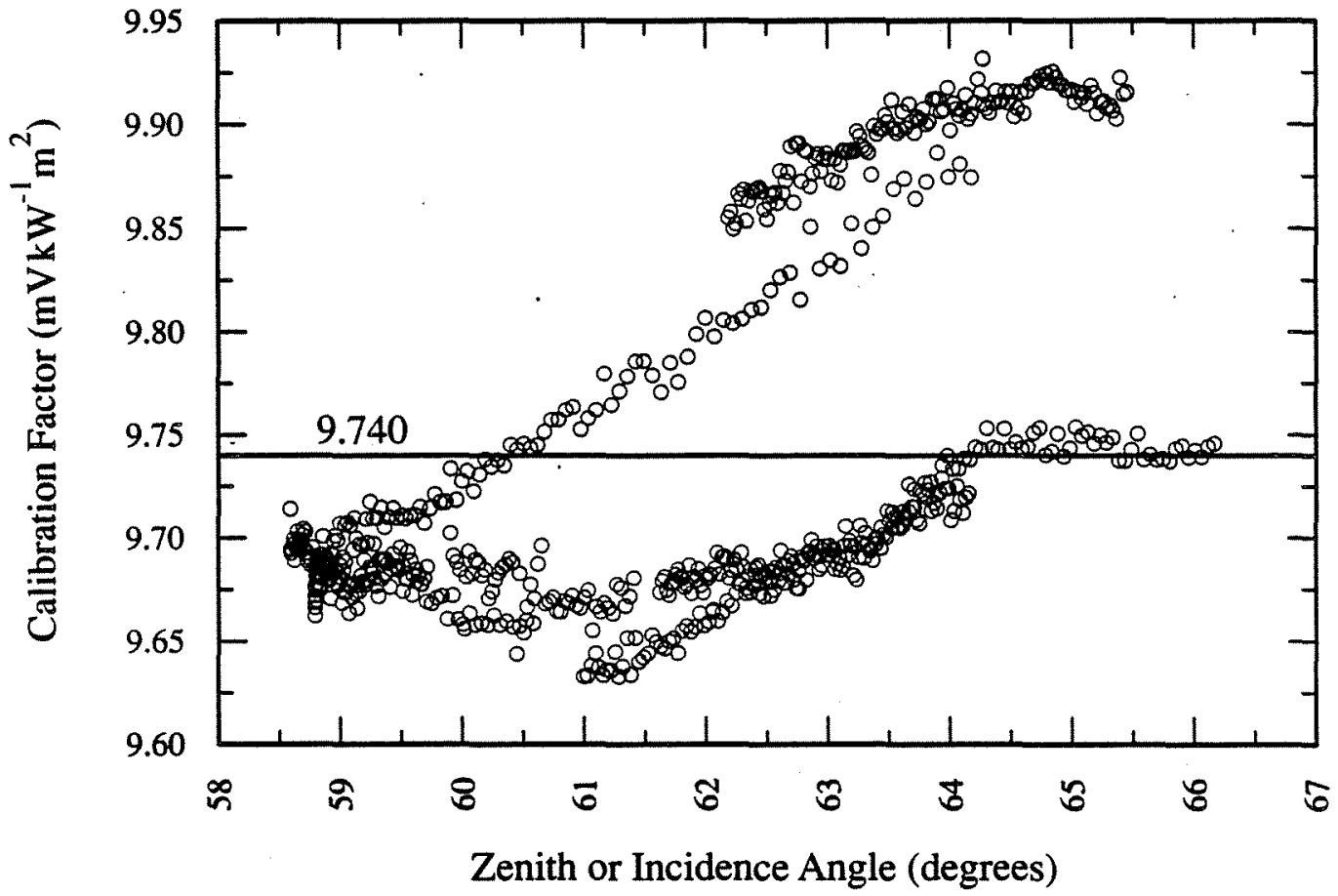

Figure 2-7. Calibration Plot for Eppley PSP 24034F3 Used for Global Fixed-Tilt Diffuse Measurements 


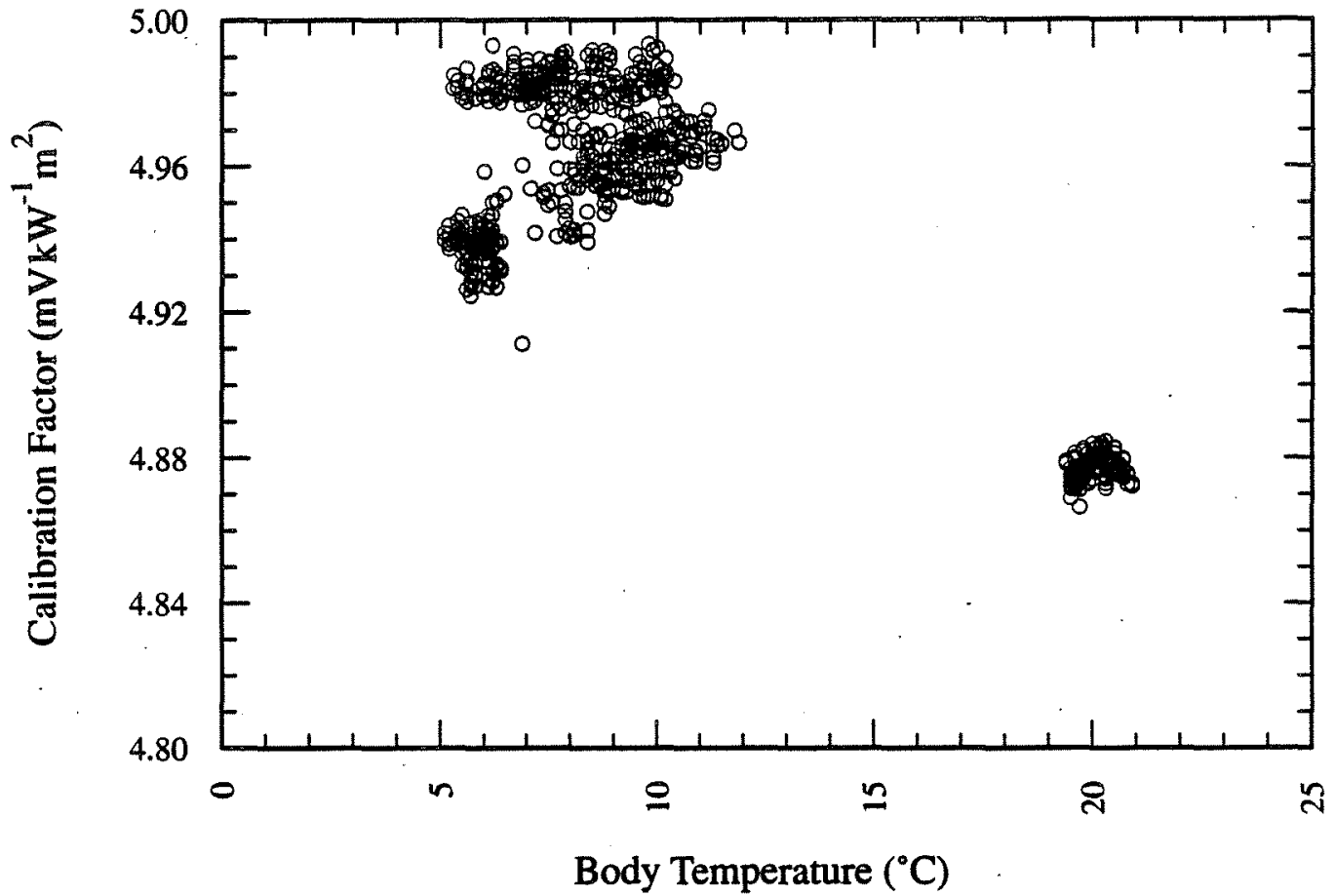

Figure 2-8. PEP '87 Kipp \& Zonen CM11-4 Calibration vṣ. Body Temperature

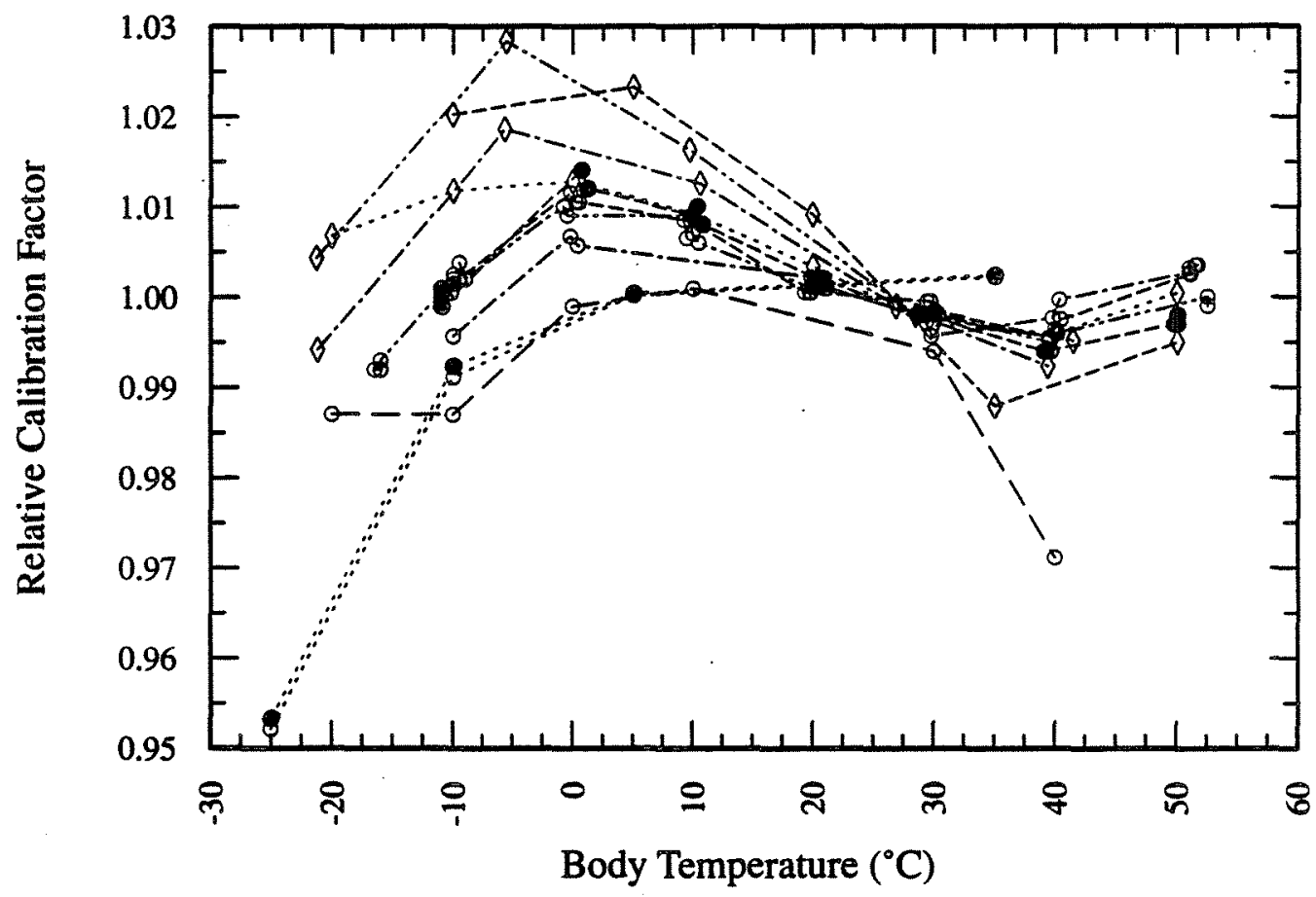

Figure 2-9. Temperature Response of Three Kipp \& Zonen CM11 Pyranometers Determined at Five Laboratories over a Four Year Period [9] 
The estimated uncertainty for the normal-incidence spectral irradiance measured with a LI-1800 spectroradiometer either with or without an integrating sphere is $\pm 20 \%$ for $300-400 \mathrm{~nm}, \pm 5 \%$ for $400-900 \mathrm{~nm}$, and $\pm 8 \%$ for $900-1100 \mathrm{~nm}$. However, the estimated uncertainty of the spectral irradiance for non-normal-incidence light becomes $\pm 20 \%$ for $300-400 \mathrm{~nm},+5$ to $-13 \%$ for $400-900 \mathrm{~nm}$, and +8 to $-15 \%$ for $900-1100 \mathrm{~nm}$.

The Teflon dome has a wavelength-dependent error of about $40 \%$ at $15^{\circ}$ incidence angle which is due to the wavelength-dependent transmission and dispersion [11]. There is an additional error due to a mirror under the Teflon dome that directs light to the entrance optics. Depending on the orientation, this error can be either negligible (long axis of the unit facing east-west) or large (long axis of the unit facing north-south). For these reasons, the LI-1800 spectroradiometer with a Teflon dome diffuser is used quantitatively only for normal-incidence light.

For direct-normal measurements, the measured spectral irradiance is extended using a radiative-transfer model to cover the range of the reference spectrum (305-4045 nm) [12]. The extension procedure does not require separate water vapor and turbidity determinations and is sufficiently accurate to identify drifts in the spectroradiometer calibration with air temperature even when the detector is temperature-controlled within $\pm 0.5^{\circ} \mathrm{C}$.

\subsection{Spectral Response}

The spectral response measurement system used in this study is based on a periodic light $(440 \mathrm{~Hz})$ directed through one of 51 narrow-bandwidth interference filters covering the spectral range from 300 to $2000 \mathrm{~nm}$. The system is capable of providing steady-state light bias levels up to $2 \mathrm{~A}$ and voltage bias levels from $0 \pm 1 \mathrm{mV}$ to $\pm 50 \mathrm{~V}$ (Figure 2-10) [13]. The bias light is normally adjusted to give the short-circuit current $I_{s c}^{T, C}$ from the following equation:

$$
I_{s c}^{T, C}=\frac{C V * E_{r e f} * I_{s c}^{T, S}}{I_{s c}^{R, S}}
$$

where $C V$ is the calibration value for the primary reference cell and $E_{\text {ref }}$ is the reference total irradiance (1000 Wm $\mathrm{Wm}^{-2}$ for global and $1367 \mathrm{Wm}^{-2}$ for AM0). $I_{s c}^{R, S}$ is the short-circuit current of the reference cell under the source (simulator) spectrum and $I_{s c}^{T, S}$ is the short-circuit current of the test cell under the source spectrum. The measured spectral response is normalized to integrate to the short-circuit current measured in the Spectrolab X-25 solar simulator and corrected for spectral mismatch [14-19] using

$$
I_{s c}^{T, R}=\frac{I_{s c}^{T, C}}{M}
$$




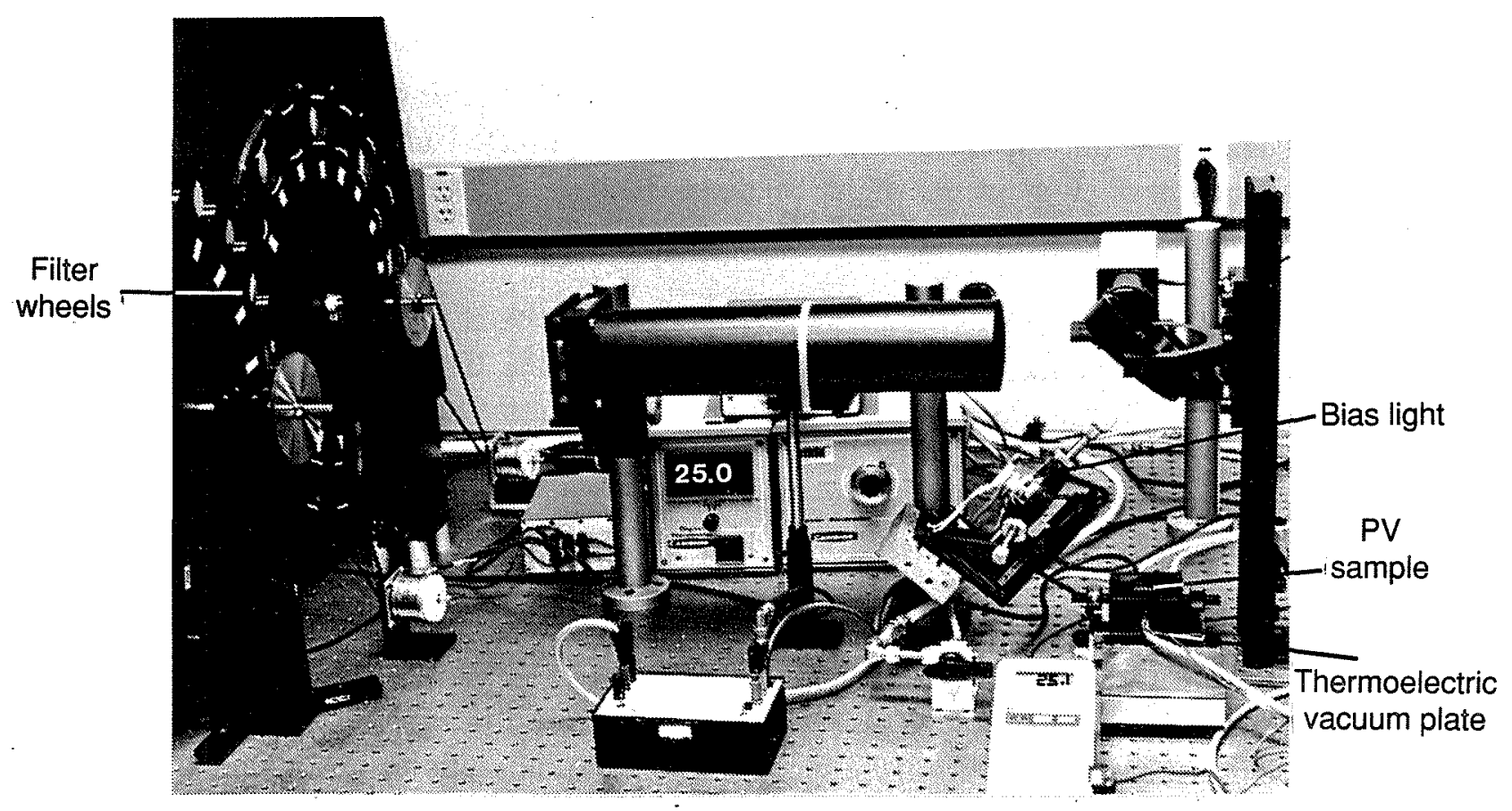

Figure 2-10. Photograph of the SERI Spectral Response Measurement System

where the spectral mismatch correction $M$ is given by

$$
M=\frac{\int_{\lambda 1}^{\lambda 2} E_{s}(\lambda) * S_{t}(\lambda) d \lambda}{\int_{\lambda 4}^{\lambda 4} E_{s}(\lambda) * S_{r}(\lambda) d \lambda} * \frac{\int_{\lambda 3}^{\lambda 4} E_{r e f}(\lambda) * S_{r}(\lambda) d \lambda}{\int_{\lambda 2}^{\lambda 2} E_{r e f}(\lambda) * S_{t}(\lambda) d \lambda}
$$

This method for absolute spectral response is used because the uncertainty in $I_{s c}^{T, R}$ is comparable to or lower than that which can be obtained using a calibrated reference photodiode to make the spectral response absolute [17]. This method is also not restricted to the narrow calibration range $(300-1100 \mathrm{~nm})$ of a silicon detector. The limits of integration on $M$ should cover the spectral response of the test cell $S_{t}(\lambda)$ and the reference cell $S_{r}(\lambda)$. The spectral irradiance of the reference spectrum is $E_{r e f}(\lambda)$ and the spectral irradiance of the source spectrum is $E_{s}(\lambda)$. The estimated wavelength independent bias limit for the absolute spectral response is 1.1\% (see Table 2-5) [18]. Based upon repeated spectral response measurements on the same sample over a period of 3 years, the random error is estimated to be $2.5 \%$. 


\subsection{PV Calibration Uncertainty}

\subsubsection{Global Calibration Methods}

Global calibration methods include horizontal, south-facing fixed-tilt (normal incidence at solar noon), and a tracking normal-incidence plane-of-measurement (see Table A-1) [20, 21]. The fixed-tilt and normal-incidence methods were used for the PEP ' 87 intercomparison.

The IEC (see Table A-2) or ASTM E 892 [22] reference spectrum represents the spectral irradiance on a $37^{\circ}$ south-facing tilted surface with a solar zenith angle of $48.19^{\circ}$ (AM1.5), a wavelength-independent ground albedo of 0.2 , clear sky conditions, and standard sea level temperature and pressure. The Monte-Carlo ray-tracing model that generated the global reference spectrum reduced the angular dependence of the spectral irradiance to a single value by multiplying by the cosine of the diffuse incidence angle [23]. Because the terrestrial spectral irradiance is a complicated function of both wavelength and angular position, the calibration value should be generalized to include both the zenith $(\theta)$ and azimuth $(\phi)$ angular distribution of the plane-of-measurement spectral irradiance and spectral response [14] as

$$
\begin{aligned}
& \lambda_{2} \theta_{2} \phi_{2} \\
& \iiint E_{r e f}(\lambda, \theta, \phi) * S_{r}(\lambda, \theta, \phi) d \lambda d \theta d \phi \\
& C V=\frac{I_{s c}^{R, S} * k}{E_{t o t}}=\frac{I_{s c}^{R, S}}{E_{t o t}} * \frac{\lambda_{1} \theta_{1} \phi_{1}}{\lambda_{2} \theta_{2} \phi_{2}} \\
& \iiint E_{r e f}(\lambda, \theta, \phi) d \lambda d \theta d \phi \\
& \lambda_{1} \theta_{1} \phi_{1} \\
& \lambda_{2}{ }_{2}{ }_{2}{ }_{2} \\
& \iiint E_{s}(\lambda, \theta, \phi) d \lambda d \theta d \phi \\
& \text { * } \frac{\lambda_{1} \theta_{1} \phi_{1}}{\lambda_{2} \theta_{2} \phi_{2}} \\
& \iiint E_{s}(\lambda, \theta, \phi) * S_{r}(\lambda, \theta, \phi) d \lambda d \theta d \phi \\
& \lambda_{1} \theta_{1} \phi_{1}
\end{aligned}
$$

The angular dependence of the spectral response can be assumed to be the same in the azimuthal and zenith directions, reducing the spectral response measurement problem to measuring the response as a function of incidence angle. The angular distribution of the diffuse spectral irradiance is difficult to measure or model [24]. Shimokawa, et al., [25] have shown that assuming an ideal cosine response for a PV device can lead to substantial errors. The field-of-view for $E_{t o t}, E_{s}(\lambda, \theta, \phi)$, and $I_{s c}^{R, s}$ must be identical, which is nearly impossible to achieve for a nonhorizontal measurement plane. The 
integration limits should encompass the entire field-of-view. It is assumed that the instrument used to measure $E_{\text {tot }}$ has an ideal cosine and azimuthal response, although Equation 2-9 can be further generalized to include these effects if the relative azimuth and zenith angular response are known. The terms containing $E_{\text {ref }}(\lambda, \theta, \phi)$ account for the angular dependence of the reference cell and the reference spectrum.

Figure 2-11 shows the position of the sun relative to a tilted plane-of-measurement. The solar elevation angle is $L$ (which is $90^{\circ}$ minus $\theta$, the zenith angle), and the azimuthal angle of the sun is $\phi$ (positive to the east and negative to the west if measured from the south). The angle $\Psi$ is the tilt angle of the plane as measured from a horizontal surface, and the angle $\gamma$ is the direction in which the plane is tilted, measured from $\gamma=0$ at due south and increasing as the plane-of-measurement rotates easterly. The incidence angle $\alpha$ is the angle between the normal to the plane-of-measurement and the sun vector; the incidence angle is the same as the zenith angle for horizontal surfaces.

The site for the fixed-tilt calibration is shown in Figure 2-12, and the plane-of-measurement is shown in Figure 2-13. The custom data-acquisition system [26] recorded for each data point the I-V curve for a single sample, two global spectral irradiances (measured using separate LI-1800 spectroradiometers with a Teflon dome and an integrating sphere), direct-normal, diffuse, and two plane-of-measurement global fixed-tilt irradiances, wind speed and direction, sample and air temperature, and the barometric pressure. Data were collected for each sample for three days with

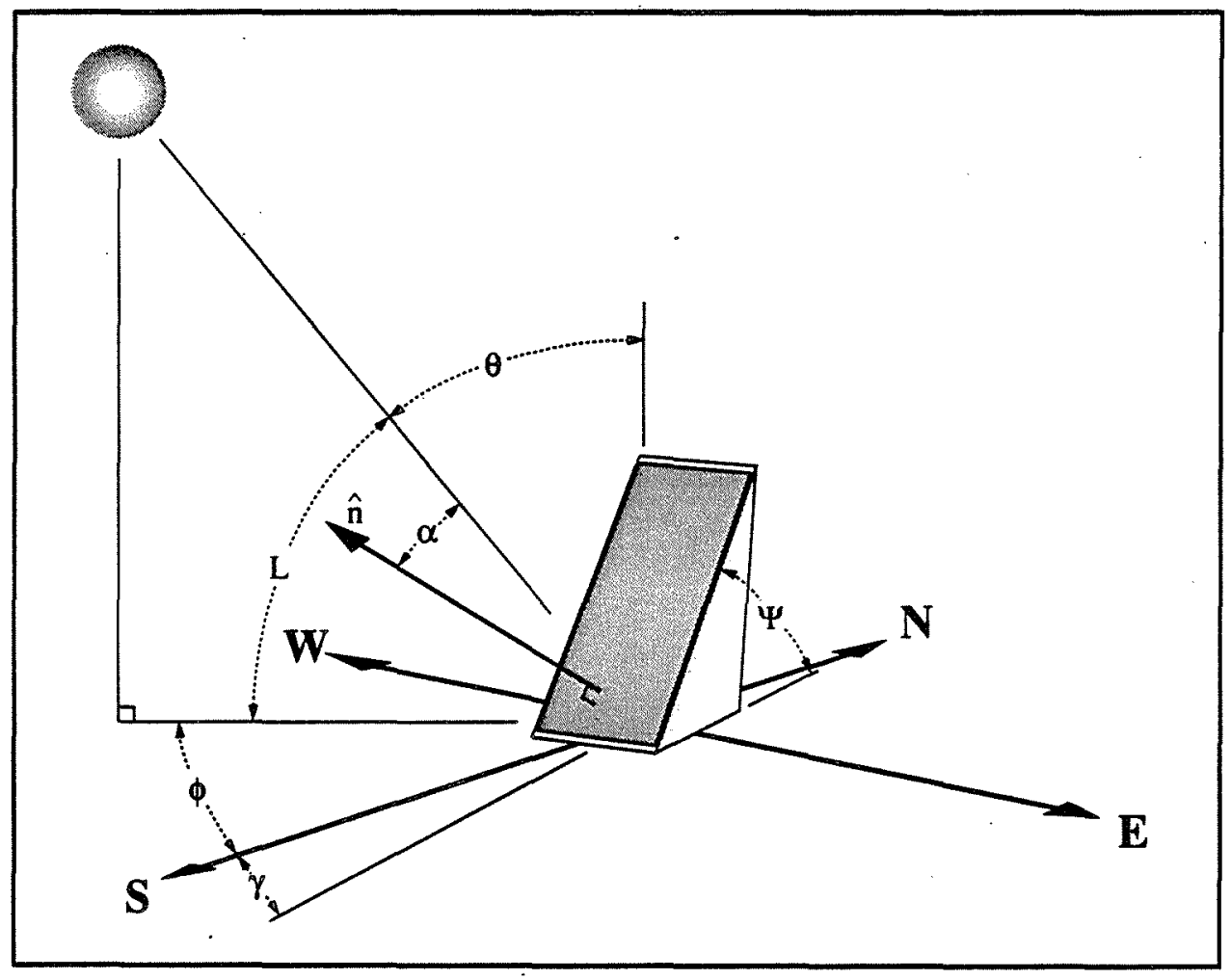

Figure 2-11. Solar Geometry Relative to the Plane-of-Measurement 
five to six points per day. An uncertainty analysis for this measurement system is shown in Table 2-2. The uncertainty analysis assumes that $E_{t o t}, E_{s}(\lambda, \theta, \phi)$, and $I_{s c}^{R, S}$ are measured at the same time, and that $I_{s c}^{R, S}$ is corrected for temperature to the $25^{\circ} \mathrm{C}$ reference temperature. It is also assumed that the spectral correction factor is applied. The pyranometer data were not corrected for temperature, and the direct-normal irradiance was greater than $80 \%$ of the total irradiance. Table 2-2 gives two $U_{95}$ totals. The first total is for $E_{t o t}$ measured with a pyranometer and the second total is for $E_{t o t}$ measured via the component summation technique using a cavity radiometer and a pyranometer equipped with a shading disk. The $2.1 \%$ estimated bias limit for a $3^{\circ}$ error in calculating the plane-of-measurement to sun angle is due to the difficulty in determining the actual PV tilt and orientation for the direct-plus-diffuse method of measuring $E_{t o t}$. If a pyranometer is used to measure $E_{t o t}$ this error occurs because the pyranometer bubble level and the sensor are not coplanar (estimated to be about $1^{\circ}$ ) and the bubble level is not exactly coplanar with the PV sample (about $2^{\circ}$ ).

The site used for the global-normal calibration measurements is shown in Figure 2-14, and the plane-of-measurement is shown in Figure 2-15. The data acquisition system for global-normal measurements consisted of an IBM PC controller, a Fluke 3421 40-channel data logger, and either load resistors $(0.01$ to $0.3 \Omega$ ) for most of the PV samples, or, for the amorphous and filtered silicon cells, an active load which biased the cells to within $1 \mathrm{mV}$ of $I_{s c}$. Global calibration data were collected on four days with 104 data points for each sample. The data logger recorded 30 readings for each data point, which were averaged at a later time. The measured data for each point included:

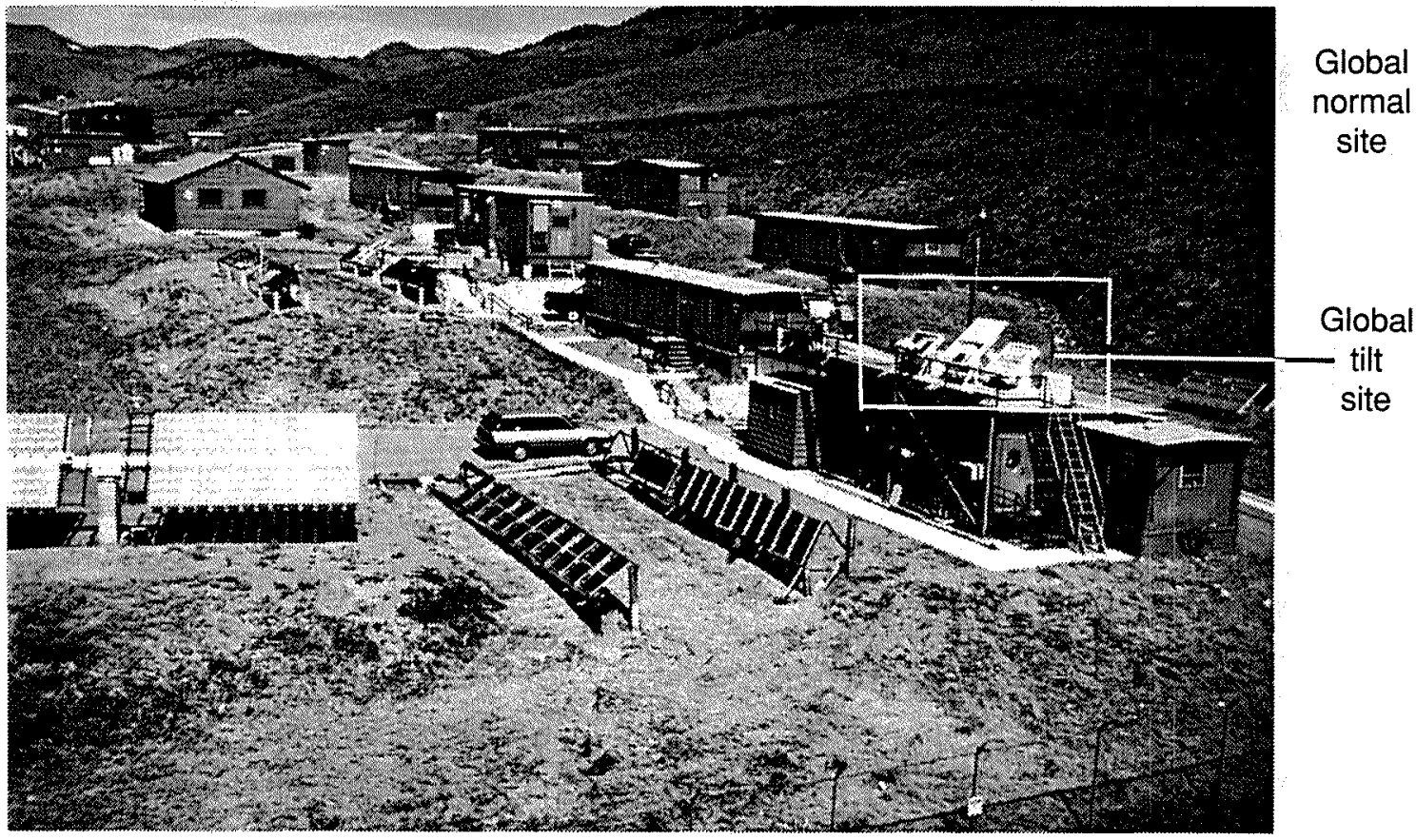

Figure 2-12. Photograph of the SERI Advanced PV Module Test Facility and the Global Fixed-Tilt Calibration Site 
global-normal spectral irradiance (LI-1800 with an integrating sphere), direct-normal, diffuse, global-horizontal, two plane-of-measurement global-normal irradiances, $I_{s c}$ for the PEP '87 samples RC -01 through RC-08, RM-03, RM-05, and three SERI reference cells, along with wind speed and direction, sample and air temperature, and the barometric pressure. The uncorrected calibration value $\left(C V_{U}=I_{s c} / E_{t o t}\right)$ was averaged from 30 readings over the $30 \mathrm{sec}$ period that the LI-1800 needs to measure the spectral irradiance. The other measured parameters (direct-to-diffuse ratio and barometric pressure) were also averaged over this time period for each of the 104 separate points. An uncertainty analysis for the global-normal incidence PV calibration method is given in Table 2-3. As in the global fixed-tilt case, the calibration value is assumed to be is corrected for temperature and spectrum to the reference conditions. The time constant error is slightly lower for the global-normal method compared to the global fixed-tilt method because of the 30 reading average for 30 seconds for each $C V_{U}$ point. Notice that this is not the average $I_{s c}$ divided by the average $E_{t o t}$. The random error for both the global fixed-tilt and the global-normal method is the same; however, the global-normal method has a lower bias error because of the reduced sensitivity to differences in pointing between the PV sample, the instrumentation used to measure $E_{\text {tot }}$, and the sun position. The bias error is lower for methods that use a primary absolute cavity radiometer to measure the direct component of $E_{\text {tot }}$ instead of a pyranometer, but the random error is similar. The results of the intercomparison reflect these differences, because the standard deviations were not appreciably different for the various global calibration methods.

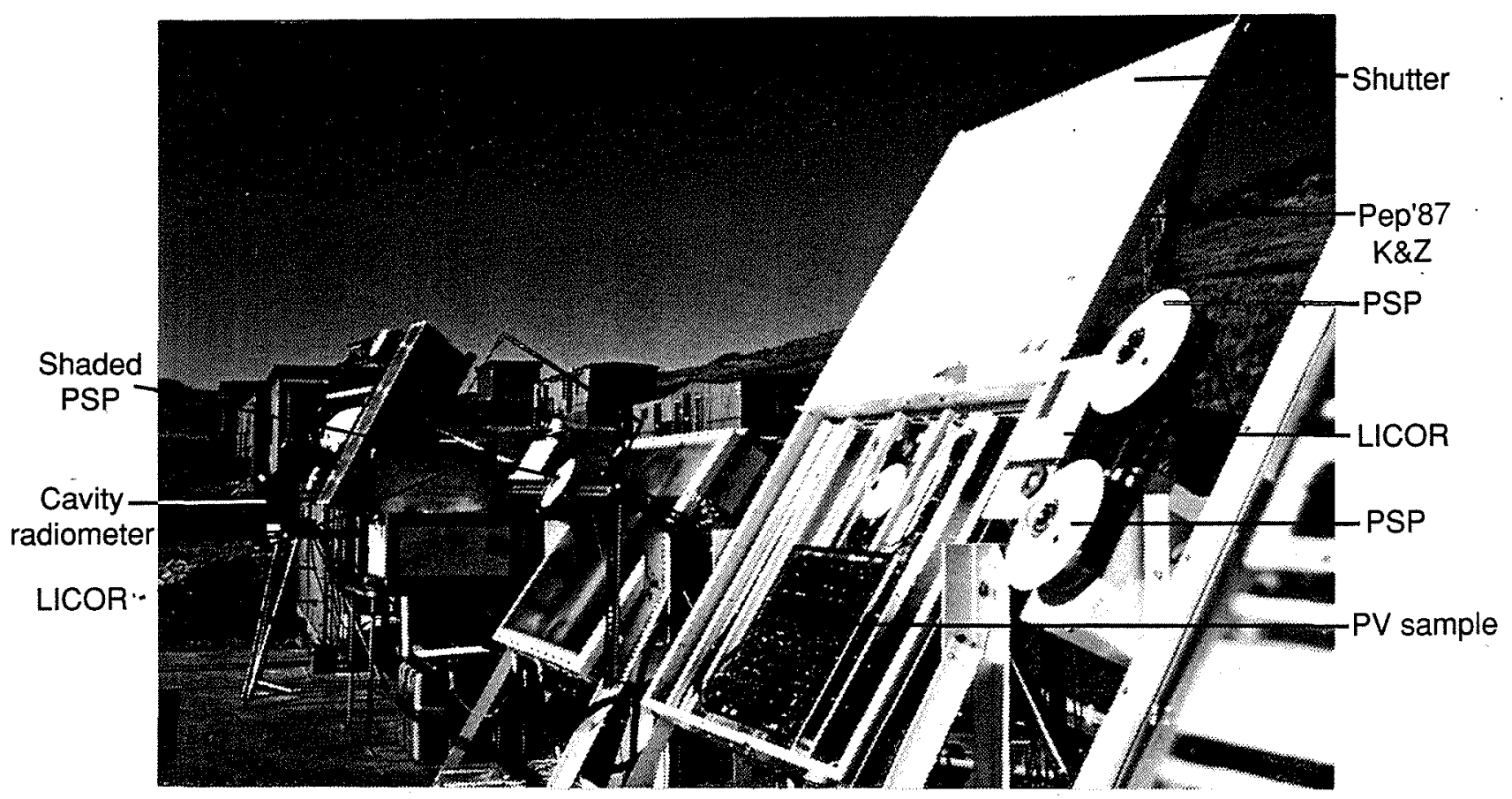

Figure 2-13. Sample Mounting Detail for Global Fixed-Tilt Calibrations 
Table 2-2. Global Fixed-Tilt $U_{95}$ Calibration Uncertainty

\begin{tabular}{lccc}
\hline \multicolumn{1}{c}{ Source } & $\begin{array}{c}\text { Bias } \\
(\%)\end{array}$ & $\begin{array}{c}\text { Random } \\
(\%)\end{array}$ & $\begin{array}{c}\text { Total }\left(U_{95}\right) \\
(\%)\end{array}$ \\
\hline$I_{s c}$ Kipp and Zonen CM11 pyranometer & 0.10 & 0.05 & 0.14 \\
$E_{t o t}$ cavity radiometer + shaded pyranometer & 2.12 & 0.95 & 2.85 \\
$E_{t o t}$ pointing or leveling error for $20^{\circ}$ incidence $\angle$ & 0.59 & 0.24 & 0.71 \\
Spectral correction & 2.08 & - & 2.08 \\
Deviation from ideal cosine response & 0.20 & 0.50 & 1.02 \\
PV temperature correction & 0.20 & - & 0.20 \\
PV $I_{s c}$ linearity & 0.15 & 0.10 & 0.25 \\
Thermal voltages & 0.05 & 0.05 & 0.11 \\
Time constants & 0.05 & 0.05 & 0.11 \\
Field-of-view and ground reflections & 0.50 & 0.10 & 0.54 \\
\hline Total $\left(E_{\text {tot }}\right.$ from pyranometer) & 0.50 & 1.00 & 2.06 \\
Total ( $E_{\text {tot }}$ from cavity radiometer + pyranometer) & 2.29 & 1.16 & 3.24 \\
\hline
\end{tabular}

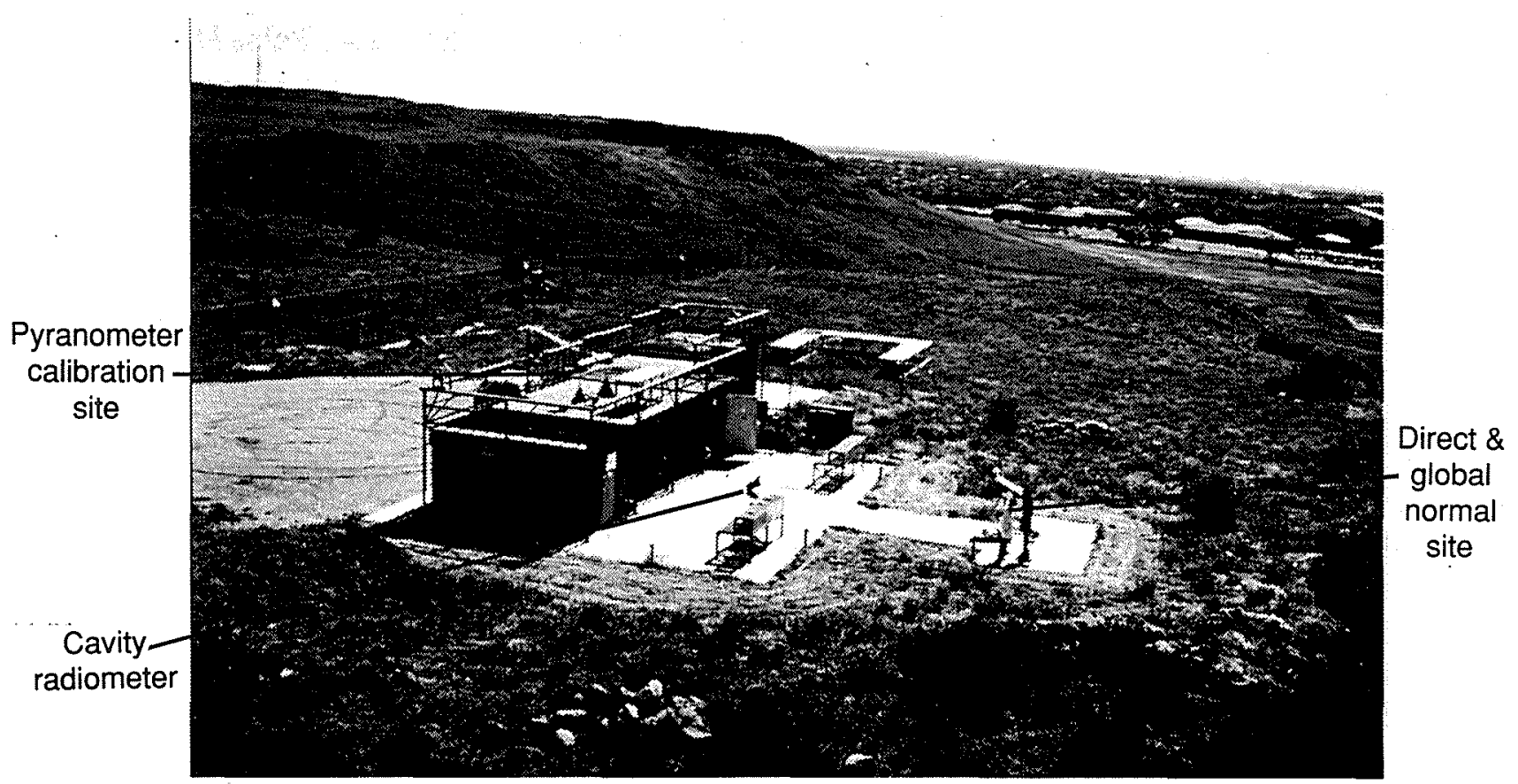

Figure 2-14. South Table Mountain Test Site Used for Global-Normal and Direct-Normal Calibrations 


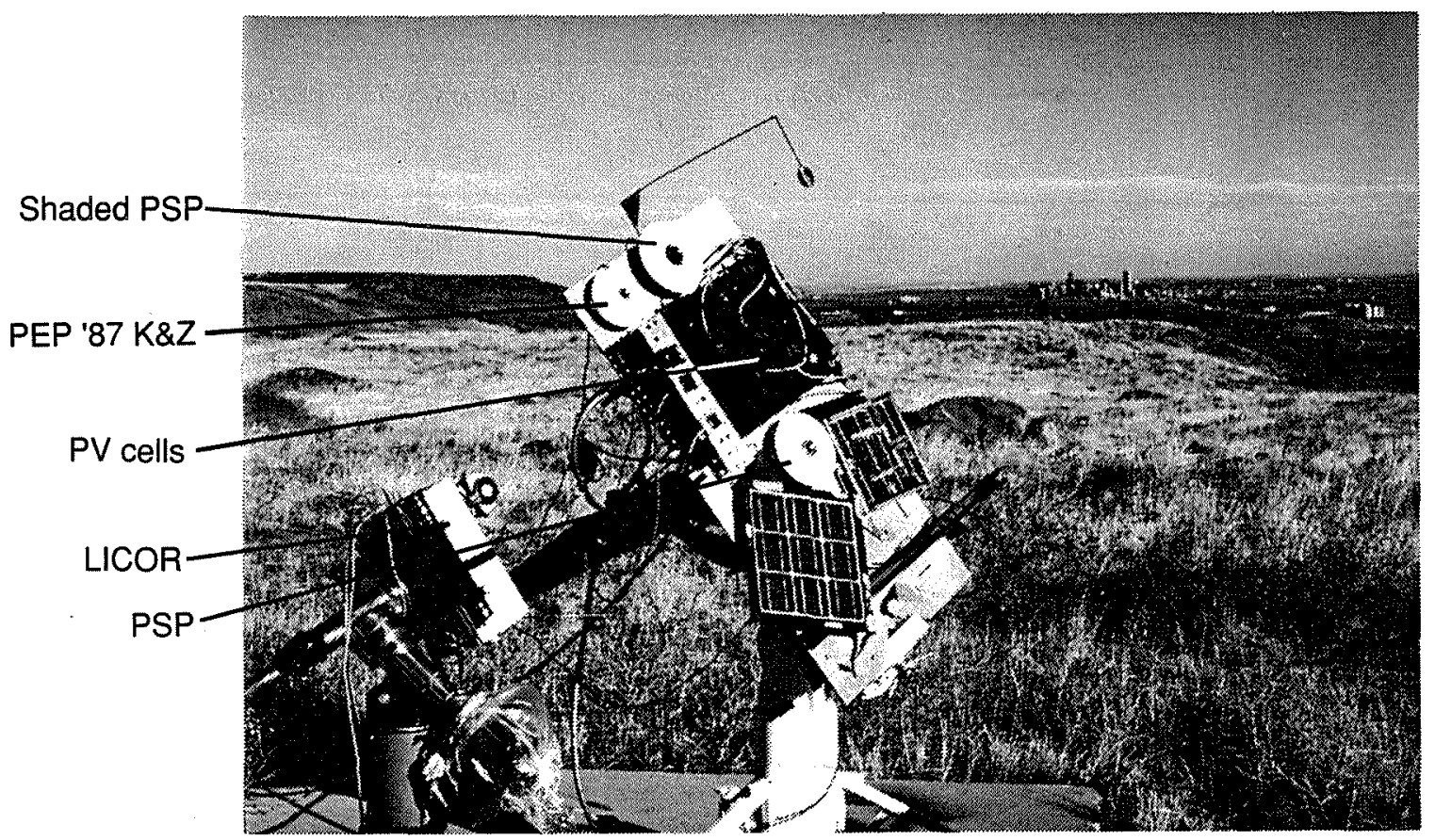

Figure 2-15. Sample Mounting Detail for Global-Normal Calibrations

Table 2-3. Global-Normal $U_{95}$ Calibration Uncertainty Using a Movable False Horizon

\begin{tabular}{lccc}
\hline \multicolumn{1}{c}{ Source } & $\begin{array}{c}\text { Bias } \\
(\%)\end{array}$ & $\begin{array}{c}\text { Random } \\
(\%)\end{array}$ & $\begin{array}{c}\text { Total }\left(U_{95}\right) \\
(\%)\end{array}$ \\
\hline$I_{s c}$ Kipp and Zonen CM11 pyranometer, or & 0.10 & 0.05 & 0.14 \\
$E_{\text {tot }}$ cavity radiometer + shaded pyranometer & 2.12 & 0.95 & 2.85 \\
$E_{\text {tot }}$ off normal-incidence alignment error & 0.59 & 0.24 & 0.71 \\
Spectral correction & 0.20 & - & 0.20 \\
Deviation from ideal cosine response & 0.20 & 0.50 & 1.02 \\
PV temperature correction & 0.02 & - & 0.02 \\
PV I linearity & 0.15 & 0.10 & 0.25 \\
Thermal voltages & 0.05 & 0.05 & 0.11 \\
Time constants & 0.05 & 0.05 & 0.11 \\
Field-of-view and ground reflections (false horizon) & 0.50 & 0.10 & 0.28 \\
\hline Total ( $E_{\text {tot }}$ from pyranometer) & 1.00 & 2.06 \\
Total ( $E_{\text {tot }}$ from cavity radiometer + pyranometer) & 0.82 & 1.16 & 2.46 \\
\hline
\end{tabular}




\subsubsection{Direct-Normal Method Used at SERI}

The calibration value $C V$ for a PV device with respect to a tabular reference spectrum is obtained using the following equation [14-16, 19-22] (see Appendix A):

$$
C V=\frac{I_{s c}^{R, S .} * k}{E_{t o t}}=\frac{I_{s c}^{R, S}}{E_{t o t}} * \frac{\int_{a}^{b} E_{r e f}(\lambda) * S_{r}(\lambda) d \lambda}{\int_{a}^{b} E_{r e f}(\lambda) d \lambda} * \frac{\int_{a}^{b} E_{s}(\lambda) d \lambda}{\int_{a}^{b} E_{s}(\lambda) * S_{r}(\lambda) d \lambda}
$$

where $E_{t o t}$ is the total power as measured by a broad-band detector. If $I_{s c}, E_{t o t}$, and $E_{s}(\lambda)$ are measured simultaneously with the same field-of-view, and if the relative spectral response of the cell to be calibrated, $S_{r}(\lambda)$, can be measured, then the calibration number for any given tabular reference spectrum can be obtained. Equation 2-10 is the same as Eq. 2-9 if the field-of-view is limited to $5^{\circ}$, and it is identical to the calibration equation for the proposed IEC global method in Appendix A. This method is also employed by ASTM standard E 1125 [20], and CEC Standard EUR 7078EN [21].

The elemental sources of error and the $U_{95}$ uncertainty limit are listed in Table 2-4. For bias errors, the dominant source is the bias of the cavity radiometer $[6,16,19,21]$. The major source of precision errors comes from the measurement of the solar spectral irradiance and the modeled extension of $E_{s}(\lambda)[12,14,18]$. If the measured wavelength range ( $a$ to $\left.b\right)$ of $E_{s}(\lambda)$ does not cover the wavelength range of the reference spectrum, $E_{\text {ref }}(\lambda)$, then the source and reference spectral irradiances must be assumed to integrate to the same value outside of the measured wavelength range. This is probably not a valid assumption. The effect of changing integration limits on the calibration value and standard deviation of the calibration value will be discussed in Section 3.5. The sample temperatures during calibration are controlled with a thermoelectric plate to within $\pm 2^{\circ} \mathrm{C}$. Two major advantages of the direct-normal calibration method are: a reduced uncertainty because the total irradiance is measured with a cavity radiometer, and that the fields-of-view for the cavity radiometer, reference cells, and the spectroradiometer can be accurately matched to within $\pm 0.01^{\circ}[12]$.

During the direct-normal calibrations at SERI, the range of total irradiance during any $30 \mathrm{sec}$ measurement period must be less than $0.1 \%$ and the range of short-circuit currents must be less than $0.2 \%$. This $30 \mathrm{sec}$ measurement period corresponds to the time required by the LI-1800 spectroradiometer to scan from 350 to $1100 \mathrm{~nm}$. Also, the short-circuit current and the total irradiance are sampled simultaneously using separate five-digit voltmeters. The direct-normal PV calibration tracker can calibrate four cells at the same time, as shown in Figure 2-16. Two separate equatorial telescope mounts are used, one for the spectroradiometer and the other for the four cells and their collimating tubes. 
Table 2-4. Direct-Normal $U_{95}$ Calibration Uncertainty

\begin{tabular}{lccc}
\hline \multicolumn{1}{c}{ Source } & $\begin{array}{c}\text { Bias } \\
(\%)\end{array}$ & $\begin{array}{c}\text { Random } \\
(\%)\end{array}$ & $\begin{array}{c}\text { Total }\left(U_{95}\right) \\
(\%)\end{array}$ \\
\hline$I_{s c}$ (primary absolute cavity radiometer) & 0.10 & 0.10 & 0.22 \\
$E_{t o t}$ & 0.37 & 0.13 & 0.45 \\
Spectral correction & 0.20 & 0.20 & 0.45 \\
Temperature control $\left( \pm 1^{\circ} \mathrm{C}\right)$ & 0.15 & 0.05 & 0.18 \\
PV $I_{s c}$ linearity & 0.05 & 0.05 & 0.11 \\
Thermal voltages & 0.05 & 0.05 & 0.11 \\
Time constants & 0.10 & - & 0.10 \\
\hline Total & 0.47 & 0.27 & 0.72 \\
\hline
\end{tabular}

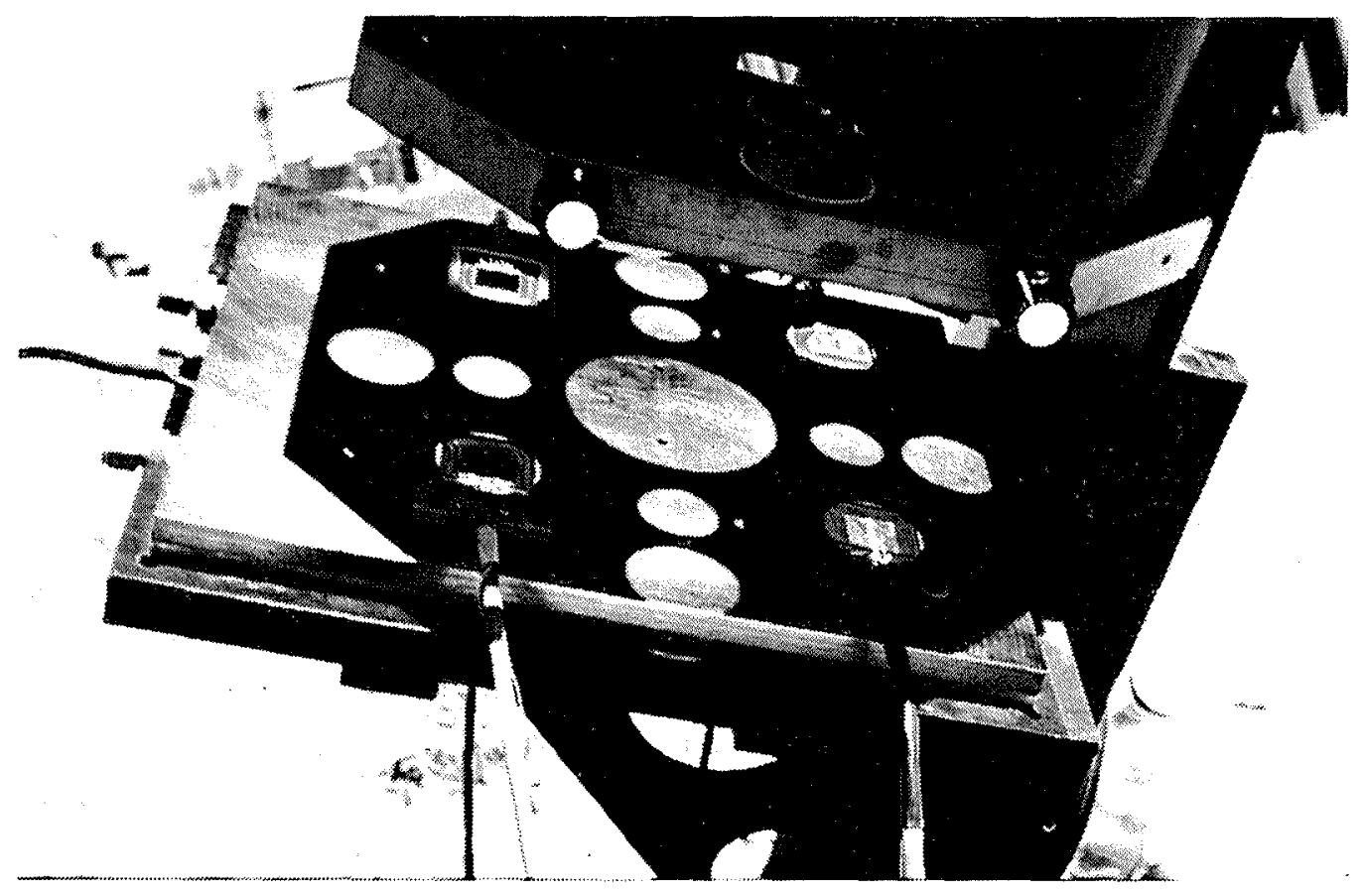

Figure 2-16. Sample Mounting Detail forDirect-Normal Calibrations

\subsubsection{Simulator-Based Secondary Calibration}

Secondary reference cell calibrations with a $U_{95}$ uncertainty limit of less than $\pm 2 \%$ can be achieved if careful attention is made to all sources of uncertainty and primary reference cells with an uncertainty limit of less than $\pm 1.0 \%$ are used. Primary AM0 and primary direct-normal reference have demonstrated an uncertainty limit of less than $\pm 1 \%[18,19,27-29]$. 
The simulator-based calibration method relies on Equation 2-7 to determine the short-circuit current with respect to the reference spectral and total irradiance. This method is similar to ASTM standard E 948 [30]. Published uncertainty analyses of the simulator-based calibration method have shown that bias errors are greater than random errors $[17,18]$. A major advantage of the Spectrolab $\mathrm{X}-25$ is its long focal length, about $2.4 \mathrm{~m}$, which results in a $\pm 1 \%$ spatial uniformity perpendicular to the test plane for a height of several centimeters. A major source of bias error is the reference cell calibration, which is $\pm 1.1 \%$ in Reference 17 and $\pm 0.5 \%$ in Reference 18 . The other major source of uncertainty in Eq. 2-6 is the spatial nonuniformity of the light source. Table 2-5 lists the estimated calibration uncertainty for the $X-25$ measurement system shown in Figure $2-17[15,19,29]$. The direct-normal reference cell calibration method (Table 2-2) was used to estimate the uncertainty, along with a $2 \mathrm{~cm}$ by $2 \mathrm{~cm}$ reference cell and a $10 \mathrm{~cm}$ by $10 \mathrm{~cm}$ secondary reference cell. The spectral mismatch corrections were calculated using the $\mathrm{X}-25$ spectral irradiance measured at the time of the SERI measurements (Figure 2-18).

Table 2-5. $U_{95}$ Uncertainty Limits for Spectrolab X-25 Solar Simulator Calibration (using a primary direct-normal reference cell and a custom data-acquisition system) [16]

\begin{tabular}{lccc}
\hline \multicolumn{1}{c}{ Source } & $\begin{array}{c}\text { Bias } \\
(\%)\end{array}$ & $\begin{array}{c}\text { Random } \\
(\%)\end{array}$ & $\begin{array}{c}\text { Total }\left(U_{95}\right) \\
(\%)\end{array}$ \\
\hline$I_{s c}$ Solar simulator spatial uniformity & 0.05 & 0.05 & 0.09 \\
Test cell temperature control $\left( \pm 1^{\circ} \mathrm{C}\right)$ & 0.50 & 0.05 & 0.50 \\
PV $I_{s c}$ linearity & 0.05 & 0.05 & 0.09 \\
Thermal emfs & 0.02 & 0.02 & 0.03 \\
Temporal variation in irradiance & 0.01 & 0.01 & 0.02 \\
Temporal variation in spatial uniformity & 0.05 & 0.05 & 0.09 \\
Spectral mismatch correction & 0.50 & 0.05 & 0.50 \\
Reference cell $I_{s c}$ & 0.20 & 0.18 & 0.41 \\
\hline Total & 0.72 & - & 0.72 \\
\hline
\end{tabular}

The estimated uncertainty of the Spire SPI-SUN Model 240 solar simulator (Figure 2-19) measurements is listed in Table $2-6$, and the spectral irradiance supplied by Spire is shown in Figure 2-20. Spectral mismatch errors were less than $\pm 0.5 \%$ for the test-device and reference-device combinations considered in this report. The uncertainty in the spectral mismatch corrections was greater than $\pm 0.5 \%$, and therefore spectral mismatch corrections were not applied and treated as bias. Because multiple readings of the reference cell short-circuit current were not taken, the uncertainty in reference cell $I_{s c}$ was also treated as bias. As for the Spectrolab X-25 measurement system case, a $2 \mathrm{~cm}$ by $2 \mathrm{~cm}$ reference cell and a $10 \mathrm{~cm}$ by $10 \mathrm{~cm}$ test cell were assumed. The spatial uniformity of the SPI-SUN Model 240 is specified as $\pm 3 \%$ over the 1.22 by $0.61 \mathrm{~m}$ test plane. 


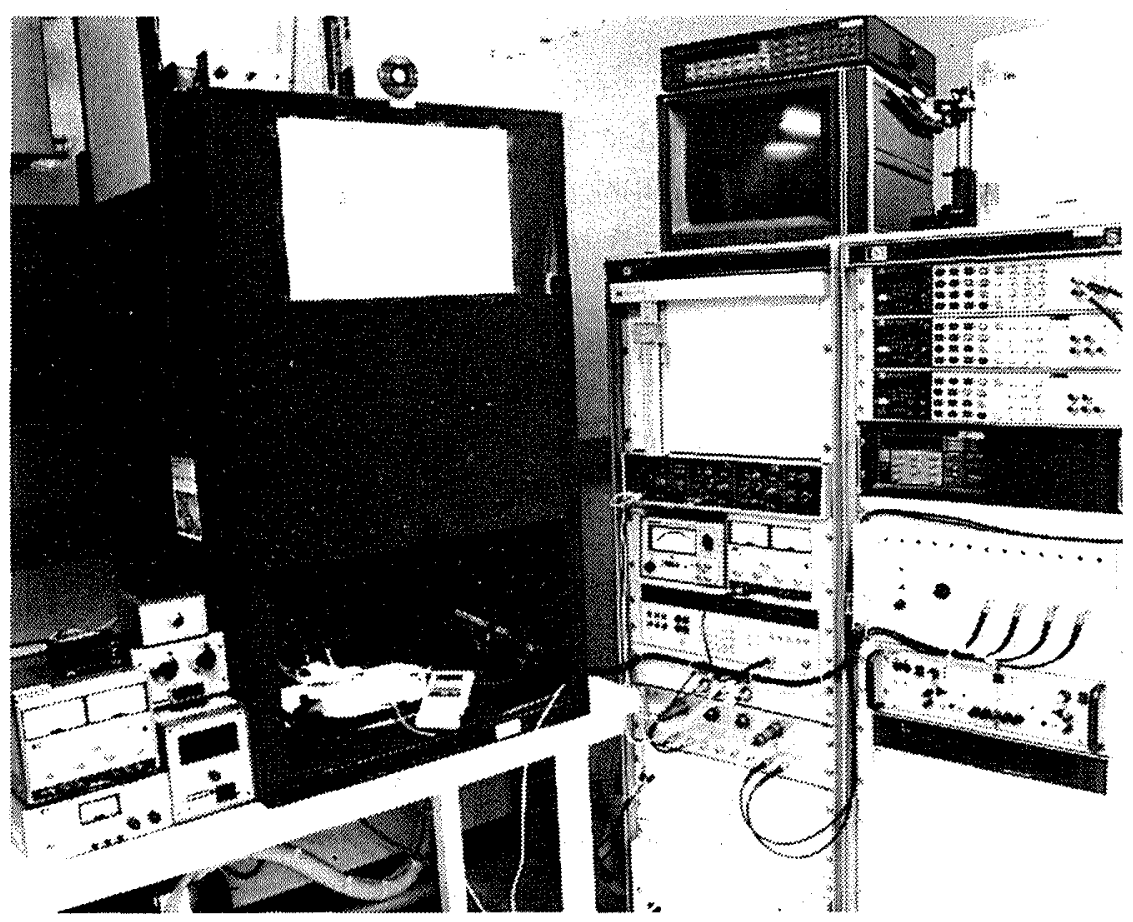

Figure 2-17. Spectrolab X-25 Solar Simulator with Custom Data-Aquisition System

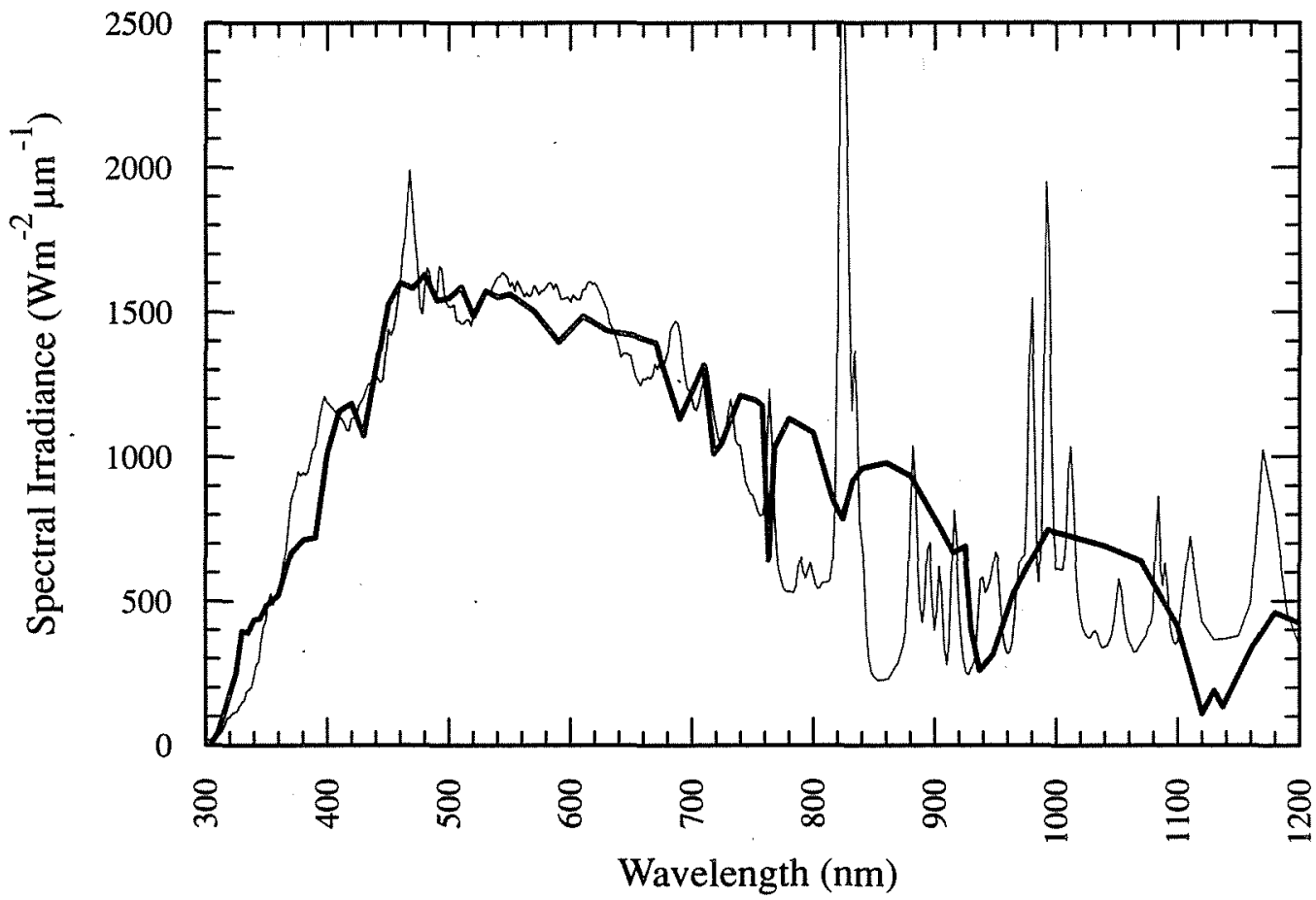

Figure 2-18. Spectal Irradiance of Spectrolab X-25 Simulator and the Global Reference Spectrum (bold line) 


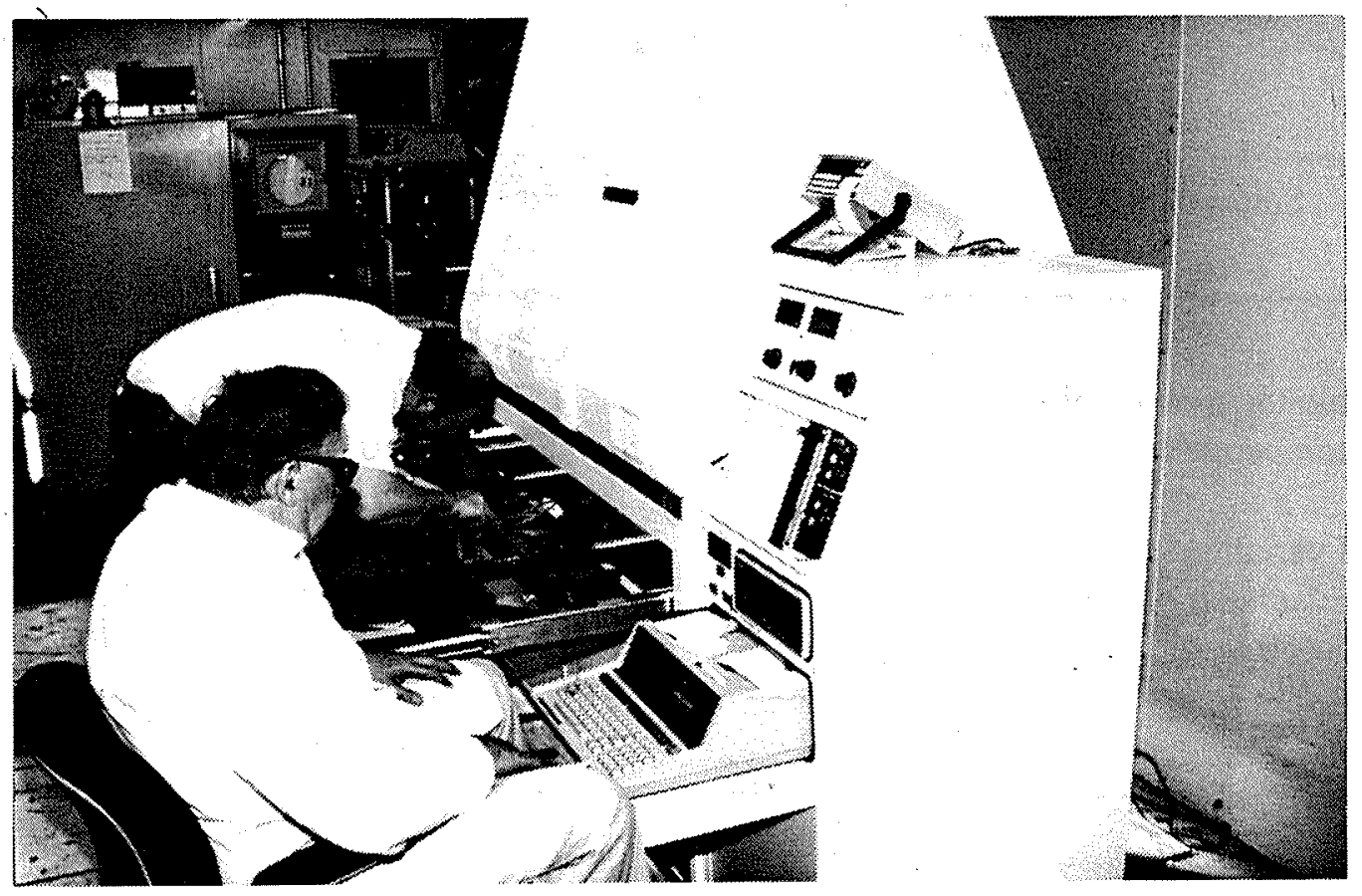

Figure 2-19. Spire SPI-SUN Model 240 PV Measurement System

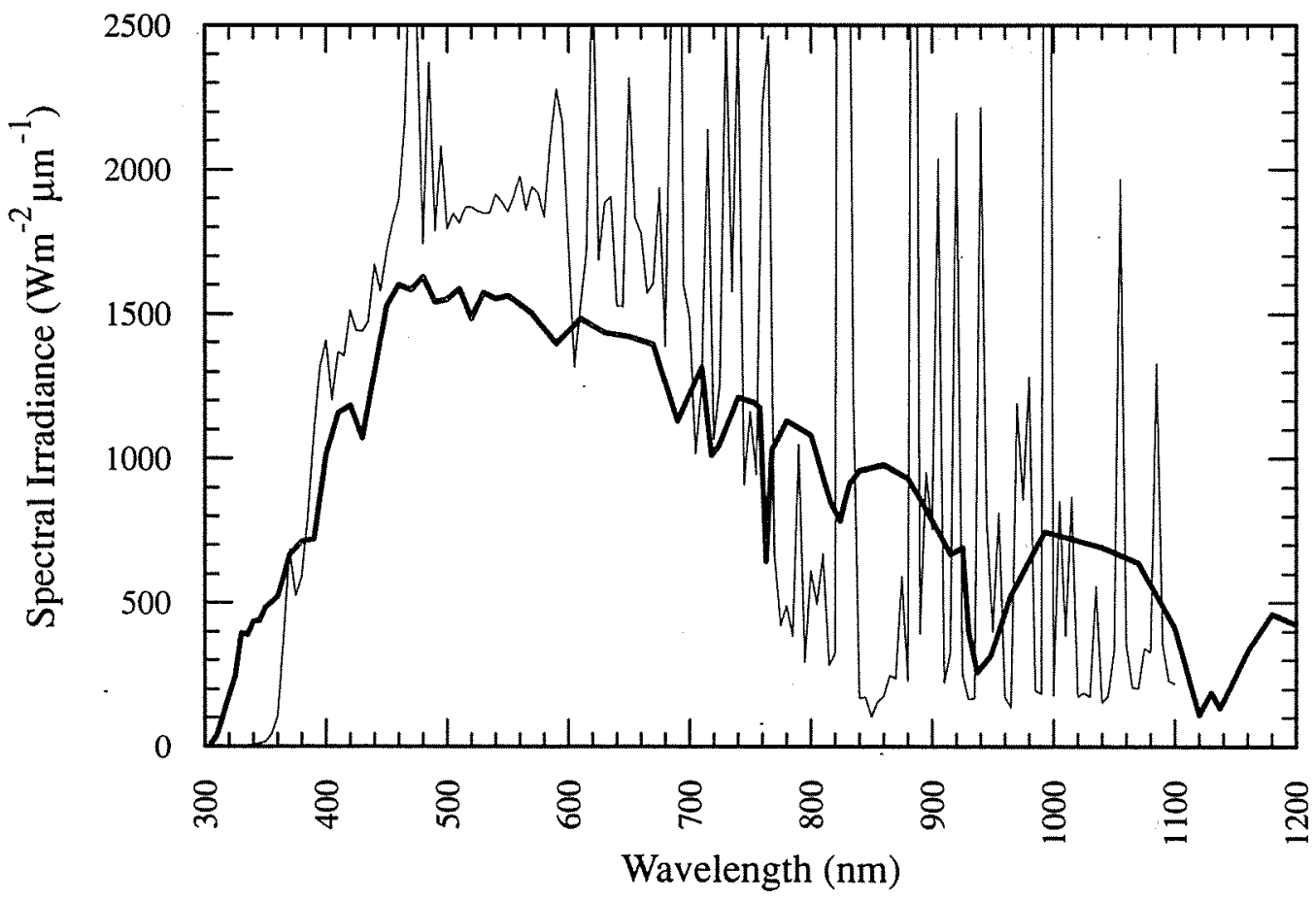

Figure 2-20. SPI-SUN Model 240 Spectral Irradiance Supplied by Spire and the Global Reference Spectrum (bold line) 
Table 2-6. $U_{95}$ Uncertainty Limits for Spire SPI-SUN 240 Solar Simulator Calibration (using a primary direct-normal reference cell)

\begin{tabular}{lccc}
\hline \multicolumn{1}{c}{ Source } & $\begin{array}{c}\text { Bias } \\
(\%)\end{array}$ & $\begin{array}{c}\text { Random } \\
(\%)\end{array}$ & $\begin{array}{c}\text { Total }\left(U_{9 s}\right) \\
(\%)\end{array}$ \\
\hline$I_{s c}$ & 0.50 & 0.50 & 1.12 \\
Solar simulator spatial uniformity & 1.00 & 1.00 & 2.24 \\
Test cell temperature control $\left( \pm 1^{\circ} \mathrm{C}\right)$ & 0.05 & 0.05 & 0.09 \\
PV $I_{s c}$ linearity & 0.10 & 0.10 & 0.22 \\
Temporal variation & 0.50 & 0.50 & 1.12 \\
Spectral mismatch correction & 0.50 & - & 0.50 \\
Reference cell $I_{s c}$ & 1.00 & - & 1.00 \\
\hline Total & 1.66 & 1.23 & 2.97 \\
\hline
\end{tabular}

\subsubsection{Summary of PV Calibration Uncertainties}

The calibration uncertainty for the primary global-normal, primary global fixed-tilt, primary direct-normal, secondary simulator-based methods, and primary AM0 calibration methods compared in this report are summarized in Table 2-7.

Table 2-7. Summary of PV Calibration Uncertainties

\begin{tabular}{llccc}
\hline Calibration Method & $E_{\text {tot }}$ & $\begin{array}{c}\text { Bias } \\
(\%)\end{array}$ & $\begin{array}{c}\text { Random } \\
(\%)\end{array}$ & $\begin{array}{c}\text { Total }\left(U_{95}\right) \\
(\%)\end{array}$ \\
\hline Global fixed-tilt & pyranometer & 3.06 & 1.48 & 4.26 \\
Global fixed-tilt & direct + diffuse & 2.29 & 1.16 & 3.24 \\
Global-normal & pyranometer & 2.49 & 1.48 & 3.69 \\
Global-normal & direct + diffuse & 0.82 & 1.16 & 2.46 \\
Direct-normal & cavity radiometer & 0.47 & 0.27 & 0.72 \\
X-25 simulator & direct-normal reference cell & 1.03 & 0.21 & 1.09 \\
SPI-SUN Simulator & direct-normal reference cell & 1.44 & 1.23 & 2.97 \\
AM0 (NASA airplane calibration) [28] $\dagger$ & 1.00 & - & 1.00 \\
AM0 (JPL ballon calibration) [27] $\dagger$ & 0.50 & 0.24 & 0.69 \\
\hline
\end{tabular}

$\dagger$ A standard uncertainty analysis has not been performed for AM0 calibration methods; these are estimates based on published information. 
TR-213-3472

\subsection{SERI PV CALIBRATION RESULTS FOR THE PEP'87 INTERCOMPARISON}

\subsection{Experimental Approach}

The experimental approach used for the PEP '87 intercomparison divided the PV calibration task into three phases. The first phase involved an initial inspection of the PV samples for loose or broken thermocouples and for any physical damage. The $I-V$ characteristics were measured at three temperatures against a primary reference cell that was calibrated using the direct-normal method. From these data the $I_{s c}$ temperature coefficients were calculated, and the spectral responses of the single- and multiple-cell reference devices were then measured. The pyranometers used in this study were also calibrated prior to the outdoor PV measurements.

The second phase involved the actual outdoor PV calibrations under global-normal and global fixed-tilt irradiance. The direct-normal, diffuse, and total irradiance in the plane-of-measurement were obtained at the same time as the PV short-circuit current, along with the spectral irradiance. The meteorological parameters, measured at the same time as the total irradiance, spectral irradiance and PV $I_{s c}$, include the wind speed, wind direction, barometric pressure, and air temperature. Data were collected for a minimum of five times on three separate days. Appendix $\mathrm{C}$ lists the uncorrected global fixed-tilt calibration data for the reference devices in multiple-cell packages and modules.

The third phase involved reducing the data. Each data point was corrected to $25^{\circ} \mathrm{C}$ and the global reference spectrum listed in Table A-2, using wavelength integration limits of 340 to $1100 \mathrm{~nm}$. The corrected calibration value $C V$ for all of the data points were averaged to give a single calibration value $\langle C V\rangle$ for each sample. After a calibration value was assigned to the each sample, the $I-V$ parameters were remeasured with the simulator set using the matching reference cell in a single-cell or multiple-cell package. These data aresummarized in this section and in Appendix B.

\subsection{Reference Cells in Single-Cell Packages}

\subsubsection{Data Summary}

The calibration values for the PEP ' 87 reference devices using the global-normal and simulator methods are summarized in Tables $3-1$ and B-2. These calculations were carried out to four significant digits to minimize round-off error. The $\pm 1 \%$ agreement between the two global methods and the simulator method for the calibration values is well within their mutual uncertainties, which is as much as $\pm 3.7 \%$ (see Table $2-7$ ). The difference in the uncertainty limits between the two global-normal methods is mostly bias and is due to the pyranometer having much larger bias limits than the cavity radiometer, as seen in Table $2-1$. 
Table 3-1. Summary of $I_{s c}$ Calibrations (amperes) for Reference Cells in Single-Cell Packages.

Corrected to $25^{\circ} \mathrm{C}, 1000 \mathrm{Wm}^{-2}$, and the global reference spectrum.

\begin{tabular}{cccc}
\hline Sample & \multicolumn{2}{c}{ Global-Normal } & \multicolumn{2}{c}{ Spectrolab X-25 Simulator Using a } \\
& $\begin{array}{c}\text { Pyranometer } \\
U_{95}=3.7 \%\end{array}$ & $\begin{array}{c}\text { Direct + Diffuse } \\
U_{95}=2.5 \%\end{array}$ & $\begin{array}{c}\text { Primary Direct-Normal Reference Cell } \\
U_{95}=1.0 \%\end{array}$ \\
\hline RC-01 & 0.02527 & 0.02551 & 0.02604 \\
RC-02 & 0.02494 & 0.02518 & 0.02549 \\
RC-03 & 0.11112 & 0.11212 & 0.11156 \\
RC-04 & 0.11196 & 0.11298 & 0.11147 \\
RC-05 & 0.09706 & 0.09788 & 0.09743 \\
RC-06 & 0.09650 & 0.09755 & 0.09778 \\
RC-07 & 0.11648 & 0.11754 & 0.11724 \\
RC-08 & 0.03315 & 0.03344 & 0.03420 \\
\hline
\end{tabular}

The short-circuit currents of all the reference cells in single-cell packages were sequentially measured using the Spectrolab X-25 a minimum of five times, at the $25^{\circ} \mathrm{C}$ reference temperature according to the thermocouple, and with no adjustments to the simulator. The samples were kinematically mounted to minimize spatial nonuniformity errors, and the three primary direct-normal reference cells used for the simulator calibration method were also measured at this time. The $\pm 1 \%$ fluctuations in the total irradiance, which caused a $\pm 1 \%$ fluctuation in the measured $I_{s c}$, were reduced using a separate temperature-controlled intensity monitor located in the test plane. All cells were actively biased to within $\pm 0.5 \mathrm{mV}$ of $I_{s c}$ using a feedback network. This was especially important because of the $-1.5 \mathrm{mAV}^{-1}$ slope-at $-I_{s c}$ for the amorphous silicon cells $\mathrm{RC}-01$ and $\mathrm{RC}-02$ that could result in a nearly $1 \%$ bias error in the calibration for measurements $10 \mathrm{mV}$ from $I_{s c}$.

The rather large thermal mass of the single-cell packages complicated temperature coefficient measurements because more than $15 \mathrm{~min}$ was required to reach thermal equilibrium after a change in temperature or heat load (this reference cell package design utilizes most of the thermal mass for an integral water cooling assembly). The Spectrolab X-25 measurement system uses thermoelectric temperature control, which has a relatively fast response time to a change in temperature or heat load (<1 min). Table 3-2 summarizes the short-circuit current temperature coefficients, in ppm per ${ }^{\circ} \mathrm{C}$ normalized to $25^{\circ} \mathrm{C}$, for all of the samples in the PEP ' 87 intercomparison, as measured using the attached thermocouple. For samples which had no thermocouple, the back surface temperature was measured. Three short-circuit currents were measured 15,25 , and $35^{\circ} \mathrm{C}$ for the reference cells in single-cell packages giving an estimated temperature coefficient uncertainty of $\pm 10 \%$, and for the modules and reference cells in multiple-cell packages, three short-circuit currents were measured at 20,25 , and $35^{\circ} \mathrm{C}$, resulting in an estimated temperature-coefficient uncertainty of $\pm 20 \%$. Because of the $1 \mathrm{~mA}$ minimum resolution of the SPI-SUN 240 system, the uncertainty for the amorphous 
silicon modules and reference cells in multiple-cell packages was estimated to be $\pm 30 \%$. The temperature-corrected $I_{s c}$ was then calculated [15] using

$$
I_{s c}\left(25^{\circ} \mathrm{C}\right)=I_{s c}\left(T_{m}\right)+\frac{10^{-6} * A * I_{s c}\left(T_{m}\right) *\left(25^{\circ} \mathrm{C}-T_{m}\right)}{1-A * 10^{-6} *\left(25^{\circ} \mathrm{C}-T_{m}\right)}
$$

where $I_{s c}\left(T_{m}\right)$ is the short-circuit current at any measured temperature $T_{m}$ and $A$ is the temperature coefficient calculated using

$$
T_{c o e f}=\left.\frac{10^{6}}{I_{s c}} * \frac{\delta I_{s c}}{\delta T_{m}}\right|_{T_{m}=25^{\circ} \mathrm{C}}
$$

After the corrected short-circuit current $I_{s c}^{T, C}$ (Eq. 2-6) was calculated, the spectral response was measured using a white-light bias equal to this current. As described in Section 3.2.3, the absolute spectral response and spectrally-corrected short-circuit current $I_{s c}^{T, R}$ (Eq. 2-7) was then calculated. Table 3-3 summarizes the absolute spectral response results for the PEP ' 87 reference devices in single-cell packages. It should be noted that the spectral response values are proportional to the device areas used for the response calculations (the areas of the single-cell package devices were not measured).

Table 3-2. $I_{s c}$ Temperature Coefficients $\left(\mathrm{ppm}^{\circ} \mathrm{C}^{-1}\right)$ Normalized to $25^{\circ} \mathrm{C}$

\begin{tabular}{cccc}
\hline $\begin{array}{l}\text { Sample Number } \\
(\text { RC, RM, or SM) }\end{array}$ & $\begin{array}{l}\text { Cell in Single- } \\
\text { Cell Package }\end{array}$ & $\begin{array}{l}\text { Cell in Multiple- } \\
\text { Cell Package }\end{array}$ & Modules \\
-01 & 949 & 1575 & 1589 \\
-02 & 1086 & 1327 & 1936 \\
-03 & 569 & 550 & 588 \\
-04 & 584 & 683 & 375 \\
-05 & 1344 & 1759 & 1927 \\
-06 & 1542 & 3078 & - \\
-07 & 556 & - & \\
-08 & -276 & - & \\
S01 & 482 & & \\
S10 & -321 & & \\
DSET-026 & 463 & & \\
\hline
\end{tabular}


Table 3-3. Absolute Spectral Response for $4 \mathrm{~cm}^{2}$ Reference Cells in Single-Cell Packages $\left(\mathrm{AW}^{-1}\right)$

\begin{tabular}{|c|c|c|c|c|c|c|c|c|}
\hline$\lambda(\mathrm{nm})$ & $\begin{array}{c}\mathrm{RC}-01 \\
S_{r}(\lambda)\end{array}$ & $\begin{array}{c}\mathrm{RC}-02 \\
S_{r}(\lambda)\end{array}$ & $\begin{array}{c}\mathrm{RC}-03 \\
S_{r}(\lambda)\end{array}$ & $\begin{array}{c}\mathrm{RC}-04 \\
S_{r}(\lambda)\end{array}$ & $\begin{array}{c}\mathrm{RC}-05 \\
S_{r}(\lambda)\end{array}$ & $\begin{array}{c}\mathrm{RC}-06 \\
S_{r}(\lambda)\end{array}$ & $\begin{array}{c}\mathrm{RC}-07 \\
S_{r}(\lambda)\end{array}$ & $\begin{array}{c}\mathrm{RC}-08 \\
S_{r}(\lambda)\end{array}$ \\
\hline 360 & 0.6014 & 0.0558 & 0.0688 & 0.0836 & 0.0169 & 0.0176 & 0.0211 & 0.0000 \\
\hline 380 & 0.0774 & 0.0687 & 0.0576 & 0.0881 & 0.0226 & 0.0234 & 0.0211 & 0.0203 \\
\hline 400 & 0.0877 & 0.0811 & 0.1256 & 0.1313 & 0.0856 & 0.1007 & 0.1045 & 0.0988 \\
\hline 420 & 0.1013 & 0.0986 & 0.1756 & 0.1721 & 0.1336 & 0.1545 & 0.1642 & 0.1586 \\
\hline 440 & 0.1193 & 0.1164 & 0.2057 & 0.2013 & 0.1640 & 0.1870 & 0.2003 & 0.2016 \\
\hline 460 & 0.1328 & 0.1269 & 0.2328 & 0.2287 & 0.1911 & 0.2156 & 0.2329 & 0.2396 \\
\hline 480 & 0.1353 & 0.1312 & 0.2552 & 0.2509 & 0.2138 & 0.2384 & 0.2605 & 0.2726 \\
\hline 500 & 0.1408 & 0.1411 & 0.2789 & 0.2735 & 0.2380 & 0.2653 & 0.2926 & 0.3044 \\
\hline 520 & 0.1512 & 0.1535 & 0.2961 & 0.2930 & 0.2553 & 0.2823 & 0.3143 & 0.3211 \\
\hline 540 & 0.1658 & 0.1660 & 0.3149 & 0.3130 & 0.2743 & 0.3029 & 0.3396 & 0.3287 \\
\hline 560 & 0.1719 & 0.1672 & 0.3348 & 0.3297 & 0.2903 & 0.3195 & 0.3609 & 0.3083 \\
\hline 580 & 0.1676 & 0.1608 & 0.3507 & 0.3450 & 0.3047 & 0.3348 & 0.3807 & 0.2610 \\
\hline 600 & 0.1533 & 0.1518 & 0.3633 & 0.3590 & 0.3171 & 0.3473 & 0.3968 & 0.1881 \\
\hline 620 & 0.1470 & 0.1339 & 0.3723 & 0.3724 & 0.3256 & 0.3606 & 0.4105 & 0.1147 \\
\hline 640 & 0.1395 & 0.1379 & 0.3942 & 0.3892 & 0.3420 & 0.3743 & 0.4318 & 0.0598 \\
\hline 660 & 0.1130 & 0.1324 & 0.4019 & 0.4020 & 0.3488 & 0.3828 & 0.4435 & 0.0269 \\
\hline 680 & 0.1062 & 0.1076 & 0.4114 & 0.4094 & 0.3565 & 0.3882 & 0.4522 & 0.0109 \\
\hline 700 & 0.0971 & 0.0792 & 0.4259 & 0.4240 & 0.3666 & 0.3991 & 0.4677 & 0.0033 \\
\hline 725 & 0.0510 & 0.0476 & 0.4466 & 0.4455 & 0.3809 & 0.4152 & 0.4906 & 0.0006 \\
\hline 750 & 0.0510 & 0.0234 & 0.4676 & 0.4644 & 0.3908 & 0.4270 & 0.5092 & 0.0001 \\
\hline 775 & 0.0070 & 0.0096 & 0.4804 & 0.4766 & 0.3953 & 0.4322 & 0.5209 & - \\
\hline 800 & 0.0025 & 0.0028 & 0.4783 & 0.4790 & 0.3907 & 0.4256 & 0.5197 & - \\
\hline 825 & 0.0013 & 0.0010 & 0.4955 & 0.4994 & 0.4002 & 0.4351 & 0.5389 & - \\
\hline 850 & 0.0007 & 0.0004 & 0.4962 & 0.4999 & 0.3897 & 0.4244 & 0.5362 & - \\
\hline 877 & 0.0004 & 0.0002 & 0.5073 & 0.5094 & 0.3861 & 0.4212 & 0.5440 & - \\
\hline 900 & - & - & 0.5013 & 0.5001 & $0: 3687$ & 0.4022 & 0.5330 & - \\
\hline 927 & - & - & 0.4886 & 0.5030 & 0.3474 & 0.3772 & 0.5140 & - \\
\hline 950 & - & - & 0.4829 & 0.4850 & 0.3264 & 0.3548 & 0.4977 & - \\
\hline 977 & - & - & 0.4414 & 0.3913 & 0.2865 & 0.3109 & 0.4509 & - \\
\hline 1000 & - & - & 0.3843 & 0.3206 & 0.2367 & 0.2558 & 0.3857 & - \\
\hline 1026 & - & - & 0.3108 & 0.2575 & 0.1842 & 0.1982 & 0.3143 & - \\
\hline 1050 & - & - & 0.2492 & 0.3040 & 0.1336 & 0.1450 & 0.2212 & - \\
\hline 1075 & - & - & 0.2065 & 0.2229 & 0.1028 & 0.1131 & 0.1525 & - \\
\hline 1100 & - & - & 0.1719 & 0.1829 & 0.0764 & 0.0858 & 0.0999 & - \\
\hline 1150 & - & - & 0.1108 & 0.0779 & 0.0402 & 0.0428 & 0.0470 & - \\
\hline 1200 & - & - & 0.0031 & 0.0028 & 0.0009 & 0.0008 & 0.0009 & - \\
\hline \multicolumn{9}{|c|}{ Light bias (mA): } \\
\hline & 26.1 & 25.49 & 117.4 & 111.54 & 88.99 & 97.75 & 116.63 & 34.29 \\
\hline
\end{tabular}




\subsubsection{Discussion}

The precision error in the calibration value can be estimated from the standard deviation $(\sigma)$ of the calibration value divided by the mean calibration value for all of the samples and data points. The $2 \sigma$ value was $\pm 1.6 \%$ for $E_{\text {tot }}$ measured with the Kipp \& Zonen CM11-4 and $\pm 1.8 \%$ for $E_{\text {tot }}$ measured from the direct-plus-diffuse. Figures 3-1 and 3-2 show the variation in the calibration value for each data point divided by the mean calibration value, or $C V /\langle C V\rangle$, as a function of solar elevation angle. The "+" symbols denote data collected before solar noon and the "०" symbols denote data collected after solar noon. This method of presenting the normalized calibration value allows all of the data samples to be compared and can identify cosine, field-of-view, and time-of-day errors. The range of solar elevation angles corresponded to a relative optical air mass from 1.99 to 3.34, while the absolute (pressure-corrected) optical air mass ranged from 1.59 to 2.62 . The solar elevation was calculated using the modified method of Walraven [31, 32] and the refraction-corrected relative optical air mass from Iqbal [33]. There is no. apparent difference between morning and afternoon calibration data, indicating that the changing irradiance from the ground with the time of day does not appreciably affect the data. This is not surprising considering that the ratio of the diffuse-to-direct component for the extremely clear sky conditions varied from 0.062 to 0.070 and was as high as 0.092 for the partly cloudy conditions encountered on one of the days. Figure 3-3 illustrates the variation in uniformity as a function of solar elevation using the ratio of $E_{\text {tor }}$ measured by two different pyranometers mounted on the same plane as the reference cells. One Kipp \& Zonen CM11-4 was situated to the north and the other was below the reference devices in single-cell packages but above the reference devices in multiple-cell packages. Because the pyranometer locations were not. switched, calibration bias may explain why the ratio is not unity, even though no variation with time of day is evident in Figure 3.3.

\subsection{Reference Devices in Multiple-Cell Packages}

\subsubsection{Data Summary}

The calibration values for the reference devices in multiple-cell packages using the global fixed-tilt method is summarized in Table B-2 (Appendix B), and Table 3-4 gives the short-circuit currents determined using the solar simulator, global fixed-tilt, and global-normal methods.

The data in Table 3-4 are well within the mutual estimated $U_{95}$ uncertainties listed in Table 2-6 for the five calibration methods. The global fixed-tilt data are $4 \pm 1 \%$ lower than both the simulator method and the global-normal method, which may indicate a bias in the global fixed-tilt measurement. The Spire SPI-SUN solar simulator is $0.5 \pm 0.8 \%$ higher compared to the Spectrolab X-25 measurement system, a result which is well within the estimated uncertainties. 


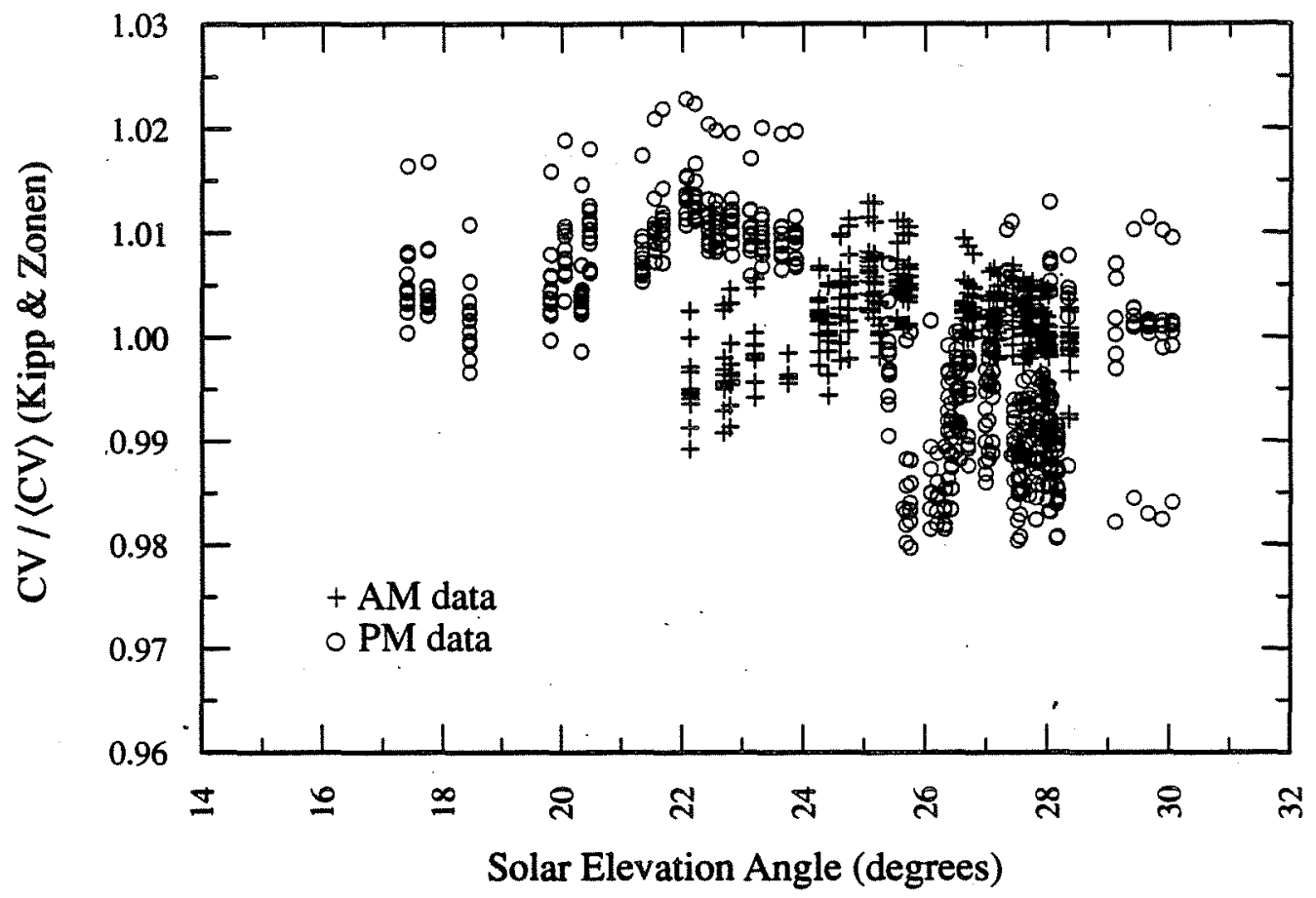

Figure 3-1. $C V /\langle C V\rangle$ vs. Solar Elevation for $E_{\text {tot }}$ Measured with Kipp \& Zonen CM11 830092

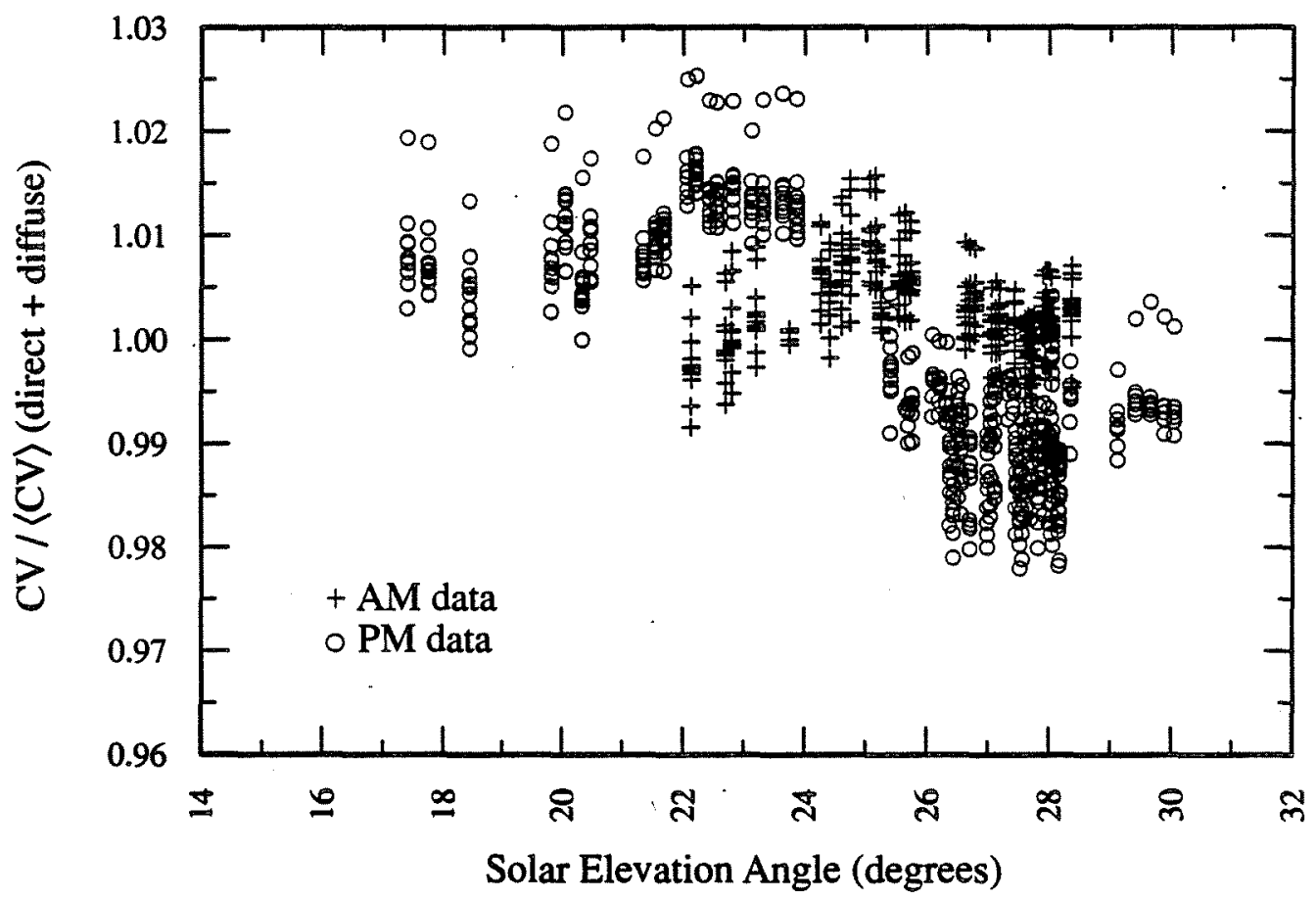

Figure 3-2. $C V /\langle C V\rangle$ vs. Solar Elevation for $E_{\text {tot }}$ Measured with Direct-Plus-Diffuse Irradiance 


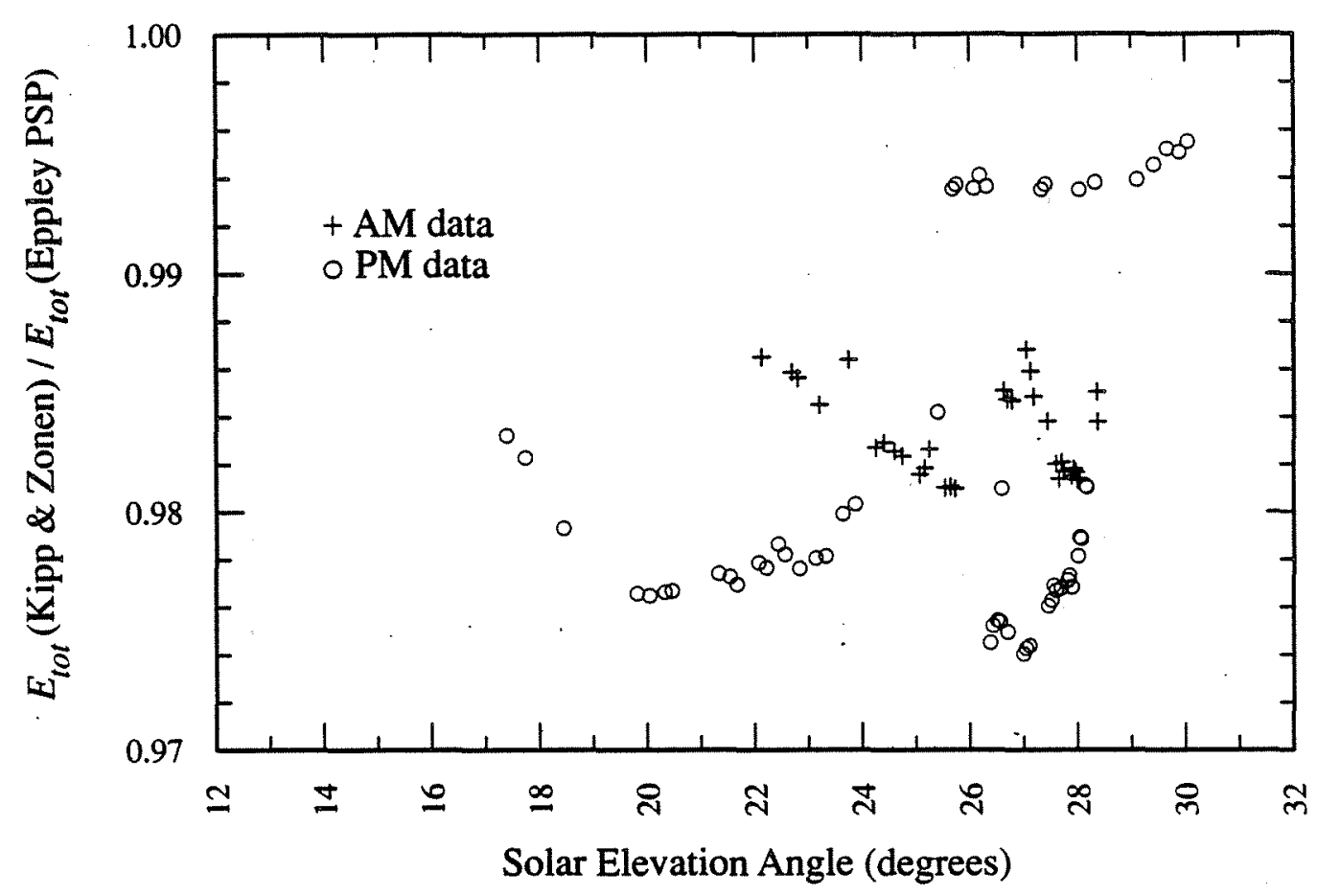

Figure 3-3. Ratio of the Plane-of-Measurement Total Irradiance Above the PV Samples to the Total Irradiance at the Center of the Plane-of-Measurement (See Figure 2-15)

Table 3-4. Summary of $I_{s c}$ Calibrations (amperes) for Reference Devices in Multiple-Cell Packages.

Corrected to $25^{\circ} \mathrm{C}, 1000 \mathrm{Wm}^{-2}$, and the global reference spectrum.

\begin{tabular}{|c|c|c|c|c|c|c|}
\hline \multirow[t]{2}{*}{ Sample } & \multicolumn{2}{|c|}{ Global Fixed-Tilt } & \multicolumn{2}{|c|}{ Global Normal } & \multicolumn{2}{|c|}{ Simulator } \\
\hline & $\begin{array}{c}\text { Pyranometer } \\
U_{95}=4.3 \%\end{array}$ & $\begin{array}{c}\text { Direct + Diffuse } \\
U_{95}=3.3 \%\end{array}$ & $\begin{array}{c}\text { Pyranometer } \\
U_{95}=3.7 \%\end{array}$ & $\begin{array}{c}\text { Direct + Diffuse } \\
U_{9 S}=2.5 \%\end{array}$ & $\begin{array}{l}\text { SPI-SUN } \\
U_{95}=3.0 \%\end{array}$ & $\begin{array}{c}\mathrm{X}-25 \\
U_{95}=1.0 \%\end{array}$ \\
\hline $\mathrm{RM}-01$ & 0.09127 & 0.09342 & - & - & 0.097 & 0.0954 \\
\hline $\mathrm{RM}-02$ & 0.09797 & 0.1007 & - & - & 0.105 & 0.1043 \\
\hline $\mathrm{RM}-03$ & 2.809 & 2.877 & 2.877 & 2.904 & 2.953 & 2.935 \\
\hline RM-04 & 2.830 & 2.895 & - & - & 2.973 & 2.946 \\
\hline $\mathrm{RM}-05$ & 2.465 & 2.486 & 2.505 & 2.529 & 2.527 & 2.539 \\
\hline $\mathrm{RM}-06$ & 2.470 & 2.488 & - & - & 2.523 & 2.534 \\
\hline
\end{tabular}


The $I-V$ data for the RM-series samples (reference devices in multiple-cell packages) are given in Table 3-5. The Spectrolab X-25 measurements were used in the PEP ' 87 data sheets in Tables B-2 to $\mathrm{B}-6$ for the RM- and RC-series samples. In addition to the global fixed-tilt short-circuit current, the $I-V$ characteristics for the reference devices in multiple-cell packages were measured at the same time and are given in Tables $\mathrm{C}-1$ to $\mathrm{C}-6$. The data in Table 3-5, obtained with the SERI single-crystal silicon primary reference cell $\mathrm{SO} 1$ and the filtered-silicon reference cell $\mathrm{S} 10$, were corrected for any spectral mismatch greater than $1 \%$. Also, the uncorrected calibration value $C V_{U}$ was corrected to $25^{\circ} \mathrm{C}$ using the temperature coefficients given in Table 3-3 for the cells (RC-series) because of the reduced uncertainty.

The corresponding RC-series (reference cell in a single-cell package) spectral response (Table 3-2) was used to determine the spectral correction factor $k$. A summary of the measured spectral response for the RM-series devices is given in Table 3-6. Because of the $3 \mathrm{~cm}$ diameter of the monochromatic beam. the series-connected. multiple-cell packaged amorphous silicon devices could not be measured. All of the spectral response data were normalized to integrate to the short-circuit currents given in Table B-2 using a nominal sample area of $100 \mathrm{~cm}^{2}$.

\subsubsection{Discussion}

The open-circuit voltages in Table 3-5 are significantly higher, about $30 \mathrm{mV}$ average, for the Spectrolab X-25 measurements than for those made with the Spire SPI-SUN Model 240 system. This is within the resolution of the SPI-SUN 240 16-bit D-A converters. As in the case of the reference cells in single-cell packages (Section 3.2.2), the precision error in the calibration value can be estimated from the standard deviation of $C V$ divided by $\langle C V\rangle$ for all of the samples. The $2 \sigma$ value was $\pm 1.6 \%$ for $E_{t \prime \prime}$ measured with the PEP ' $87 \mathrm{Kipp}$ \& Zonen CM11-4 and $\pm 3.0 \%$ for $E_{t \prime \prime \prime}$ determined from the direct-plus-diffuse method.

Figures 3-4 and 3-5 show the variation in the normalized calibration value, $C V /\langle C V\rangle$, as a function of the plane-of-measurement to sun-angle for all of the RM- and SM-series fixed-tilt calibrations. Again. the "+" symbol denotes data collected before solar noon and the "o" symbol denotes data collected after solar noon. There appears to be a definite AM-to-PM and time-of-day dependence in Figure 3-5 but not in Figure 3-4. Figure 3-6 graphically illustrates this as the ratio of the total irradiance measured by the PEP ' $87 \mathrm{Kipp} \&$ Zonen $\mathrm{CM} 11-4$ and a primary absolute cavity radiometer plus pyranometer with a shading disk. This dependence is somewhat surprising since approximately 93\% of the total irradiance is in the direct component. Referring to the global fixed-tilt uncertainty analysis in Table 2-2, it appears as if this difference is because of an estimated $3^{\circ}$ error in the plane-of-measurement to sun-angle for the PV sample and reference detector used to measure $E_{t t u}$. This illustrates that it is critical for the PV sample and the pyranometer be to coplanar. For $E_{t u t}$ measured with a cavity radiometer plus a pyranometer with a shading disk, it is also imperitive that the tilt and north-south angles of the PV sample be accurately measured. 
Table 3-5. Summary of $I-V$ Parameters for Reference Devices in Multiple-Cell Packages. Corrected to $25^{\circ} \mathrm{C}, 1000 \mathrm{~W} \mathrm{~m}^{-2}$, and the global reference spectrum.

\begin{tabular}{|c|c|c|c|c|c|c|c|c|}
\hline $\begin{array}{l}\text { Sample } \\
\text { Number }\end{array}$ & $\begin{array}{c}\text { Reference } \\
\text { Device }\end{array}$ & $\begin{array}{l}\text { Light } \\
\text { Source }\end{array}$ & $\begin{array}{l}V_{o c} \\
(\mathrm{~V})\end{array}$ & $\begin{array}{l}I_{s c} \\
(\AA)\end{array}$ & $\begin{array}{l}V_{\max } \\
(\mathrm{V})\end{array}$ & $\begin{array}{l}I_{\max } \\
(\mathrm{A})\end{array}$ & $\begin{array}{l}P_{\max } \\
(\mathrm{W})\end{array}$ & $\begin{array}{l}F F \\
(\%)\end{array}$ \\
\hline $\mathrm{RM}-01$ & $\begin{array}{l}\text { RM-01 } \\
\text { S10 } \\
\text { RM-01 } \\
\text { RC-01 } \\
\text { S10 }\end{array}$ & $\begin{array}{l}X-25 \\
X-25 \\
\text { SPI-SUN } \\
\text { SPI-SUN } \\
\text { SPI-SUN }\end{array}$ & $\begin{array}{l}12.74 \\
12.79 \\
12.577 \\
12.595 \\
12.615\end{array}$ & $\begin{array}{l}0.09127 \\
0.0954 \\
0.091 \\
0.094 \\
0.097\end{array}$ & $\begin{array}{r}10.02 \\
10.27 \\
9.91 \\
9.86 \\
9.81\end{array}$ & $\begin{array}{l}0.07859 \\
0.0801 \\
0.078 \\
0.081 \\
0.084\end{array}$ & $\begin{array}{l}0.7875 \\
0.823 \\
0.77 \\
0.80 \\
0.82\end{array}$ & $\begin{array}{l}67.7 \\
67.4 \\
67.6 \\
67.5 \\
67.4\end{array}$ \\
\hline $\mathrm{RM}-02$ & $\begin{array}{l}\text { RM-02 } \\
\text { S10 } \\
\text { RM-02 } \\
\text { RC-02 } \\
\text { S10 }\end{array}$ & $\begin{array}{l}X-25 \\
X-25 \\
\text { SPI-SUN } \\
\text { SPI-SUN } \\
\text { SPI-SUN }\end{array}$ & $\begin{array}{l}12.84 \\
12.89 \\
12.549 \\
12.585 \\
12.629\end{array}$ & $\begin{array}{l}0.09779 \\
0.1043 \\
0.098 \\
0.100 \\
0.105\end{array}$ & $\begin{array}{l}9.247 \\
9.50 \\
9.33 \\
9.08 \\
9.03\end{array}$ & $\begin{array}{l}0.08186 \\
0.0841 \\
0.079 \\
0.083 \\
0.088\end{array}$ & $\begin{array}{l}0.7570 \\
0.799 \\
0.74 \\
0.75 \\
0.79\end{array}$ & $\begin{array}{l}60.3 \\
59.4 \\
59.9 \\
59.9 \\
60.0\end{array}$ \\
\hline $\mathrm{RM}-03$ & $\begin{array}{l}\text { RM-03 } \\
\text { S01 } \\
\text { RM-03 } \\
\text { RC-03 } \\
\text { S01 }\end{array}$ & $\begin{array}{l}X-25 \\
X-25 \\
\text { SPI-SUN } \\
\text { SPI-SUN } \\
\text { SPI-SUN }\end{array}$ & $\begin{array}{l}0.588 \\
0.591 \\
0.557 \\
0.559 \\
0.561\end{array}$ & $\begin{array}{l}2.809 \\
2.935 \\
2.832 \\
2.879 \\
2.953\end{array}$ & $\begin{array}{l}0.4648 \\
0.4577 \\
0.44 \\
0.43 \\
0.44\end{array}$ & $\begin{array}{l}2.558 \\
2.733 \\
2.605 \\
2.703 \\
2.754\end{array}$ & $\begin{array}{l}1.189 \\
1.250 \\
1.14 \\
1.16 \\
1.20\end{array}$ & $\begin{array}{l}72.0 \\
72.2 \\
72.5 \\
72.3 \\
72.3\end{array}$ \\
\hline RM-04 & $\begin{array}{l}\text { RM-04 } \\
\text { S01 } \\
\text { RM-04 } \\
\text { RC-04 } \\
\text { S01 }\end{array}$ & $\begin{array}{l}X-25 \\
X-25 \\
\text { SPI-SUN } \\
\text { SPI-SUN } \\
\text { SPI-SUN }\end{array}$ & $\begin{array}{l}0.594 \\
0.584 \\
0.557 \\
0.562 \\
0.563\end{array}$ & $\begin{array}{l}2.830 \\
2.946 \\
2.855 \\
2.898 \\
2.973\end{array}$ & $\begin{array}{l}0.461 \\
0.465 \\
0.44 \\
0.44 \\
0.44\end{array}$ & $\begin{array}{l}2.648 \\
2.702 \\
2.664 \\
2.664 \\
2.727\end{array}$ & $\begin{array}{l}1.220 \\
1.255 \\
1.18 \\
1.18 \\
1.21\end{array}$ & $\begin{array}{l}72.6 \\
72.9 \\
72.7 \\
72.7 \\
72.4\end{array}$ \\
\hline$R M-05$ & $\begin{array}{l}\text { RM-05 } \\
\text { S01 } \\
\text { RM-05 } \\
\text { RC-05 } \\
\text { S01 }\end{array}$ & $\begin{array}{l}X-25 \\
X-25 \\
\text { SPI-SUN } \\
\text { SPI-SUN } \\
\text { SPI-SUN }\end{array}$ & $\begin{array}{l}0.553 \\
0.554 \\
0.519 \\
0.518 \\
0.519\end{array}$ & $\begin{array}{l}2.465 \\
2.539 \\
2.484 \\
2.492 \\
2.527\end{array}$ & $\begin{array}{l}0.430 \\
0.448 \\
0.41 \\
0.40 \\
0.41\end{array}$ & $\begin{array}{l}2.286 \\
2.265 \\
2.273 \\
2.316 \\
2.328\end{array}$ & $\begin{array}{l}0.983 \\
1.014 \\
0.92 \\
0.93 \\
0.94\end{array}$ & $\begin{array}{l}72.0 \\
72.1 \\
71.4 \\
71.7 \\
71.9\end{array}$ \\
\hline$R M-06$ & $\begin{array}{l}\text { RM-06 } \\
\text { S01 } \\
\text { RM-06 } \\
\text { RC-06 } \\
\text { S01 }\end{array}$ & $\begin{array}{l}X-25 \\
X-25 \\
\text { SPI-SUN } \\
\text { SPI-SUN } \\
\text { SPI-SUN }\end{array}$ & $\begin{array}{l}0.552 \\
0.556 \\
0.520 \\
0.519 \\
0.519\end{array}$ & $\begin{array}{l}2.470 \\
2.534 \\
2.492 \\
2.473 \\
2.523\end{array}$ & $\begin{array}{l}0.440 \\
0.443 \\
0.41 \\
0.41 \\
0.42\end{array}$ & $\begin{array}{l}2.254 \\
2.300 \\
2.316 \\
2.289 \\
2.242\end{array}$ & $\begin{array}{l}0.991 \\
1.020 \\
0.94 \\
0.93 \\
0.94\end{array}$ & $\begin{array}{l}72.7 \\
72.4 \\
72.2 \\
72.2 \\
71.9\end{array}$ \\
\hline
\end{tabular}


Table 3-6. Absolute Spectral Response for $100 \mathrm{~cm}^{2}$ Reference Cells in Multiple-Cell Packages

\begin{tabular}{|c|c|c|c|c|}
\hline $\begin{array}{c}\lambda \\
(\mathrm{nm})\end{array}$ & $\begin{array}{c}\mathrm{RM}-03 \\
S_{r}(\lambda) \\
\left(\mathrm{A} \mathbf{W}^{-1}\right)\end{array}$ & $\begin{array}{c}\mathrm{RM}-04 \\
S_{r}(\lambda) \\
\left(\mathrm{A} \mathrm{W}^{-1}\right)\end{array}$ & $\begin{array}{c}\mathrm{RM}-05 \\
S_{r}(\lambda) \\
\left(\mathrm{AW}^{-1}\right)\end{array}$ & $\begin{array}{c}\mathrm{RM}-06 \\
S_{r}(\lambda) \\
\left(\mathrm{A} W^{-1}\right)\end{array}$ \\
\hline 380 & 0.0617 & 0.0591 & 0.0355 & 0.0384 \\
\hline 400 & 0.1195 & 0.1152 & 0.0800 & 0.0873 \\
\hline 420 & 0.1623 & 0.1569 & 0.1260 & 0.1355 \\
\hline 440 & 0.1899 & 0.1851 & 0.1583 & 0.1685 \\
\hline 460 & 0.2180 & 0.2147 & 0.1896 & 0.2000 \\
\hline 480 & 0.2461 & 0.2438 & 0.2205 & 0.2304 \\
\hline 500 & 0.2649 & 0.2636 & 0.2424 & 0.2512 \\
\hline 520 & 0.2851 & 0.2836 & 0.2643 & 0.2721 \\
\hline 540 & 0.3059 & 0.3049 & 0.2875 & 0.2942 \\
\hline 560 & 0.3286 & 0.3279 & 0.3085 & 0.3141 \\
\hline 580 & 0.3443 & 0.3439 & 0.3254 & 0.3298 \\
\hline 600 & 0.3624 & 0.3622 & 0.3473 & 0.3505 \\
\hline 620 & 0.3830 & 0.3843 & 0.3718 & 0.3721 \\
\hline 640 & 0.3927 & 0.3940 & 0.3766 & 0.3773 \\
\hline 660 & 0.4109 & 0.4122 & 0.3939 & 0.3928 \\
\hline 680 & 0.4230 & 0.4250 & 0.4044 & 0.4021 \\
\hline 700 & 0.4342 & 0.4377 & 0.4165 & 0.4124 \\
\hline 725 & 0.4596 & 0.4627 & 0.4329 & 0.4290 \\
\hline 750 & 0.4759 & 0.4796 & 0.4424 & 0.4373 \\
\hline 775 & 0.4917 & 0.4957 & 0.4516 & 0.4448 \\
\hline 800 & 0.4963 & 0.5006 & 0.4490 & 0.4415 \\
\hline 825 & 0.5199 & 0.5251 & 0.4620 & 0.4546 \\
\hline 850 & 0.5170 & 0.5231 & 0.4483 & 0.4418 \\
\hline 877 & 0.5295 & 0.5367 & 0.4476 & 0.4397 \\
\hline 900 & 0.5207 & 0.5291 & 0.4280 & 0.4193 \\
\hline 927 & 0.5102 & 0.5202 & 0.4047 & 0.3957 \\
\hline 950 & 0.4963 & 0.5081 & 0.3789 & 0.3698 \\
\hline 977 & 0.4562 & 0.4693 & 0.3320 & 0.3235 \\
\hline 1000 & 0.4052 & 0.4188 & 0.2790 & 0.2726 \\
\hline 1026 & 0.3232 & 0.3365 & 0.2137 & 0.2095 \\
\hline 1050 & 0.2566 & 0.2692 & 0.1555 & 0.1556 \\
\hline 1075 & 0.2232 & 0.2350 & 0.1260 & 0.1275 \\
\hline 1100 & 0.1857 & 0.1958 & 0.0969 & 0.0984 \\
\hline 1150 & 0.0951 & 0.0990 & 0.0269 & 0.0273 \\
\hline 1200 & 0.0030 & 0.0031 & 0.0016 & 0.0015 \\
\hline Light bias: & $200.0 \mathrm{~mA}$ & $200.0 \mathrm{~mA}$ & $200.0 \mathrm{~mA}$ & $200.0 \mathrm{~mA}$ \\
\hline
\end{tabular}




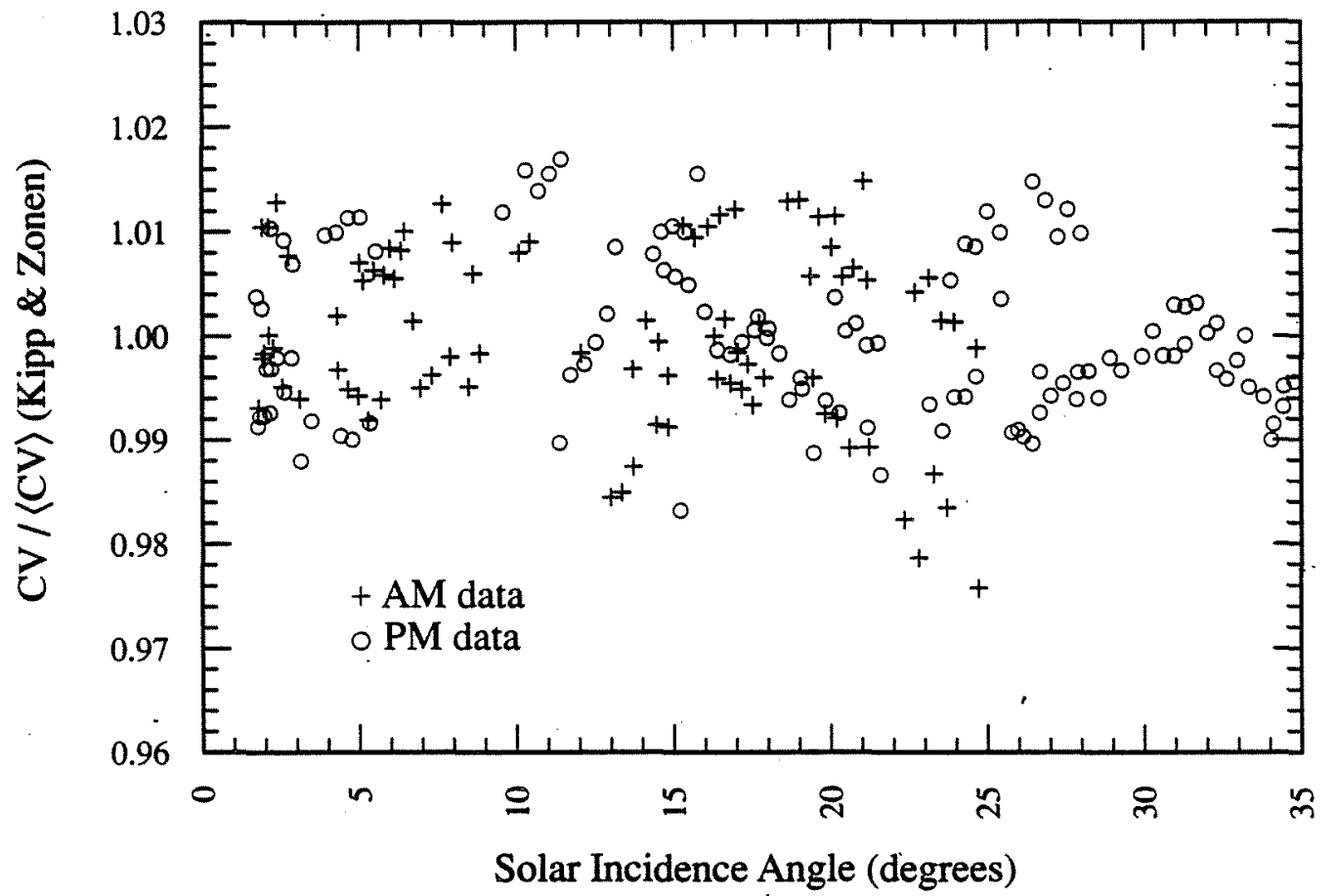

Figure 3-4. $C V /\langle C V\rangle$ vs. Solar Incidence Angle for $E_{\text {tot }}$ Measured Using the PEP '87 Kipp \& Zonen Pyranometer

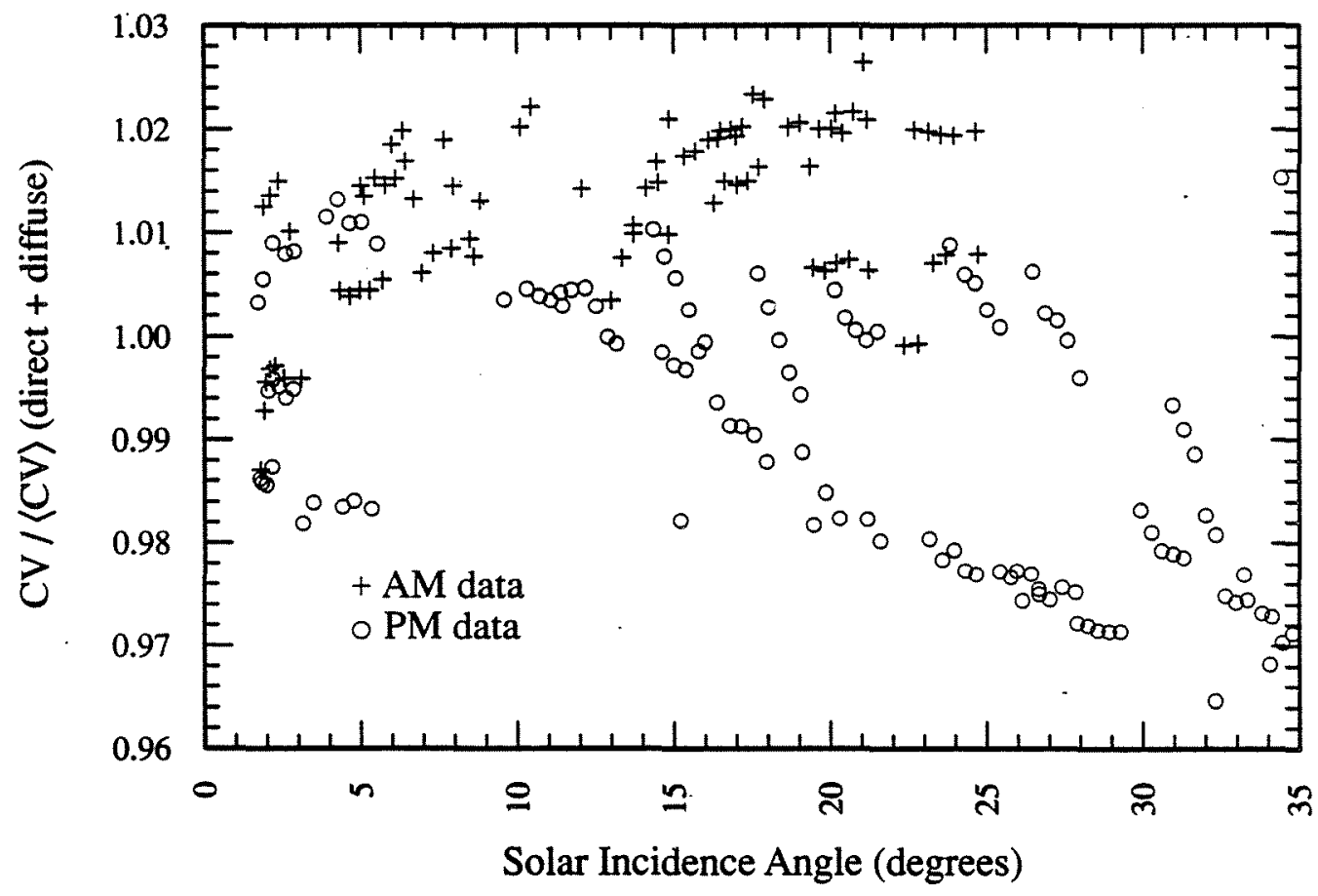

Figure 3-5. $C V /\langle C V\rangle$ vs. Solar Incidence Angle for $E_{\text {tot }}$ Measured Using the Direct-Plus-Diffuse Method 


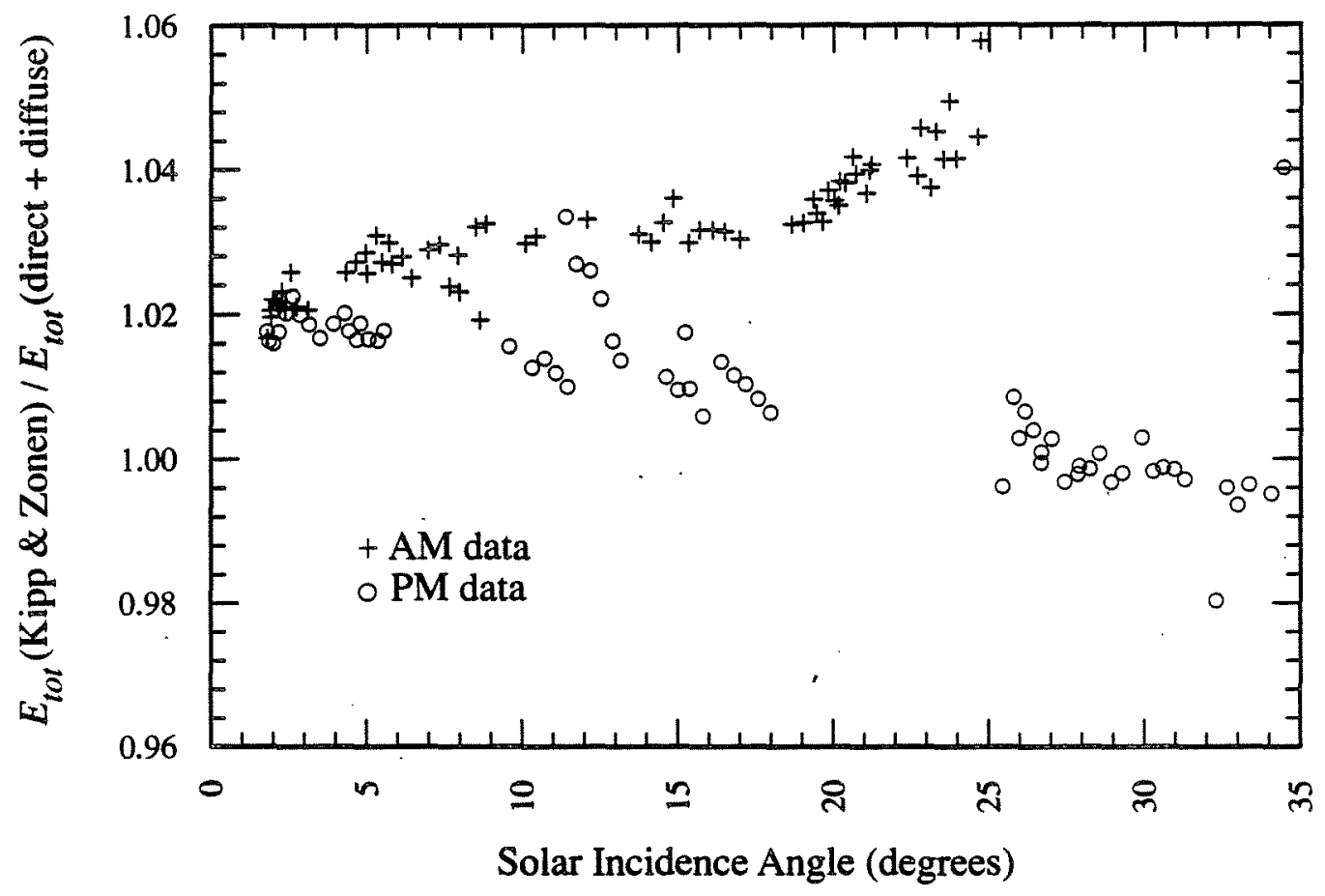

Figure 3-6. Total Irradiance Ratio Above and to the East of the Global Fixed-Tilt Sample Plane as a Function of Solar Incidence Angle (See Figure 2-13) 


\subsection{Reference Modules}

\subsubsection{Data Summary}

The calibration values for the PEP ' 87 reference modules using the global fixed-tilt and simulator methods are summarized in Table 3-7 and Tables B-3 to B-8. Tables C-1 to C-6 also give the $I-V$ characteristics for the RM-series devices measured with the Spire SPI-SUN simulator. The corresponding RC-series (reference cell in a single-cell package) spectral responses (Table 3-2) were used to determine the spectral correction factors $k$ and the spectral mismatch errors $M$. The uncorrected calibration values $C V_{U}$ were corrected to $25^{\circ} \mathrm{C}$ using the temperature coefficients given in Table 3-3 for the cells (RC-series) because of the smaller uncertainty. Table 3-8 compares the $I-V$ characteristics of the RC-and RM-series reference devices calibrated using the global fixed-tilt method to measurements obtained with the Spire SPI-SUN set to the SERI primary direct-normal reference cells SO1 and S10.

\subsubsection{Discussion}

The data in Table 3-7 are within the mutual estimated $U_{95}$ uncertainties from section 2.6 for the global fixed-tilt and simulator calibration methods $( \pm 4 \%)$. The normalized and corrected calibration values in Figure 3-4 and Figure 3-5 include both the RC- and RM- series reference devices. The major difference, ignoring spectral response, between a single cell in a multiple-cell package and a module of the same type is the area. As the module area increases, any errors due to field-of-view and leveling (discussed in Section 4.1.1) increase for outdoor calibrations, and errors due to spatial nonuniformity increase for solar simulator measurements.

Table 3-7. Summary of $I_{s c}$ Calibrations (amperes) for Reference Modules. Corrected to $25^{\circ} \mathrm{C}, 1000 \mathrm{Wm}^{-2}$, and the global reference spectrum.

\begin{tabular}{|c|c|c|c|c|c|}
\hline \multirow[t]{2}{*}{ Sample } & \multicolumn{2}{|c|}{ Global Fixed-Tilt } & \multicolumn{3}{|c|}{ SPI-SUN Simulator with Reference Device } \\
\hline & $\begin{array}{c}\text { Pyranometer } \\
U_{95}=4.3 \%\end{array}$ & $\begin{array}{c}\text { Direct + Diffuse } \\
U_{95}=3.3 \%\end{array}$ & $\begin{array}{l}\text { S01 or S10 } \\
U_{95}=3.0 \%\end{array}$ & $\begin{array}{c}\text { RC-0x } \\
U_{95}=4.7 \%\end{array}$ & $\begin{array}{c}\mathrm{RM}-0 \mathrm{x} \\
U_{95}=4.7 \%\end{array}$ \\
\hline SM-01 & 0.4583 & 0.4676 & 0.5164 & 0.495 & 0.486 \\
\hline $\mathrm{SM}-02$ & 0.4799 & 0.4890 & 0.5248 & 0.4988 & 0.4922 \\
\hline SM-03 & 2.819 & 2.871 & 2.891 & 2.836 & 2.781 \\
\hline SM-04 & 2.824 & 2.872 & 2.938 & 2.855 & 2.805 \\
\hline SM-05 & 2.473 & 2.519 & 2.586 & 2.543 & 2.559 \\
\hline SM-06 & 2.451 & 2.487 & 2.586 & 2.531 & 2.570 \\
\hline
\end{tabular}


Table 3-8. Summary of $I-V$ Parameters for Reference Modules (at $25^{\circ} \mathrm{C}, 1000 \mathrm{Wm}^{-2}$, and the global reference spectrum)

\begin{tabular}{|c|c|c|c|c|c|c|c|c|}
\hline $\begin{array}{l}\text { Sample } \\
\text { Number }\end{array}$ & $\begin{array}{c}\text { Reference } \\
\text { Device }\end{array}$ & $\begin{array}{l}\text { Light } \\
\text { Source }\end{array}$ & $\begin{array}{l}V_{w} \\
(\mathrm{~V})\end{array}$ & $\begin{array}{l}I_{s c} \\
(\mathrm{~A})\end{array}$ & $\begin{array}{l}V_{\max } \\
(\mathrm{V})\end{array}$ & $\begin{array}{l}I_{\text {max }} \\
(\mathrm{A})\end{array}$ & $\begin{array}{l}P_{\max } \\
(\mathrm{W})\end{array}$ & $\begin{array}{l}F F \\
(\%)\end{array}$ \\
\hline \multirow[t]{3}{*}{$\mathrm{SM}-01$} & $\mathrm{RM}-01$ & SPI-SUN & 38.995 & 0.486 & 27.25 & 0.373 & 10.16 & 53.6 \\
\hline & $\mathrm{RC}-01$ & SPI-SUN & 38.932 & 0.495 & 27.3 & 0.380 & 10.37 & 53.8 \\
\hline & $\mathrm{S} 10$ & SPI-SUN & 39.098 & 0.5164 & 27.3 & 0.395 & 10.78 & 53.4 \\
\hline \multirow[t]{3}{*}{$S M-02$} & $\mathrm{RM}-02$ & SPI-SUN & 39.036 & 0.4922 & 27.05 & 0.372 & 10.06 & 52.4 \\
\hline & $\mathrm{RC}-02$ & SPI-SUN & 39.108 & 0.4988 & 27.25 & 0.376 & 10.24 & 52.5 \\
\hline & $\mathrm{S} 10$ & SPI-SUN & 39.158 & 0.5248 & 27.64 & 0.389 & 10.75 & 52.3 \\
\hline \multirow[t]{3}{*}{$\mathrm{SM}-03$} & $\mathrm{RM}-03$ & SPI-SUN & 21.138 & 2.781 & 17.29 & 2.633 & 45.51 & 77.4 \\
\hline & $\mathrm{RC}-03$ & SPI-SUN & 21.050 & 2.836 & 17.58 & 2.621 & 46.07 & 77.2 \\
\hline & S01 & SPI-SUN & 21.359 & 2.891 & 17.58 & 2.723 & 47.86 & 77.5 \\
\hline \multirow[t]{3}{*}{$S M-04$} & $R M-04$ & SPI-SUN & 21.205 & 2.805 & 17.58 & 2.602 & 45.74 & 76.9 \\
\hline & $\mathrm{RC}-04$ & SPI-SUN & 21.149 & 2.855 & 17.48 & 2.648 & 46.29 & 76.7 \\
\hline & S01 & SPI-SUN & 21.282 & 2.938 & 17.48 & 2.723 & 47.60 & 76.1 \\
\hline \multirow[t]{3}{*}{$\mathrm{SM}-05$} & $\mathrm{RM}-05$ & SPI-SUN & 10.850 & 2.559 & 8.55 & 2.336 & 19.96 & 71.9 \\
\hline & $\mathrm{RC}-05$ & SPI-SUN & 10.903 & 2.543 & 8.69 & 2.309 & 20.07 & 72.4 \\
\hline & S01 & SPI-SUN & 10.902 & 2.586 & 8.69 & 2.340 & 20.34 & 72.1 \\
\hline \multirow[t]{3}{*}{$\mathrm{SM}-06$} & RM-06 & SPI-SUN & 10.685 & 2.570 & 8.40 & 2.328 & 19.55 & 71.2 \\
\hline & $\mathrm{RC}-06$ & SPI-SUN & 10.720 & 2.531 & 8.45 & 2.301 & 19.44 & 71.6 \\
\hline & S01 & SPI-SUN & 10.822 & 2.586 & 8.45 & 2.379 & 20.10 & 71.8 \\
\hline
\end{tabular}




\subsection{DISCUSSION OF PV CALIBRATION METHODS}

\subsection{Proposed IEC Global Calibration Method}

This section discusses the merits and problems of the proposed IEC calibration method as specified for the PEP ' 87 intercomparison in Table A-1, and its suitability for use as an international standard for the calibration of terrestrial PV devices. Because a consensus has not been reached on the desired level of uncertainty for the global method, this section will discuss the estimated uncertainties in the various aspects of this method.

\subsubsection{Air Mass, Elevation Angle, and Angle of Incidence}

The proposed IEC global calibration method requires that both the solar air mass be between AM1 and AM2 for crystalline silicon devices, and between AM1 and AM1.5 for amorphous silicon and other thin-film devices, and that a "sun-facing platform" be used. No distinction is made between global-normal and global fixed-tilt, even though the two configurations are different. The air mass requirement appears to be irrelevant if spectral corrections are carried out. If the air mass constraint is meant to restrict the time-of-day that data should be taken, then a constraint on the azimuth and the plane-of-measurement to sun angle would be more appropriate, such as restricting the azimuthal angle $\phi$ to less than $\pm 20^{\circ}$. The pressure-corrected optical air mass is important for Rayleigh scattering as it is a function of the number of air molecules encountered, while the relative optical air mass is used in aerosol optical depth determinations. By itself, air mass is not sufficient to ensure a small spectral mismatch for outdoor calibrations.

Although Table A-1 limits the elevation angle to values greater than $54^{\circ}$ for global-horizontal calibrations, it would seem from SERI's results of this intercomparison that the incidence angle (defined by Figure 2-11) should be less than $20^{\circ}$. This constraint would replace the minimum $54^{\circ}$ solar elevation requirement for global-horizontal and provide an appropriate restriction for global fixed--tilt calibrations, which are not discussed in the IEC global method. The $20^{\circ}$ incidence angle constraint for all global calibrations is based on limiting the error due to misalignment to less than $\pm 3^{\circ}$. Because the pyranometer leveling bubble covers a $1^{\circ}$ range and the pyranometer thermopile is typically within $\pm 1^{\circ}$ of being coplanar of the bubble, and the PV sample plane is restricted to be within $\pm 2^{\circ}$ of the pyranometer leveling bubble, $\mathrm{a} \pm 3^{\circ}$ error is certainly possible. If the total irradiance is measured with a cavity radiometer plus a pyranometer for the diffuse, a similar error can occur because the cavity radiometer reading must be multiplied by the cosine of the incidence angle. The magnitude of possible errors in the measured total irradiance due to positive leveling errors is shown graphically in Figure 4-1, which correspond to the south-facing $60^{\circ}$ fixed-tilt PV calibration conditions on December 1, 1988 at SERI. The error in measuring the total irradiance is insensitive to the error in the tilt $\Psi$ but is very sensitive to the east-west alignment $\gamma$. The sign of the error is reversed for a negative error in $\gamma$, and the error is offset about $+0.2 \%$ for a negative error in $\Psi$. Because the form of Figure $4-1$ is very similar to the fixed-tilt PV calibrations and total irradiance 


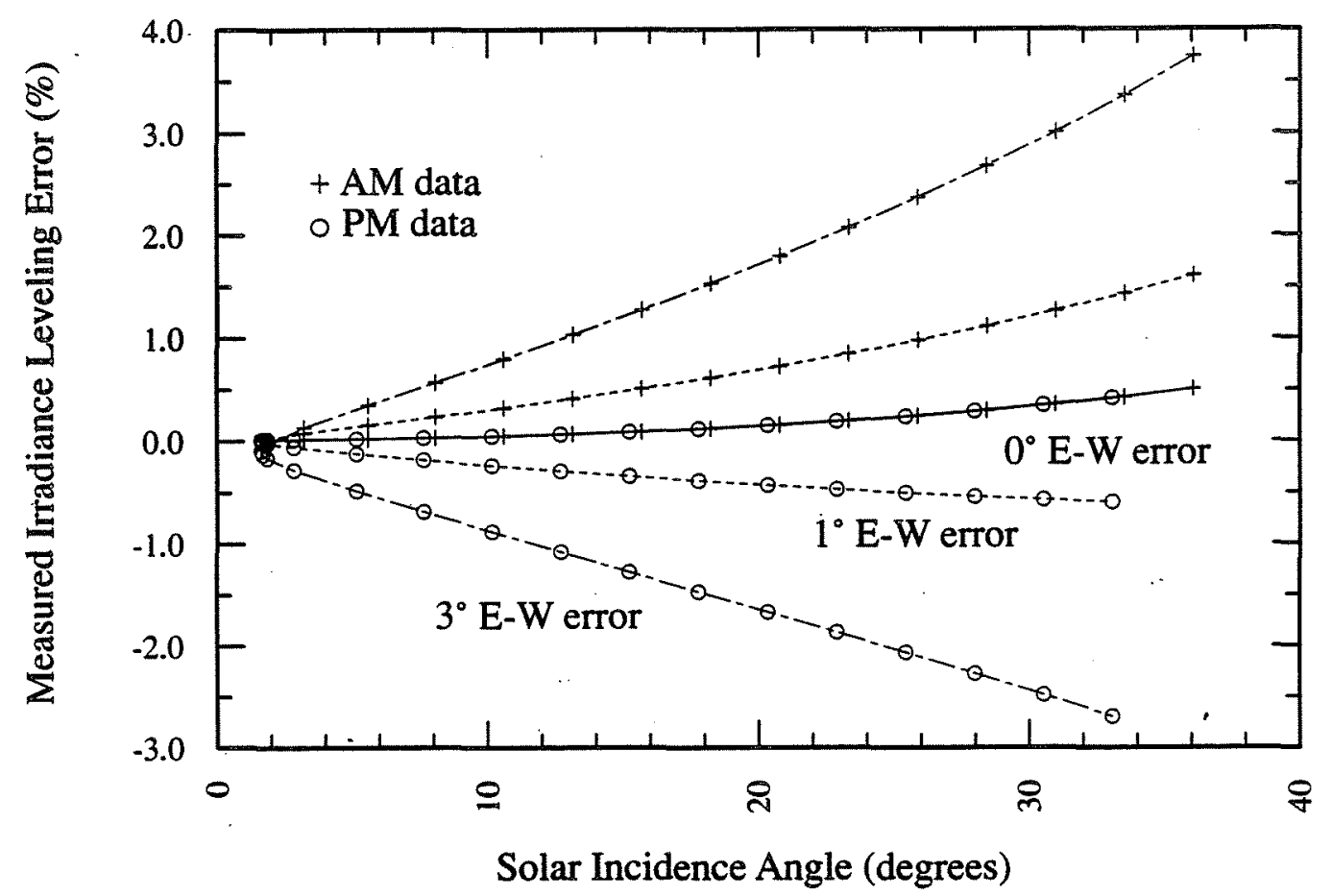

Figure 4-1. Possible Error in Total Irradiance Due to Misalignment (calculated)

measurements shown in Figures 3-5 and 3-6, it is possible for leveling errors in the total irradiance to be misinterpreted as a deviation from an ideal cosine response of a device or a pyranometer.

Many of the merits and problems of global calibration methods are associated with the field-of-view in general and specifically with the angularly-resolved diffuse component. The computer model that generated the global reference spectrum [19] actually calculated the angular dependence of the diffuse component, but then lumped the spectral irradiance into a single value at each wavelength. The diffuse component can be properly treated for the global or direct-normal calibration procedures using Eq. 2-9. Unfortunately, Eq. 2-9 is too complicated for most laboratories to implement because the angularly resolved spectral response and spectral irradiance are very difficult to measure. Additionally, pyranometers are assumed to have an ideal cosine response, which is an incorrect assumption.

\subsubsection{Sample Interval}

The IEC global method requires that five readings be taken in quick succession until $C V_{U}\left(I_{s c} / E_{t o t}\right)$ varies by less than $1 \%$. The term "quick succession" is vague and in fact some data acquisition systems can record data at a rate exceeding 50,000 readings per second, while others take as much as three seconds for a single reading. The difference in the uncertainty between these two measurements is substantial. For the $\pm 1 \%$ stability requirement to be valid, the five successive sets of readings should be longer than several time-constants of the instrument used to measure $E_{t o t}$. As 
a minimum, the five readings should be over at least a three minute time period. If the five successive sets of readings are performed at the same time-of-day on three days, then errors due to leveling, incidence angle, and field-of-view will not be readily observable. Also, many random and nonrandom calibration error sources will not be detectable in the experimental data if the sample interval is too short.

A more subtle problem associated with the sample interval is the device temperature. If the sample is kept shaded prior to the measurement and exposed to sunlight just before the data is taken, as is required for the global method described in Appendix A, then the PV device will not be in thermal equilibrium. This means that the device temperature is changing while the data are being collected, and the PV device temperature will not be in thermal equilibrium with the package or thermocouple temperature. Because the $I_{s c}$ temperature corrections are less than $3 \%$ for the PEP ' 87 devices, the total measurement uncertainty should be lower if the devices are not shaded and are allowed to attain thermal equilibrium with the surroundings.

\subsubsection{Ground Reflections and Ground Albedo}

The proposed global sunlight method for a nonhorizontal test plane ( $\Psi>0$ in Figure $2-11$ ) requires that the ground reflections as measured with a pyranometer be less than $3 \%$. The ground reflectance was measured directly at SERI by subtracting the plane-of-measurement diffuse irradiance from the diffuse irradiance with a flat-black field-of-view shield installed so that ground reflections were minimized. The percent of plane-of-measurement irradiance due to ground reflections is therefore

$$
R=100 * \frac{E_{\text {diffuse }}(\text { unshielded })-E_{\text {diffuse }} \text { (shielded) }}{E_{\text {tot }}}
$$

where $E_{\text {diffuse }}$ refers to the ground irradiance measured with unshielded and shielded pyranometers. The ground reflection contribution to the plane-of-measurement total irradiance was $1.3 \%$ for the global-normal site (Figure 2-15) without a false horizon, and below $0.1 \%$ with the false horizon, which was a 1.2 by $2.4 \mathrm{~m}$ board painted flat-black. The calculated ground irradiance was $2.7 \%$ of the total irradiance. The measured ground reflection contribution for the fixed-tilt site (Figure 2-12) was $0.8 \%$.

For simplicity, the ground reflection contribution was measured in only one location in the plane-of-measurement. The assumption that the ground is a homogeneous Lambertian surface (perfect diffuser) is probably not valid [35], which is verified by the site photographs, Figures 2-12 and 2-14. An alternative to measuring the reflectance would be to require that the variation in irradiance over the plane-of-measurement be less than $\pm 1 \%$. This could be accomplished by dividing the short-circuit current of the center cell by the short-circuit current of a perimeter cell at several locations. The time-of-day dependence, Figures 3-5 and 3-6, is characteristic of changing uniformity over the plane-of-measurement. Unfortunately, this could also be due to misalignment and cosine-related errors. 
The isotropic sky model $[35,36]$ gives $R$ as

$$
R=100 * \frac{0.5 * E_{\text {global }} * \rho *\{1-\cos (\Psi)\}}{E_{\text {tot }}}
$$

where $E_{\text {global }}$ is the total global irradiance on a horizontal surface, $\Psi$ is the tilt angle, and $\rho$ is the ground albedo. Using this equation, a ground albedo of 0.23 was determined from the ratio of the total ground irradiance for a pyranometer facing the ground at an elevation of five feet above the ground to $E_{\text {global }}$. This value is typical of dry brush [36].

\subsubsection{Total Irradiance}

The proposed calibration method requires a class 1 pyranometer, calibrated outdoors against a primary absolute cavity radiometer, to measure the total irradiance. Using a cavity radiometer to measure the direct component and a shaded pyranometer to measure the diffuse component should also be allowed. The uncertainty is approximately $25 \%$ lower if a cavity radiometer is used instead of a pyranometer to measure $E_{t o}$, and the data are thus closer to the World Radiometric Reference. The two methods of measuring $E_{t o t}$ and their effect on the calibration value are compared in Tables $3-1,3-4$, and 3-7. Another important advantage of using a cavity radiometer is that real-time information on the direct-to-diffuse ratio can be obtained.

\subsubsection{Integration Limits}

There are no constraints specified in Table A-1 on the integration limits for the spectral correction factor. As the upper and lower wavelength limits of the spectral correction factor integrations approach each other, $C V_{U}$ and $C V$ become identical: In this case, the source and reference spectral irradiances must be assumed to be identical outside the limits of integration. in order for the $C V$ integrations (Eqs. 2-9, 2-10, and in Table A-1) to balance, outside of the integration limits the total irradiance must be equal to the integral of the reference spectral irradiance, and the wavelength limits for all four integrals must be identical. Table $4-1$ shows the effect of changing the integration limits on the standard deviation of the spectral correction factor. The samples in Table 4-1 are the SERI reference cells that were used in the intercomparison. The direct-normal calibration spectra were used because the integration limits could be extended to cover the entire reference spectrum (see Reference 12). This was not possible for the global calibrations, because a model that can accurately extend measured global spectral irradiance data to cover the entire 300 to $4000 \mathrm{~nm}$ range is not available. The application of spectral correction factors reduced the standard deviation of the calibration values for all of the SERI and PEP ' 87 devices in this study when the standard deviation of the uncorrected calibration value was greater than $0.8 \%$. The limits of integration for the global calibrations in this study were 340 to $1100 \mathrm{~nm}$. 
Table 4-1. Effect of Changing Integration Limits on the Spectrally-Corrected Calibration Value. The calibration value is for the global reference spectrum at $25^{\circ} \mathrm{C}$

\begin{tabular}{|c|c|c|c|c|c|c|}
\hline \multirow[b]{2}{*}{$\begin{array}{l}\text { Spectral correction } \\
\text { integration limits }\end{array}$} & \multicolumn{2}{|l|}{ S01 } & \multicolumn{2}{|c|}{ DSET-026 } & \multicolumn{2}{|l|}{ S10 } \\
\hline & $\begin{array}{c}\langle C V\rangle \\
\left(\mathrm{mAW}^{-1} \mathrm{~m}^{2}\right)\end{array}$ & $\begin{array}{l}2 \sigma \\
(\%)\end{array}$ & $\begin{array}{c}\langle C V\rangle \\
\left(\mathrm{mAW}^{-1} \mathrm{~m}^{2}\right)\end{array}$ & $\begin{array}{l}2 \sigma \\
(\%)\end{array}$ & $\begin{array}{c}\langle C V\rangle \\
\left(\mathrm{mAW}^{-1} \mathrm{~m}^{2}\right)\end{array}$ & $\begin{array}{l}2 \sigma \\
(\%)\end{array}$ \\
\hline
\end{tabular}

Direct-normal calibration (cavity radiometer, $5^{\circ}$ field-of-view)

\begin{tabular}{lllllll} 
no correction & 0.1299 & 0.54 & 0.1027 & 0.08 & 0.04526 & 0.59 \\
$340-1100 \mathrm{~nm}$ & 0.1287 & 0.47 & 0.1020 & 0.12 & 0.04525 & 0.37 \\
$300-4000 \mathrm{~nm}$ & 0.1282 & 0.76 & 0.1017 & 0.45 & 0.04484 & 0.49 \\
\hline
\end{tabular}

\begin{tabular}{lllllll}
\hline$:$ & \multicolumn{7}{c}{ Global-normal calibration (cavity radiometer + shaded pyranometer) } \\
no correction & 0.1273 & 1.21 & 0.1023 & 1.33 & 0.04292 & 1.28 \\
$400-1100 \mathrm{~nm}$ & 0.1268 & 1.16 & 0.1014 & 1.13 & 0.04371 & 1.10 \\
$380-1100 \mathrm{~nm}$ & 0.1266 & 1.10 & 0.1013 & 1.06 & 0.04365 & 1.09 \\
$360-1100 \mathrm{~nm}$ & 0.1266 & 1.01 & 0.1014 & 0.98 & 0.04362 & 1.05 \\
$340-1100 \mathrm{~nm}$ & 0.1267 & 0.92 & 0.1017 & 0.90 & 0.04367 & 1.00 \\
\hline
\end{tabular}

\subsubsection{Determination of the Spectral Correction Factor}

The global method requires that the spectral correction factor be multiplied by the mean of the uncorrected calibration values for a single day. In reality, the spectral irradiance should be measured at the same time as each $C V_{U}$ since this assumption was made in the derivation of the equations for the calibration value (Eqs. 2-9 and 2-10). The global-normal and direct-normal calibration methods recorded $30 \mathrm{CV}_{U} \mathrm{~s}$ during the $30 \mathrm{sec}$ measurement period of the spectroradiometer. The global method also allows the spectral irradiance to be measured "immediately after each day's calibration." Table 4-2 summarizes the additional error that would have been introduced in the SERI PEP '87 intercomparison calibrations if this procedure were used. The net effect can be seen as a bias of the spectral correction factor toward the extreme values. The data in Table 4-2 include all of the 104 spectral irradiances measured for the global-normal calibration method. Similar results were obtained for the global fixed-tilt calibration method. If the spectral correction factor based upon measurements at the end of the day are used, then errors in the corrected calibration value greater than the spectral calibration itself could be introduced. Finally, the proposed method states that "....if facilities for spectral irradiance are not available, $k$ may be established from spectrally-corrected calibrations of the reference devices carried out by a competent agency. Round-Robin exercises could be used to this end." The application of a spectral correction factor in this manner would negate 
the traceability of the data to the. World Radiometric Reference and the calibration would, in fact, no longer be a primary calibration because the correction factor would become an empirically-derived correction factor accounting for a given laboratory's bias and precision error.

Nonideal spectroradiometer cosine response is not easily detected. Because the fixed-tilt spectral irradiance was measured over a range of solar incidence angles using two LI-1800 spectroradiometers, one with a Teflon dome and the other with an integrating sphere, as shown in Figure 4-2, differences in cosine response could be seen. In Figure 4-2, the ratio of the spectral correction factor $k$ calculated using the Teflon dome to the integrating sphere data is plotted versus the incidence angle for a single-crystal silicon ( $\mathrm{RC}-03$, Table 3-2) and an amorphous silicon (RC-01, Table 3-2) reference cell.

Table 4-2. Range of Values of the Spectral Correction Factor $\boldsymbol{k}$ (includes all 104 spectral irradiances measured at the time of the PEP ' 87 calibrations over a period of four days)

\begin{tabular}{lccccc}
\hline \multirow{2}{*}{ Sample } & \multicolumn{2}{c}{ Range } & & \multicolumn{2}{c}{ After Each Day } \\
\cline { 2 - 3 } \cline { 5 - 6 } RC-01 & High & Low & & High & Low \\
RC-02 & 1.0344 & 0.9997 & & 1.0344 & 1.0116 \\
RC-03 & 1.0329 & 0.9989 & & 1.0329 & 1.0116 \\
RC-04 & 1.0010 & 0.9783 & & 1.0010 & 0.9789 \\
RC-05 & 1.0055 & 0.9784 & & 1.0055 & 0.9797 \\
RC-06 & 1.0080 & 0.9789 & & 1.0080 & 0.9816 \\
RC-07 & 1.0078 & 0.9771 & & 0.9971 & 0.9771 \\
RC-08 & 1.0072 & 0.9773 & & 1.0072 & 0.9791 \\
\hline
\end{tabular}

\subsubsection{Uncertainty}

In determining the most appropriate calibration method, the desired level of uncertainty must be established. Procedures that may be more difficult or costly to implement but are more accurate should be allowed if their accuracy can be independently determined by intercomparisons and uncertainty analyses. It should be noted that the uncertainty in the various calibration procedures is composed of both random and nonrandom errors, and the nonrandom errors cannot be estimated statistically. From the SERI results for the PEP' 87 intercomparison, the global method which has the lowest uncertainty is the global-normal method (Table 2-3) using a cavity radiometer to measure the direct irradiance and a shaded pyranometer to measure the diffuse irradiance, along with spectral and temperature corrections for each data point. The highest uncertainty of about $\pm 10 \%$ would correspond to a $54^{\circ}$ solar elevation angle ( $36^{\circ}$ solar incidence angle), a single spectral correction factor applied to the average of each day's set of uncorrected calibration values, $3 \%$ ground reflections, a diffuse to total irradiance ratio of 0.25 , and a class 1 pyranometer. It is assumed that 


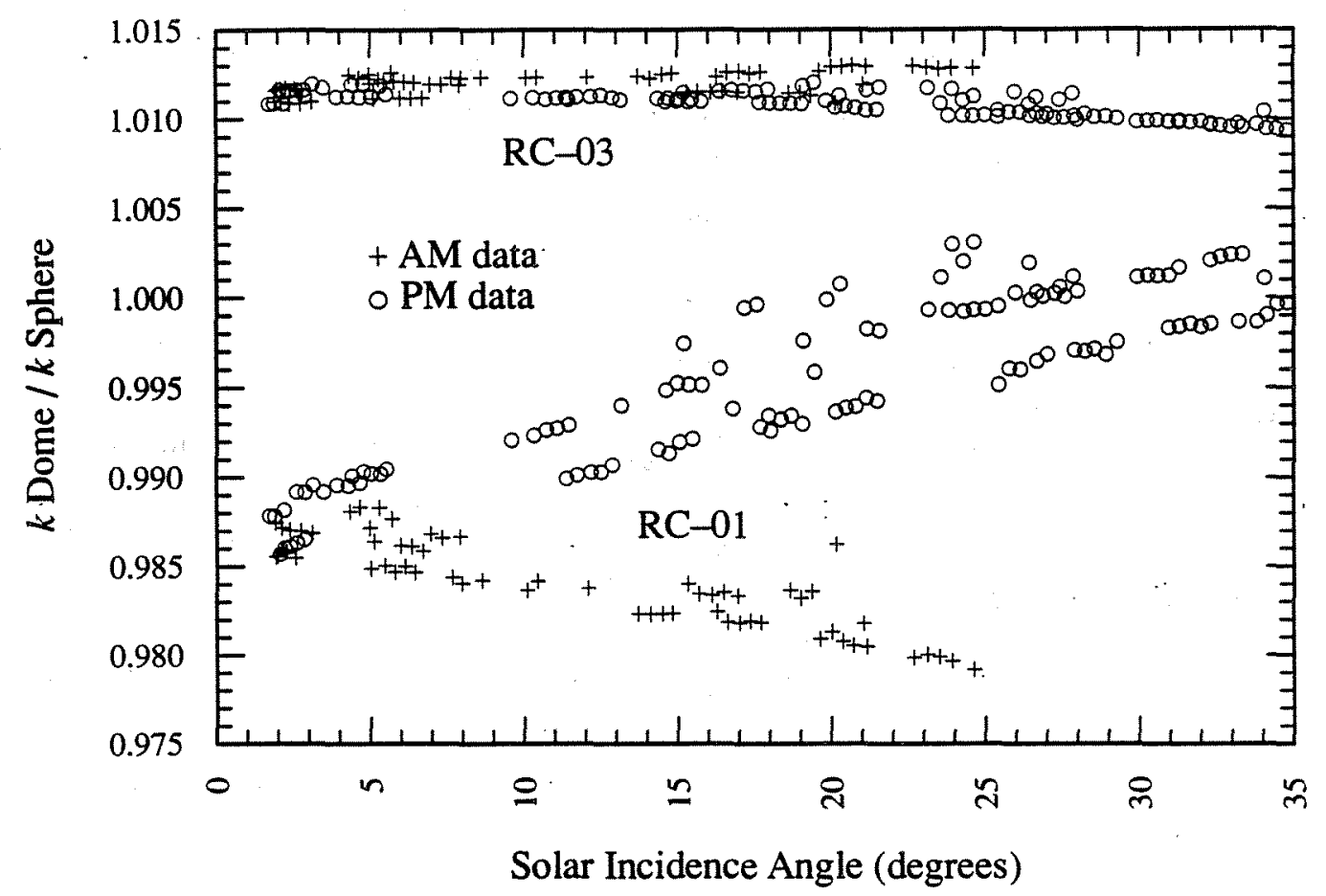

Figure 4-2. Ratio of Spectral Correction Factor Determined with Teflon Dome to Integrating Sphere vs. Solar Incidence Angle

because the proposed IEC global method makes no mention of the uncertainty introduced into the data acquisition system by noise, load resistors, temperature coefficients of the electronics, or thermal voltages, these sources of error are therefore negligible, even though many of the these error sources are nonrandom and will not affect the standard deviation. A realistic upper limit for the uncertainty in the proposed IEC global method would be a bias error of $8 \%$ and a random error ( 1 standard deviation) of $\pm 1 \%$, giving a $U_{95}$ uncertainty of $\pm 8.2 \%$.

For the calibration value to be traceable to the World Radiometric Reference and the global reference spectrum (Table A-1), the spectral irradiance should be measured at the same time as each uncorrected calibration value. If a spectral correction factor is not used, then the calibration value is sample- and site-specific, in addition to being untraceable to any reference spectrum.

\subsection{Global-Horizontal, Global-Normal, and Global Fixed-Tilt Methods}

Section 2.6 discusses the estimated uncertainty for the global-normal and global fixed-tilt calibration methods used at SERI, and Section 3 discusses the global method of calibrating reference devices and the SERI results for the PEP ' 87 intercomparison. One of the commonly used arguments for the global calibration method is that the intended application of photovoltaics is outdoor power generation under global irradiation, which is true from an applications point of view. The global method is at present the only practical outdoor method of calibrating large-area devices such as cells in multiple-cell packages or modules. The uncertainty limit for the proposed IEC global method 
.could be as high as $\pm 10 \%$ for a horizontal surface at $54^{\circ}$ elevation angle using a pyranometer to measure the total irradiance and applying a spectral correction that was not determined at the time of measurement, although $\pm 4 \%$ can be attained with a few restrictions. The $\pm 2.5 \%$ value using the direct-plus-diffuse global-normal method requires a primary absolute cavity radiometer and is therefore probably not available for most laboratories. If an uncertainty in the reference cell calibration of less than $\pm 3 \%$ is desired, then the global method should not be considered. However, if a $\pm 4 \%$ uncertainty is acceptable, then the global method as proposed in Table A-1 is acceptable with some minor revisions. Global-horizontal calibrations reduce field-of-view problems which are probably the most difficult sources of error to quantify. The global-normal method minimizes uncertainties in the the alignment of the the PV sample relative to the sun or pyranometer, while the global fixed-tilt method is convenient, and, near solar noon, the sun is almost at normal incidence. The global calibration method reduces but does not eliminate the spectral sensitivity of the uncorrected calibration value. For calibrations that are traceable to the World Radiometric Reference and the global reference spectrum, spectral corrections must be applied to each data point based upon the measured spectral irradiance at the time of measurement. There are a number of advantages of the global method, most notably minimal size constraints and illumination of the sample with direct-plus-diffuse light.

\subsection{Comparison of Direct and Global Calibration Methods}

SERI currently uses the direct-normal method, as described in section 2.6 .2 and in References 12 , 15,16 , and 18 , to minimize the calibration uncertainty $\left(U_{95}= \pm 0.7 \%\right)$. This method has the additional advantage that $E_{t o t}$ is measured with an absolute cavity radiometer, directly traceable to the World Radiometric Reference. Spectral models have been developed that can automatically extend the measured spectral irradiance to cover the $300-4000 \mathrm{~nm}$ spectral irradiance wavelength range of the global reference spectrum [10]. A disadvantage of the direct-normal calibration method is the restricted sample size, currently $3.3 \mathrm{~cm}$ diameter at SERI, which prohibits the calibration of larger devices. The minimum size of a $5^{\circ}$ field-of-view collimation tube large enough for the PEP ' 87 modules would be $19.7 \mathrm{~m}$ long and $1.7 \mathrm{~m}$ in diameter. Tubes large enough to accommodate the single cells in multiple-cell packages would be about half this size. Although large, commercial Newtonian telescope mounts are capable of tracking tubes of this size to within seconds of arc.

The three SERI primary reference cells used in this study, calibrated using the direct-normal method, have also participated in numerous informal intercomparisons with groups all over the world, including the previous 1985 Summit Round-Robin [1]. Table 4-3 compares the uncorrected and corrected calibration values for the crystalline-silicon and filtered-silicon reference cells that were calibrated at the same time as the other PEP ' 87 samples using the global-normal method (the standard deviation in Table 4-3 was determined from the calibration data), and Table 4-4 lists the spectral response for these devices. The $\pm 1 \%$ agreement between the direct and global calibration methods is well within the estimated uncertainty for the global method (Table 2-3). The generally increasing random error $(2 \sigma=2 R)$ from the direct-normal to the global method is consistent with the uncertainty analysis in Section 2.6 (Table 2-6). 
Table 4-3. Direct vs. Global Calibration Methods.

Corrected to $28^{\circ} \mathrm{C}$ and the global reference spectrum.

\begin{tabular}{llcccc}
\hline Sample & Method & $\begin{array}{c}\left\langle C V_{u}\right\rangle \\
\left(\mathrm{mA} \mathrm{W}^{-1} \mathrm{~m}^{-2}\right)\end{array}$ & $\begin{array}{c}2 \sigma \\
(\%)\end{array}$ & $\begin{array}{c}\langle C V\rangle \\
\left(\mathrm{mA} \mathrm{W}^{-1} \mathrm{~m}^{-2}\right)\end{array}$ & $\begin{array}{c}2 \sigma \\
(\%)\end{array}$ \\
\hline S01 & Direct & 0.1299 & 0.5 & 0.1282 & 0.8 \\
& $\begin{array}{l}\text { Global-normal: } \\
\text { direct + diffuse }\end{array}$ & 0.1274 & 1.0 & 0.1267 & 0.7 \\
& pyranometer & 0.1259 & 1.2 & 0.1253 & 0.9 \\
\hline S10 & Direct & 0.04526 & 0.6 & 0.04484 & 0.5 \\
& Global-normal: & & & 0.04367 & 1.0 \\
& direct + diffuse & 0.04291 & 1.3 & 0.3 & 0.9 \\
& pyranometer & 0.04253 & 1.2 & 0.04377 & 0.4 \\
\hline DSET-026 & Direct & 0.1027 & 0.5 & 0.1017 & 0.4 \\
& Global-normal: & & & 0.1017 & 0.9 \\
& direct + diffuse & 0.1023 & 1.3 & 0.1009 & 0.8 \\
\hline & pyranometer & 0.1014 & 1.2 & & \\
\hline
\end{tabular}


Table 4-4. Absolute Spectral Response for $4 \mathrm{~cm}^{2}$ SERI Primary Reference Cells

\begin{tabular}{|c|c|c|c|}
\hline $\begin{array}{c}\lambda \\
(\mathrm{nm})\end{array}$ & $\begin{array}{c}\text { S01 } \\
S_{r}(\lambda) \\
\left(\mathrm{AW}^{-1}\right)\end{array}$ & $\begin{array}{c}S 10 \\
S_{r}(\lambda) \\
\left(A W^{-1}\right)\end{array}$ & $\begin{array}{c}\text { DSET-026 } \\
S_{r}(\lambda) \\
\left(\mathrm{AW}^{-1}\right)\end{array}$ \\
\hline 380 & 0.1463 & 0.1213 & 0.0404 \\
\hline 400 & 0.1970 & 0.1556 & 0.0748 \\
\hline 420 & 0.2402 & 0.1866 & 0.1221 \\
\hline 440 & 0.2742 & 0.2184 & 0.1616 \\
\hline 460 & 0.3017 & 0.2437 & 0.1996 \\
\hline 480 & 0.3263 & 0.2746 & 0.2318 \\
\hline 500 & 0.3492 & 0.3030 & 0.2611 \\
\hline 520 & 0.3686 & 0.3095 & 0.2849 \\
\hline 540 & 0.3888 & 0.3305 & 0.3095 \\
\hline 560 & 0.4063 & 0.3478 & 0.3303 \\
\hline 580 & 0.4206 & 0.3488 & 0.3468 \\
\hline 600 & 0.4383 & 0.3410 & 0.3653 \\
\hline 620 & 0.4600 & 0.3213 & 0.3867 \\
\hline 640 & 0.4738 & 0.2835 & 0.4016 \\
\hline 660 & 0.4894 & 0.2391 & 0.4166 \\
\hline 680 & 0.5068 & 0.1980 & 0.4325 \\
\hline 700 & 0.5174 & 0.1408 & 0.4441 \\
\hline 725 & 0.5370 & 0.0810 & 0.4633 \\
\hline 750 & 0.5528 & 0.0449 & 0.4776 \\
\hline 775 & 0.5680 & 0.0219 & 0.4914 \\
\hline 800 & 0.5788 & 0.0084 & 0.5009 \\
\hline 825 & 0.5971 & 0.0034 & 0.5157 \\
\hline 850 & 0.5969 & 0.0012 & 0.5153 \\
\hline 900 & 0.6048 & 0.0001 & 0.5097 \\
\hline 950 & 0.5668 & - & 0.4706 \\
\hline 1000 & 0.4510 & - & 0.3553 \\
\hline 1050 & 0.2878 & - & 0.1617 \\
\hline 1100 & 0.1610 & - & 0.0623 \\
\hline 1150 & 0.0495 & - & 0.0146 \\
\hline 1200 & 0.0022 & - & 0.0007 \\
\hline Light bias & $128.2 \mathrm{~mA}$ & $44.8 \mathrm{~mA}$ & $101.7 \mathrm{~mA}$ \\
\hline
\end{tabular}




\subsection{Simulator-Based Secondary Calibrations}

One of the disadvantages of primary reference device calibrations is the time and expense of outdoor measurements. An uncertainty analysis of the SERI Spectrolab X-25 measurements in Table 2-5 predicts that this secondary calibration method has less than half the error of the "primary" global calibration methods if a reference cell with a total uncertainty of less than $\pm 1 \%$ is available. A major goal of the SERI Spectrolab X-25 measurement system is to minimize all sources of bias and precision errors $[15,18]$.

Two methods are employed to demonstrate the utility of simulator calibrations. The first uses a single primary reference cell with a total uncertainty of less than $\pm 1 \%$ and then demonstrates that the calibration value of this device can be obtained within $\pm 1 \%$ using a number of different reference cells, such as single-crystal silicon, polycrystalline-silicon, filtered-silicon, gallium arsenide, or copper indium diselenide $[15,19,29]$. The second method predicts the calibration value of a number of different primary reference cells to within $\pm 1 \%$. This technique was used [29] to experimentally determine the uncertainty between primary terrestrial direct-normal calibrated reference cells (Table 4-3) and primary AM0 reference cells. This technique has also been used to show that the simulator calibration value is virtually independent of the spectral response of the reference cell or spectral irradiance of the light source [15,19]. Figure 4-3 shows the variation in the calibration using a single terrestrial reference cell (sample S01 in this report) and nine primary AM0 reference cells. Table 4-5 shows that eight different terrestrial reference cells can predict the short-circuit current of a single primary AM0 reference cell. The measured difference between the primary calibration method (AM0 or direct-normal) and the simulator calibration method is within the uncertainty of the primary calibration methods.

The simulator-based secondary calibrations for the PEP ' 87 intercomparison of the cells in single-cell packages, Table 3-1, and the reference devices in multiple-cell packages, Table $3-4$, had a lower uncertainty than their corresponding primary global calibrations. The Spire SPI-SUN simulator secondary calibration for the cells in multiple-cell packages (Table 3-4) and the modules (Table 3-7) had an uncertainty comparable to the global calibration uncertainty.

The simulator calibration method is powerful because it can be used to rapidly verify that the primary calibration for a set of reference devices is within their estimated uncertainty. The SERI Spectrolab $\mathrm{X}-25$ system can also detect changes in the reference cell calibration value greater than $1 \%$, which is entirely possible for both filtered-silicon and amorphous silicon reference cells. 
Table 4-5. Measurement of One Primary AM0 Reference Cell with Several Primary Direct-Normal Calibrated Terrestrial Reference Cells. AM0, $1367 \mathrm{Wm}^{-2}$. The primary AM0 calibration for cell D13dd is 157.8 [29].

\begin{tabular}{|c|c|c|c|c|}
\hline \multicolumn{3}{|c|}{ Primary Terrestrial Reference Cell } & \multirow{2}{*}{$\begin{array}{l}\text { Secondary AM0 Current } \\
\text { Using Poly-Si D13dd } \\
(\mathrm{mA})\end{array}$} & \multirow{2}{*}{$\begin{array}{c}\text { AMO } I_{s c} \text { Ratio } \\
(\%)\end{array}$} \\
\hline Device & Type & $\begin{array}{c}\text { Spectral } \\
\text { Mismatch }\end{array}$ & & \\
\hline S01 & $\mathrm{Si}$ & 1.0129 & 158.6 & 0.50 \\
\hline $\mathrm{S} 02$ & $\mathrm{Si}$ & 1.0227 & 157.3 & -0.32 \\
\hline S03 & $\therefore \quad \mathrm{Si}$ & 1.0191 & 157.0 & -0.51 \\
\hline S09 & G5-filtered Si & 0.9518 & 158.8 & 0.63 \\
\hline $\mathrm{S} 10$ & G5-filtered Si & 0.9473 & 159.2 & 0.88 \\
\hline S25 & GaAs & 0.9824 & 159.4 & 1.00 \\
\hline S26 & GaAs & 0.9918 & 157.8 & 0.00 \\
\hline \multirow[t]{2}{*}{ DSET-026 } & $\mathrm{Si}$ & 0.9902 & 159.0 & 0.75 \\
\hline & & & Mean $=158.4$ & 0.37 \\
\hline
\end{tabular}

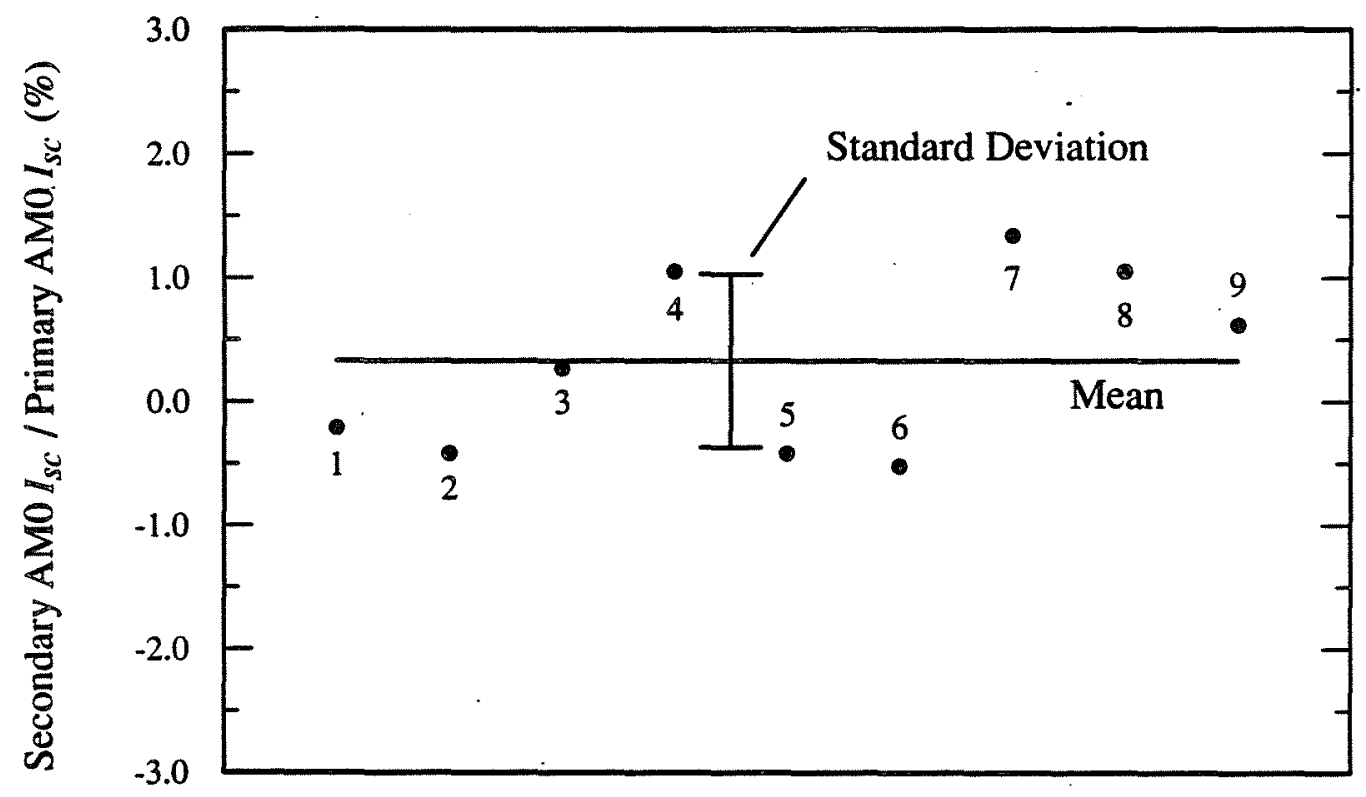

Figure 4-3. Variation in the X-25 Simulator Calibration Values for Nine Primary AM0 Reference Cells (measured with single direct-normal calibrated reference cell S01 [29]) 


\subsection{Reference Device Package Designs}

The three PEP ' 87 intercomparison reference device package designs included a single reference cell in a single-cell package ( $\mathrm{RC}$-devices), a single reference cell in a multiple-cell package (RM-devices), and reference modules (SM-devices). The amorphous silicon reference devices $\mathrm{RC}-01, \mathrm{RC}-02$, $\mathrm{RM}-01$, and $\mathrm{RM}-02$ are not single-cell devices because they are actually several monolithic single-junction cells connected in series.

The single-cell reference device package is similar to the ASTM E 1040 standard package design [37] with the exception of the large thermal mass and cell height. The integral cooling capability can actually increase the error for some measurement systems because the cell sits approximately $2.5 \mathrm{~cm}$ above the back surface; and 10 to $30 \mathrm{~min}$ are required for the cell and package to attain thermal equilibrium, while in ASTM design, the cell rests $0.17 \mathrm{~cm}$ above the back surface and takes about 1 min to reach thermal equilibrium: Many solar simulators have an appreciable spatial nonuniformity above the test plane requiring careful alignment in the vertical direction of the test device and the reference cell. A major application of a single-cell reference device is for setting the irradiance of a solar simulator for a cell held with vacuum on a temperature-controlled plate.

The single reference cell in a multiple-cell package appears to be very useful as a reference device for module measurements. There were no apparent problems with field-of-view or ground reflectance. Two of the devices had thermocouples that were open-circuited upon arrival at SERI. The thermocouple wiring, sheathing, and connectors should be rugged to minimize wire fatigue and breakage. The size of the package was convenient because the Spectrolab X-25 could illuminate all of the sample except the frame corners, yet the short-circuit current allows such a device to be used with most module measurement systems. The short-circuit current for a reference device at standard reporting conditions should be at least $0.1 \mathrm{~A}$ because of the $1 \mathrm{~mA}$ minimum resolution of many module measurement systems. The spectral response of the amorphous silicon devices could not be measured because the monochrometer beam was not large enough to illuminate all 15 series-connected cells in the $\mathrm{RM}-01$ and $\mathrm{RM}-02$ packages.

The modules used in the PEP ' 87 intercomparison did not have any attached temperature sensors, which limits their usefulness as reference devices. If the temperature is not measured at the time of calibration, then the calibration uncertainty will increase by a minimum of $1-2 \%$. The temperature should, therefore, be sampled at several locations and averaged to obtain an effective module temperature.

The primary AM0 reference cells discussed in Section 4.3 were unencapsulated and required vacuum hold-down and probe contacts. Although fragile, this scheme minimizes spatial uniformity errors. 


\subsection{SUMMARY AND RECOMMENDATIONS}

The proposed IEC global calibration method with spectral corrections was found suitable for calibrating reference cells and modules, provided that an uncertainty of $\pm 4 \%$ is acceptable. The $\pm 2.8 \%$ uncertainty limit in the pyranometer calibration will be much higher if the pyranometer is not calibrated under the same environmental conditions as the PV calibrations, or if a primary absolute cavity radiometer is not used. $A \pm 5 \%$ difference in the calibration value between various laboratories using the global method with spectral corrections should be expected. If the spectral irradiance is measured at the end of the day, or a typical spectral correction factor is used, then an even higher uncertainty can be expected. There was no detectable difference in the uncertainty for the primary global calibration of cells or modules.

This report also compares the global method with the SERI primary direct-normal and the NASA primary AM0 calibration methods. The direct-normal method has a verifiable uncertainty of less than $\pm 1 \%$ and is independent of the device spectral response, but at present the calibration facility at SERI is restricted to devices smaller than $3.3 \mathrm{~cm}$ in diameter. The direct-normal uncertainty limit was confirmed by comparison with $A M 0$ reference cells of $\pm 1 \%$ uncertainty. Because the uncertainty limit of the direct-normal method is small, it should be considered as an additional method for calibration of reference devices, along with the global method.

A common argument against using modules as PV reference devices hinges upon the inability of laboratories to measure the spectral response of modules. In fact, at least one group has been able to measure the spectral response of modules using a Spectrolab Large Area Pulsed Solar Simulator with interference filters [32]. Another possiblity is to use the spectral response measured from one cell in a multiple-cell package. This will result in only a small increase in the calibration uncertainty because the spectral correction factor is normally less than $2 \%$.

The PEP '87 package for a reference cell in a single-cell package has no apparent field-of-view, encapsulation, or wiring problems. The large thermal mass of the package and the $2.5 \mathrm{~cm}$ height of the cell above the base can introduce appreciable errors for some measurement systems. This is especially true when this package is used to set the simulator for a cell held down with vacuum to a temperature controlled plate. This is because most solar simulators have. a rather large intensity gradient above the sample plane, as much as $5 \%$ per $\mathrm{cm}$. This problem can be readily corrected by requiring that the fluid cooling assembly be a separate unit that could be attached to a low thermal mass package. This is the philosophy behind the ASTM E 1040 package design. There were no apparent problems with either the reference cells in multiple-cell packages or the modules. The temperature sensors should be of rugged construction and should be attached to the back-side of the PV cells before encapsulation, and several temperature sensors should be used on the modules.

Another requirement of a reference device should be to restrict the slope of the $I-V$ curve near the short-circuit current point to less than $0.05 \%$ per $m V$ because many PV measurement and calibration 
systems cannot actively bias devices to within a few millivolts of $I_{s c}$. The amorphous silicon reference devices used in the intercomparison would not meet this requirement. These devices should be considered modules because they are actually several single-junction cells connected in series.

The $I-V$ performance characteristics of the PEP ' 87 modules were measured with the SPI-SUN solar simulator and measurement system (Appendix B, Table 3-8). The majority of solar simulators for modules are pulsed, requiring that the module $I-V$ characteristic be measured in a short period of time. The high sweep rate $\left(>1000 \mathrm{Vsec}^{-1}\right)$ of these measurement systems can introduce an error because the voltage is not in equilibrium. The \pm 1 to $\pm 3 \%$ spatial nonuniformity and lack of diffuse irradiance in solar simulators can cause problems in measuring the $I-V$ characteristics. This is one of the motivations for using outdoor $I-V$ measurements, but the temperature, total irradiance, and spectral irradiance will not match the reference conditions. Translation equations for the entire $I-V$ curve have been developed, but the needed translation coefficients will probably be sample-specific. 


\subsection{REFERENCES}

1. H. Ossenbrink, K. Krebs, and R. Van Steenwinkel, "The Results of the 1984/1985 Round-Robin Calibration of Reference Cells for the Summit Working Group on Technology, Growth and Employment," Proc. 18th IEEE Photovoltaic Spec. Conf., Las Vegas, NV, October 21-25, 1985, p. 943, New York: IEEE, 1985. Also published as a technical report for the Commission of the European Communities Directorate-General SCIE, Research and Development, Joint Research Center, ISPRA Establishment, I-21020 ISPRA, Number EUR 10613 EN, 1986.

2. R. Abernathy and R. Benedict, "Measurement Uncertainty: A Standard Methodology," ISA Trans., Vol. 24, 1985, pp. 74-79.

3. "Fluid Flow Measurement Uncertainty," ISO Draft Standard ISO / DIS 5168, International Organization for Standardization Committee TC30-SC9, May 1987.

4. "Instruments and Apparatus: Part 1 Measurement Uncertainty," ASME Standard PTC 19.1-1985, New York: American Society for Mechanical Engineers, 1985.

5. Anon. "Pyrheliometric Comparisons, 1985 Results and Symposium", Sixth International Pyrheliometer Comparisons (IPC VI), Work Report \#137, Zurich, Switzerland: Swiss Meteorological Institute, December 1985. Also see C. Frolich, "Radiometry at PMOD and the World Radiometric Reference," Advances in Radiometry, Proc. International Meeting, June 24-25, 1985, edited by P.V. Foukal Cambridge, MA: Atmospheric and Environmental Research, Inc. 1985.

6. D.R. Myers, Uncertainty Analysis for Thermopile Pyranometer and Pyrheliometer Calibrations Performed at SERI, SERI / TR-215-3294, Golden, CO: Solar Energy Research Institute, April 1988.

7 "Calibration of Reference Pyranometers With Axis Vertical by Shading Method," ASTM Standard E 913, Philadelphia, PA: American Society for Testing and Materials, 1982.

8. J.H. Walker, R.D. Sanders, and A.D. Hattenburg, "Spectral Irradiance Calibrations," National Institute of Standards and Technology (formerly NBS), SP250-20, 1987.

9. "Final Report on Pyranometry," Subtask C, Task IX, Int. Energy Agency Solar Heating and Cooling Programme, 1988.

10. D.R. Myers, "Uncertainty Analysis and Quality Control Applications to Radiometric Data," Proc. Council on Optical Radiometric Measurements, Gaithersburg, MD: National Bureau of Standards (now National Institute of Standards and Technology), May 1987.

11. T.W. Cannon "Spectral Solar Irradiance Instrumentation and Measurement Techniques," Solar Cells, Vol. 18, 1986, pp. 233-241. 
12. C.R. Osterwald, K.A. Emery, D.R. Myers, and C.J. Riordan, "Extending the Spectral Range of Silicon Based Direct-Beam Solar Spectral Radiometric Measurements," Proc. 20th IEEE Photovoltaic Spec. Conf., Las Vegas, NV, September 26-30, 1988, New York: IEEE, 1988.

13. T.J. Coutts and C.R. Osterwald, "The Quantum Efficiency of CdS / CuInSe $e_{2}$ and $\operatorname{In}_{2} \mathrm{O}_{3}: \mathrm{Sn} /$ InP Solar Cells," Solar Cells, Vol. 22, 1987, pp. 195-209.

14. K.A. Emery and C.R. Osterwald, "Efficiency Measurements and Other Performance Rating Methods," Current Topics in Photovoltaics, Vol. 3, Chapt. 4, edited by T.J. Coutts, Academic Press, 1988.

15. K.A. Emery and C.R. Osterwald, "Solar Cell Efficiency Measurements," Solar Cells, Vol. 17, 1986, pp. 253-274.

16. C.R. Osterwald, "Translation of Device Performance Measurements to Reference Conditions," Solar Cells, Vol. 18, 1986, pp. 269-273.

17. K. Heidler and J. Beier, "Uncertainty Analysis of PV Measurements with a Solar Simulator: Spectral Mismatch, Non-Uniformity and Other Sources of Error," Proc. 8th European Solar Energy Conf., Florence, Italy, May 9-12, 1988, pp. 549-559.

18. K.A. Emery, C.R. Osterwald, and C.V. Wells, "Uncertainty Analysis of Photovoltaic Efficiency Measurements," Proc. 19th IEEE Photovoltaic Spec. Conf., New Orleans, LA, May 4-8, 1987, pp. 153-159, New York: IEEE, 1987.

19. K.A. Emery, C.R. Osterwald, T.W. Cannon, D.R. Myers, J. Burdick, T. Glatfelter, W. Czubatyj, and J. Yang, "Methods for Measuring Solar Cell Efficiency Independent of Reference Cell or Light Source," Proc. 18th IEEE Photovoltaic Spec. Conf., Las Vegas, NV, October 21-25, 1985 pp. 623-628, New York: IEEE, 1985.

20. "Standard Test Method for Calibration of Primary Non-Concentrator Terrestrial Photovoltaic Reference Cells Using a Tabular Spectrum," ASTM Sandard E 1125, Philadelphia, PA: American Society for Testing and Materials, 1986.

21. "Standard Procedures for Terrestrial Photovoltaic Measurements," Commission of the European Community, CEC 101, Issure 2, EUR 7078 EN, 1981.

22. "Standard for Terrestrial Solar Spectral Irradiance Tables at Air Mass 1.5," ASTM Standard E 892, Philadelphia, PA: American Society for Testing and Materials, 1987.

23. R.E. Bird, R.L. Hulstrom, and L.J. Lewis, "Terrestrial Solar Spectral Data Sets," Solar Energy, Vol. 39, 1983, pp. 563-573.

24. Y. Miyake, R. Shimokawa, Y. Nakanishi, and Y. Hamakawa, "Global Radiation Model and Angular Distribution of the Diffuse Irradiance," Solar Cells, Vol. 20, 1987, pp. 127-143.

25. R. Shimokawa, Y. Miyake, Y. Nakanishi, Y. Kuwano, and Y. Hamakawa, "Possible Errors Due to Deviation in the Reference Cell Calibration Under Global Irradiance," Japan. J. Appl. Phys., Vol. 25, 1986, pp. L102-L104. 
26. R. DeBlasio, D. Waddington, and L. Mrig, "Outdoor Performance and Stability Testing of Thin Film Devices," Solar Cells, Vol. 21, 1987, pp. 343-352.

27. B. Anspaugh, "A Verified Technique for Calibrating Space Solar Cells," Proc. 19th IEEE Photovoltaic Spec. Conf., New Orleans, LA, May 4-8, 1987, pp. 542-547, New York: IEEE, 1987.

28. H.W. Brandhorst, "Calibration of Solar Cells Using High Altitude Aircraft," Proc. of the International Colloquium Organized by ECOSEC, July 6-10, 1974, Toulouse, France, pp. 565-574. Also published as a technical report, NASA TN D-2508, Cleveland, OH: NASA Lewis Research Center, 1975.

29. K.A. Emery, C.R. Osterwald, L.L. Kazmerski, and R.E. Hart, "Calibration of Primary Terrestrial References Cells When Compared with Primary AM0 Reference Cells," Proc. 8th European Photovoltaic Solar Energy Conf., Florence, Italy, May 9-12, 1988, pp. 64-68.

30. "Standard Test Methods for Electrical Performance of Non-Concentrator Terrestrial Photovoltaic Cells using Reference Cells," ASTM Standard E 948, Philadelphia, PA: American Society for Testing and Materials, 1983.

31. R. Walraven, "Calculating the Position of the Sun," Solar Energy, Vol. 20, 1978, pp. 393-397.

32. J.C. Zimmerman, Sun-Pointing Programs and their Accuracy, SAND81-0761, Albuquerque, NM: Sandia National Laboratories, May 1981.

33. M. Iqbal, An Introduction to Solar Radiation, Academic Press, 1983.

34. L. Zafonte, R.G. Downing, R. Mueller, B. Anspaugh, R. Weiss, and R. Webster, Solar Cell Measurement Standardization Devices and Procedures, SERI / STR-213-3063, Golden, CO: Solar Energy Research Institute, November 1986.

35. B.Y.H. Liu and R.C. Jordan, "The Interrelationship and Characteristic Distribution of Direct, Diffuse and Total Solar Radiation," Solar Energy, Vol. 4, 1960, pp. 1-19.

36. E.L. Maxwell, T.L. Stoffel, and R.E. Bird, Measuring and Modeling Solar Irradiance on Vertical Surfaces, SERI/TR-215-2525, Golden, CO: Solar Energy Research Institute, July 1986.

37. "Standard Specification for Physical Characteristics of Non-concentrator Terrestrial Photovoltaic Reference Cells," ASTM Standard E 1040, Philadelphia, PA: American Society for Testing and Materials, 1986. 


\section{APPENDIX A \\ IEC TC82 / WG2 GLOBAL CALIBRATION METHOD AND GLOBAL REFERENCE SPECTRUM}

Table A-1. Primary Reference Device Calibration Methods (Quoted verbatum from IEC TC82 / WG2 document (Secretariat 24), 88, Appendix B)

\section{B. Global Sunlight Method}

B1. Principle

- The calibration value is computed from (a) the relative spectral response of the device, (b) its short-circuit current in global sunlight of measured irradiance and relative spectral irradiance distribution and (c) the reference solar spectral irradiance distribution.

B2. Apparatus

- A class 1 pyranometer, calibrated outdoors against a primary absolute cavity radiometer conforming to the world radiometric reference, under the same environmental conditions as those required for reference device calibration (see B3 below).

- A platform, horizontal or sun facing, on which the pyranometer is mounted coplanar with the reference device (cell or module)

- A removable shade to keep the reference device at or near ambient temperature (not necessary for single reference cells where the junction temperature is effectively controlled to $25^{\circ} \mathrm{C}$ $\pm 1^{\circ} \mathrm{C}$ ).

- Means for measuring the cell temperature in the reference device to an accuracy of $\pm 1{ }^{\circ} \mathrm{C}$.

- Data acquisition system.

- If a sun facing platform is used, means to limit ground reflections (as measured with the pyranometer) to not more than $3 \%$.

- If the spectral correction procedure is carried out, a suitably calibrated spectroradiometer.

B3. Environmental Conditions (Inserted for clarity)

- Clear, sunny weather.

- Irradiance as measured with the pyranometer, not less than $800 \mathrm{Wm}^{-2}$.

- Diffuse / total irradiance ratio not more than 0.25 .

- With horizontal platform, solar elevation not less than $54^{\circ}$.

- With a sun facing platform, air mass between AM1 and AM2 for crystalline silicon reference cells or between AM1 and AM1.5 for amorphous silicon and other thin film cells.

\section{B4. Test Procedure}

1. Before proceeding to the calibration site, measure the temperature coefficient of short-circuit current of the reference device, using the procedure specified in the relevant IEC standard (under consideration). 
2. At the calibration site, set up the apparatus, with the shade in position over the reference device, and check that the environmental conditions are within the specified limits.

3. When all is ready, remove the shade and immediately make simultaneous measurements of reference device short-circuit current $I_{s c}$, cell temperature and irradiance in quick succession, until the ratio:

$I_{s c}$ (corrected to $25^{\circ} \mathrm{C}$ )

Irradiance

$$
\left(\mathrm{AW}^{-1} \mathrm{~m}^{2}\right)
$$

varies by less than $1 \%$ over 5 successive sets of readings. Record these ratios.

4. $\quad$ Repeat steps 2 and 3 on at least 2 other days.

5. Take the mean of the recorded ratios as the uncorrected calibration value $C V_{U}$.

6. Multiply $C V_{U}$ by the appropriate spectral correction factor $k$ to give the corrected calibration value $C V$, i.e. the short-circuit current per unit of irradiance having the reference spectral irradiance distribution :

$C V=k \times C V_{U}$

\section{Determination of $k$}

The spectral correction factor $k$ may be determined as follows:

1. Measure the relative spectral response of the reference device.

2. At the same time as or immediately after each day's calibration measure the relative spectral irradiance distribution of the incident sunlight, using a suitably calibrated spectroradiometer with an integrating sphere or a flat diffuse reflecting surface to direct an integrated sample of the total sunlight on to the entrance slit. The spectroradiometer must cover the spectral response range of the reference device.

3. . For each day, compute the corrected calibration value $C V$ as follows:

$$
C V=C V_{u} \times \frac{\int k_{2} E_{G}(\lambda) d \lambda}{\int E_{R}(\lambda) d \lambda} \times \frac{\int k_{1} s(\lambda) E_{R}(\lambda) d \lambda}{\int k_{1}(\lambda) k_{2} E_{G}(\lambda) d \lambda}
$$

where:

$C V_{U} \quad=$ the uncorrected calibration value at $25^{\circ} \mathrm{C}\left(\mathrm{AW}^{-1} \mathrm{~m}^{2}\right)$

$s(\lambda) \quad=$ absolute spectral response of the reference devices at wavelength $\lambda$

$k_{l} s(\lambda) \quad=$ measured relative spectral response of the reference device at wavelength $\lambda$ 
$E_{R}(\lambda) \quad=$ reference solar spectral irradiance at wavelength $\lambda$

$E_{G}(\lambda) \quad=$ absolute spectral irradiance of the sunlight in which the short-circuit current was measured at wavelength $\lambda$

$k_{2} E_{G}(\lambda) \quad=$ measured relative spectral irradiance of this sunlight

The range of all the integral in the above equation shall correspond to the range of the measured relative spectral solar irradiance.

4. Calculate: $k=$ mean $\frac{C V}{C V_{U}}$

Alternatively, if facilities for spectral irradiance are not available, $k$ may be established from spectrally-corrected calibrations of the reference devices carried out by a competent agency. Round-Robin exercises could be used to this end.

The correction factor $k$ will be found to be very consistent and near unity. Once it has been established for a particular calibration site and type of cell, the above correction procedure need not be repeated. 
Table A-2. IEC TC82 Global Reference Spectral Irradiance Distribution Normalized to Integrate to $1000 \mathrm{Wm}^{-2}$

\begin{tabular}{|c|c|c|c|c|c|c|c|}
\hline $\begin{array}{c}\lambda \\
(\mu \mathrm{m})\end{array}$ & $\begin{array}{c}E_{\lambda} \\
\left.\mathrm{Wm}^{-2} \mu \mathrm{m}^{-1}\right)\end{array}$ & $\begin{array}{c}\lambda \\
(\mu \mathrm{m})\end{array}$ & $\begin{array}{c}E_{\lambda} \\
\left(\mathrm{Wm}^{-2} \mu \mathrm{m}^{-1}\right)\end{array}$ & $\begin{array}{c}\lambda \\
(\mu \mathrm{m})\end{array}$ & $\begin{array}{c}E_{\lambda} \\
\left(W \mathrm{~m}^{-2} \mu \mathrm{m}^{-1}\right)\end{array}$ & $\begin{array}{c}\lambda \\
(\mu \mathrm{m})\end{array}$ & $\begin{array}{c}E_{\lambda} \\
\left(W^{-2} \mu m^{-1}\right)\end{array}$ \\
\hline 0.305 & 9.5 & 0.590 & 1395.5 & 0.9935 & 746.8 & 1.860 & 2.0 \\
\hline 0.310 & 42.3 & 0.610 & 1485.3 & 1.040 & 690.5 & 1.920 & 1.2 \\
\hline 0.315 & 107.8 & 0.630 & 1434.1 & 1.070 & 637.5 & 1.960 & 21.2 \\
\hline 0.320 & 181.0 & 0.650 & 1419.9 & 1.100 & 412.6 & 1.985 & 91.1 \\
\hline 0.325 & 246.8 & 0.670 & 1392.3 & 1.120 & 108.9 & 2.005 & 26.8 \\
\hline 0.330 & 395.3 & 0.690 & 1130.0 & 1.130 & 189.1 & 2.035 & 99.5 \\
\hline 0.340 & 435.3 & 0.710 & 1316.7 & 1.137 & 132.2 & 2.065 & 60.4 \\
\hline 0.345 & 438.9 & 0.718 & 1010.3 & 1.161 & 339.0 & 2.100 & 89.1 \\
\hline 0.350 & 483.7 & 0.7244 & 1043.2 & 1.180 & 460.0 & 2.148 & 82.2 \\
\hline 0.360 & 520.3 & 0.740 & 1211.2 & 1.200 & 423.6 & 2.198 & 71.5 \\
\hline 0.370 & 666.2 & 0.7525 & 1193.9 & 1.235 & 480.5 & 2.270 & 70.2 \\
\hline 0.380 & .712 .5 & 0.7575 & 1175.5 & 1.290 & 413.1 & 2.360 & 62.0 \\
\hline 0.390 & 720.7 & 0.7625 & 643.1 & 1.320 & 250.2 & 2.450 & 21.2 \\
\hline 0.400 & 1013.1 & 0.7675 & 1030.7 & 1.350 & 32.5 & 2.494 & 18.5 \\
\hline 0.410 & 1158.2 & 0.780 & 1131.1 & 1.395 & 1.6 & 2.537 & 3.2 \\
\hline 0.420 & 1184.0 & 0.800 & 1081.6 & 1.4425 & 55.7 & 2.941 & 4.4 \\
\hline 0.430 & 1071.9 & 0.816 & 849.2 & 1.4625 & 105.1 & 2.973 & 7.6 \\
\hline 0.440 & 1302.0 & .0 .8237 & 785.0 & 1.477 & 105.5 & 3.005 & 6.5 \\
\hline 0.450 & 1526.0 & 0.8315 & 916.4 & 1.497 & 182.1 & 3.056 & 3.2 \\
\hline 0.460 & 1599.6 & 0.840 & 959.9 & 1.520 & 262.6 & 3.132 & 5.4 \\
\hline 0.470 & 1581.0 & 0.860 & 978.9 & 1.539 & 274.2 & 3.156 & 19.4 \\
\hline 0.480 & 1628.3. & 0.880 & 933.2 & 1.558 & 275.0 & 3.204 & 1.3 \\
\hline 0.490 & 1539.2 & 0.905 & 748.5 & 1.578 & 244.6 & 3.245 & 3.2 \\
\hline 0.500 & 1548.7 & 0.915 & 667.5 & 1.592 & 247.4 & 3.317 & 13.1 \\
\hline 0.510 & 1586.5 & 0.925 & 690.3 & 1.610 & 228.7 & 3.344 & 3.2 \\
\hline 0.520 & 1484.9 & 0.930 & 403.6 & 1.630 & 244.5 & 3.450 & 13.3 \\
\hline 0.530 & 1572.4 & 0.937 & 258.3 & 1.646 & 234.8 & 3.573 & 11.9 \\
\hline 0.540 & 1550.7 & 0.948 & 313.6 & 1.678 & 220.5 & 3.765 & 9.8 \\
\hline 0.550 & 1561.5 & 0.965 & 526.8 & 1.740 & 171.5 & 4.045 & 7.5 \\
\hline 0.570 & 1501.5 & 0.980 & 646.4 & 1.800 & 30.7 & & \\
\hline
\end{tabular}




\section{APPENDIX B \\ DATA SHEETS FOR THE PEP 1987 SUMMIT ROUND ROBIN}

This appendix contains the data sheets in the format requested by the organizing agent for the PEP ' 87 Summit Round-Robin. Section 3 of this report discusses the various PV calibration methods employed in this study, while the data sheets contain the calibration values obtained using the Kipp \& Zonen pyranometer to measure the total irradiance. The data sheets contain the calibration values using the global-normal method for the reference cells in single-cell packages, and the global fixed-tilt method for modules and reference cells in multiple-cell packages. The $I-V$ data for reference cells in single- and multiple-cell packages in Tables B-2 to B-8 were obtained using the SERI Spectrolab X-25 solar simulator, and the $I-V$ data for reference modules in Tables B-3 to B-8 were obtained using the Spire SPI-SUN Model 240 measurement system. 
Table B-1.

Test Data Sheet for Pyranometer

Date: November 29, 1988

Organization:

Solar Energy Research Institute

1617 Cole Blvd.

Country:

Golden, CO 80401

USA

DATA

(1) Calibration value of the round-robin pyranometer CM11 (Kipp \& Zonen):

$205.0 \mathrm{Wm}^{-2} \mathrm{mV}^{-1}$ (calibrated on a horizontal surface)

(2) - Average temperature of air:

" $"$ of pyranometer body: $20.2^{\circ} \mathrm{C}$ (range $5-22^{\circ} \mathrm{C}$ )

(3) Sketch of the mounting manner on page 4 .

Specification of the reference detector/radiometer used for calibration:

Type: $\quad$ TMI Mk-VI absolute cavity radiometer

Serial No.: $\quad 68018$

Manufacturer:

Date of Calibration:

Technical Measurements Inc.

Traceable to the World Radiometric Reference through comparisons with SERI reference absolute cavity radiometer TMI 67814, the NOAA reference absolute cavity radiometer TMI 67502, and other absolute cavity radiometers from 1980 through September 1987.

Calibration Value:

Multiplicative constant $0.99814 \pm 0.0012$ adjusts radiometer to WRR.

Accuracy:

The PEP ' 87 pyranometer was calibrated using the method described in Section 2.3 and has an estimated $U_{95}$ uncertainty of $\pm 3.8 \%$. Figure 2-2 shows the calibration value $v s$. zenith angle.

The cavity radiometer used to measure the direct component (TMI 68018) has an estimated $U_{95}$ uncertainty of $\pm 0.3 \%$, and the Eppley PSP (17802F3) used for the diffuse component has an estimated $U_{95}$ uncertainty of $\pm 2.8 \%$.

Responsible person

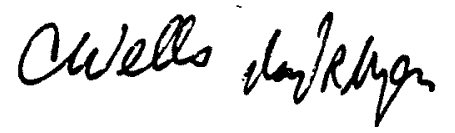


Table B-2.

Test Data Sheet for Reference Devices

Date: December 20, 1988

Organization:

Country:

Solar Energy Research Institute

1617 Cole Blvd.

Golden, CO 80401

USA

(1) Primary calibration (data at STC)

\begin{tabular}{|c|c|c|c|c|c|c|c|c|}
\hline \multicolumn{4}{|c|}{$\begin{array}{l}\text { Reference Cell in Single-Cell Package } \\
\qquad\left(\mathrm{T}=\mathbf{2 5 ^ { \circ } \mathrm { C } ) \dagger \dagger}\right.\end{array}$} & \multicolumn{5}{|c|}{$\begin{array}{c}\text { Reference Cell in Multi-Cell Package } \\
\text { primary calibration } \dagger\end{array}$} \\
\hline I.D. & $I_{s c}(\mathbf{A})$ & $V_{o c}(V)$ & FF & I.D. & $I_{s c}(A)$ & $V_{o c}(V)$ & FF & $\mathbf{T}\left({ }^{\circ} \mathbf{C}\right) \dagger \dagger$ \\
\hline RC -01 & 0.02527 & 1.715 & 0.547 & RM-01 & 0.09127 & 12.74 & 0.677 & 25 \\
\hline RC -02 & 0.02494 & 1.669 & 0.492 & RM-02 & 0.09779 & 12.84 & 0.603 & 25 \\
\hline RC -03 & 0.11112 & 0.587 & 0.788 & RM-03 & 2.8093 & 0.592 & 0.720 & 25 \\
\hline RC-04 & 0.11196 & 0.587 & 0.764 & RM-04 & 2.8299 & 0.584 & 0.729 & 25 \\
\hline RC -05 & 0.09706 & 0.546 & 0.752 & RM-05 & 2.4654 & 0.553 & 0.720 & 25 \\
\hline RC -06 & 0.09650 & 0.547 & 0.745 & RM-06 & 2.4699 & 0.556 & 0.724 & 25 \\
\hline RC-07 & 0.11648 & & & & & & & \\
\hline RC-08 & 0.03315 & 0.561 & 0.745 & & & & & \\
\hline
\end{tabular}

(2) Accuracy (in \%): $\mathbf{I}_{\mathrm{sc}}: \pm 3.8 ; \mathbf{V}_{\mathrm{oc}}: \pm 0.4 ; \mathrm{FF}: \pm 0.5$. (Estimated $U_{95}$ uncertainty limits are for Spectrolab X-25 simulator measurement using a $\pm 3.7 \%$ global-normal calibrated reference cell.

(3) The data of spectral responsivity are shown on pages 28 and 34 .

(4) The calibration method used: Global fixed-tilt for cells in multiple-cell packages, and global-normal for cells in single-cell packages.

(5) The short-circuit current values in the table above are an average of 104 multiple readings, taken on three different days. The spectral irradiance was measured for each data point, and each data point was corrected for temperature and spectrum. Section 3 discusses in detail the calibration procedures and data, and the actual uncorrected spectral irradiance, meteorological, and PV data are available upon request. The ratio of diffuse-to-direct irradiance was less than 0.09 for all of the data points, while the plane-of-measurement total irradiance varied from 800 to $1134 \mathrm{Wm}^{-2}$. The air mass ranged from 1.99 to 3.34 uncorrected and from 1.59 to 2.62 with pressure correction. The solar elevation varied from $17.4^{\circ}$ to $30.0^{\circ}$.

$\dagger$ The RM-series was calibrated outdoors using the global fixed-tilt method and measured indoors with the Spectrolab X-25 simulator system with the device as its own reference cell.

†† Temperature coefficients were measured at SERI (see Table 3-3) and the data were corrected to $25^{\circ} \mathrm{C}$ using the attached Type-J thermocouple. Because $\mathrm{RM}-03$ and $\mathrm{RM}-04$ had broken thermocouples, platinum RTDs were attached to the rear and used to measure temperature.

Responsible person 
Table B-3.

Test Data Sheet for Solar Module SM-01

Date: December 20, 1988

Organization:

Solar Energy Research Institute

1617 Cole Blvd.

Golden, CO 80401

Country:

USA

DATA

Radiation Source:

Spectrolab X-25 for RC- and RM- devices

Spire SPI-SUN Model 240 for SM- devices

The spectral irradiance distribution is shown on page 22 and 23 .

The nonuniformity with the sample module/reference device layout is shown as a graphic on page (not available, $\pm 3 \%$ specified by manufacturer).

Data:

\begin{tabular}{|c|c|c|c|c|c|}
\hline \multicolumn{3}{|c|}{ Data of Reference Cell RC-01 } & \multicolumn{3}{|c|}{ Data of Sample Module SM-01 } \\
\hline $\begin{array}{l}I_{\text {sc }}: \\
V_{o c}: \\
P_{\max }: \\
I_{\max }: \\
V_{\max }: \\
F F: \\
\text { Temp: }\end{array}$ & $\begin{array}{l}0.02527 \\
1.715 \\
0.0237 \\
0.01943 \\
1.220 \\
0.547 \\
25.0\end{array}$ & $\begin{array}{l}(\mathbf{A}) \\
(\mathbf{V}) \\
(\mathbf{W}) \\
(\mathbf{A}) \\
(\mathrm{V}) \\
\left({ }^{\circ} \mathrm{C}\right)\end{array}$ & $\begin{array}{l}I_{s c}: \\
V_{o c}: \\
P_{\text {max }}: \\
I_{\text {max }}: \\
V_{\text {max }}: \\
\text { FF: } \\
\text { Temp: }\end{array}$ & $\begin{array}{c}0.495 \\
38.932 \\
10.37 \\
0.380 \\
27.30 \\
0.538 \\
25.0\end{array}$ & $\begin{array}{l}(\mathbf{A}) \\
(\mathbf{V}) \\
(\mathbf{W}) \\
(\mathbf{A}) \\
(\mathbf{V})\end{array}$ \\
\hline & & & & & \\
\hline \multicolumn{3}{|c|}{ Data of Reference Cell RM-01 } & \multicolumn{3}{|c|}{ Data of Sample Module SM-01 } \\
\hline $\begin{array}{l}I_{\text {sc }}: \\
\mathbf{V}_{o c}: \\
\mathbf{P}_{\max }: \\
I_{\max }: \\
V_{\max }: \\
\text { FF: } \\
\text { Temp: }\end{array}$ & $\begin{array}{l}0.09779 \\
12.84 \\
0.7570 \\
0.08186 \\
9.247 \\
0.603 \\
25.0\end{array}$ & $\begin{array}{l}\text { (A) } \\
(\mathrm{V}) \\
(\mathrm{W}) \\
(\mathrm{A}) \\
(\mathrm{V}) \\
\\
\left({ }^{\circ} \mathrm{C}\right)\end{array}$ & $\begin{array}{l}I_{s c:}: \\
V_{o c}: \\
P_{\text {max }}: \\
I_{\text {max }}: \\
\mathbf{V}_{\text {max }}: \\
\text { FF: } \\
\text { Temp: }\end{array}$ & $\begin{array}{c}0.492 \\
39.036 \\
10.06 \\
0.372 \\
27.05 \\
0.524 \\
25.0\end{array}$ & $\begin{array}{l}(\mathbf{A}) \\
(\mathbf{V}) \\
(\mathbf{W}) \\
(\mathbf{A}) \\
(\mathbf{V}) \\
\left({ }^{\circ} \mathbf{C}\right) \dagger\end{array}$ \\
\hline
\end{tabular}

$\dagger$ No thermocouple was attached; RTD (mounted to rear) measured module temperature.

Responsible person 
Table B-4.

Test Data Sheet for Solar Module SM-02

Date: December 20, 1988

Organization:

Solar Energy Research Institute

1617 Cole Blvd.

Golden, CO 80401

Country:

USA

\section{Radiation Source:}

Spectrolab X-25 for RC- and RM- devices

Spire SPI-SUN Model 240 for SM- devices

The spectral irradiance distribution is shown on page 22 and 23 .

The nonuniformity with the sample module/reference device layout is shown as a graphic on page (not available, $\pm 3 \%$ specified by manufacturer).

\section{Data:}

\begin{tabular}{|c|c|c|c|c|c|}
\hline \multicolumn{3}{|c|}{ Data of Reference Cell RC-02 } & \multicolumn{3}{|c|}{ Data of Sample Module SM-02 } \\
\hline $\begin{array}{l}I_{s c}: \\
V_{o c}: \\
P_{\text {max }}: \\
I_{\text {max }}: \\
V_{\text {max }}: \\
F F: \\
\text { Temp: }\end{array}$ & $\begin{array}{l}0.02494 \\
1.669 \\
0.2051 \\
0.01797 \\
1.140 \\
0.492 \\
25.0\end{array}$ & $\begin{array}{l}(\mathbf{A}) \\
(\mathbf{V}) \\
(\mathbf{W}) \\
(\mathbf{A}) \\
(\mathrm{V}) \\
\left({ }^{\circ} \mathrm{C}\right)\end{array}$ & $\begin{array}{l}I_{s c}: \\
V_{o c}: \\
P_{\max }: \\
I_{\max }: \\
V_{\max }: \\
F F: \\
\text { Temp: }\end{array}$ & $\begin{array}{c}0.4988 \\
39.108 \\
10.24 \\
0.376 \\
27.25 \\
0.525 \\
25.0\end{array}$ & $\begin{array}{l}(\mathbf{A}) \\
(\mathbf{V}) \\
(\mathbf{W}) \\
(\mathbf{A}) \\
(\mathbf{V})\end{array}$ \\
\hline \multicolumn{3}{|c|}{ Data of Reference Cell RM-02 } & \multicolumn{3}{|c|}{ Data of Sample Module SM-02 } \\
\hline $\begin{array}{l}I_{s c}: \\
V_{\alpha c}: \\
P_{\max }: \\
I_{\max }: \\
V_{\max }: \\
\text { FF: } \\
\text { Temp: }\end{array}$ & $\begin{array}{l}0.09127 \\
12.74 \\
0.7875 \\
0.07859 \\
10.02 \\
0.677 \\
25.0\end{array}$ & $\begin{array}{l}(\mathbf{A}) \\
(\mathbf{V}) \\
(\mathbf{W}) \\
(\mathbf{A}) \\
(\mathbf{V})\end{array}$ & $\begin{array}{l}I_{s c}: \\
V_{\alpha c}: \\
P_{\max }: \\
I_{\max }: \\
V_{\max }: \\
\text { FF: } \\
\text { Temp: }\end{array}$ & $\begin{array}{c}0.486 \\
39.995 \\
10.16 \\
0.373 \\
27.25 \\
0.536 \\
25.0\end{array}$ & $\begin{array}{l}(\mathbf{A}) \\
(\mathbf{V}) \\
(\mathbf{W}) \\
(\mathbf{A}) \\
(\mathrm{V})\end{array}$ \\
\hline
\end{tabular}

$\dagger$ No thermocouple was attached; RTD (mounted to rear) measured module temperature.

Responsible person 
Table B-5.

Test Data Sheet for Solar Module SM-03

Date: December 20, 1988

Organization:

Solar Energy Research Institute

1617 Cole Blvd.

Golden, CO 80401

Country:

USA

Radiation Source:

Spectrolab X-25 for RC - and RM- devices

Spire SPI-SUN Model 240 for SM- devices

The spectral irradiance distribution is shown on page 22 and 23 .

The nonuniformity with the sample module/reference device layout is shown as a graphic on page (not available, $\pm 3 \%$ specified by manufacturer).

Data:

\begin{tabular}{|c|c|c|c|c|c|}
\hline \multicolumn{3}{|c|}{ Data of Reference Cell RC $-\mathbf{0 3}$} & \multicolumn{3}{|c|}{ Data of Sample Module SM-03 } \\
\hline $\begin{array}{l}I_{s c}: \\
V_{o c}: \\
P_{\max }: \\
I_{\max }: \\
V_{\max }: \\
\text { FF: } \\
\text { Temp: }\end{array}$ & $\begin{array}{l}0.11112 \\
0.587 \\
0.05100 \\
0.1058 \\
0.4855 \\
0.788 \\
25.0\end{array}$ & $\begin{array}{l}(\mathbf{A}) \\
(\mathrm{V}) \\
(\mathrm{W}) \\
(\mathrm{A}) \\
(\mathrm{V}) \\
\left({ }^{\circ} \mathrm{C}\right)\end{array}$ & $\begin{array}{l}I_{s c}: \\
V_{o c}: \\
P_{\text {max }}: \\
I_{\text {max }}: \\
V_{\text {max }}: \\
F_{F}: \\
\text { Temp: }\end{array}$ & $\begin{array}{c}2.836 \\
21.05 \\
46.07 \\
2.621 \\
17.58 \\
0.772 \\
25.0\end{array}$ & $\begin{array}{l}(\mathbf{A}) \\
(\mathbf{V}) \\
(\mathbf{W}) \\
(\mathbf{A}) \\
(\mathbf{V})\end{array}$ \\
\hline & & & & & \\
\hline \multicolumn{3}{|c|}{ Data of Reference Cell RM-03 } & \multicolumn{3}{|c|}{ Data of Sample Module SM-03 } \\
\hline $\begin{array}{l}I_{s c}: \\
V_{o c}: \\
P_{\max }: \\
I_{\max }: \\
V_{\max }: \\
F F: \\
\text { Temp: }\end{array}$ & $\begin{array}{l}2.8093 \\
0.588 \\
1.189 \\
2.558 \\
0.4648 \\
0.720 \\
25.0\end{array}$ & $\begin{array}{l}(\mathbf{A}) \\
(\mathbf{V}) \\
(\mathbf{W}) \\
(\mathbf{A}) \\
(\mathbf{V})\end{array}$ & $\begin{array}{l}I_{s c}: \\
V_{o c}: \\
P_{\max }: \\
I_{\max }: \\
V_{\max }: \\
F_{\text {F }:}: \\
\text { Temp: }\end{array}$ & $\begin{array}{c}2.781 \\
21.14 \\
45.51 \\
2.633 \\
17.29 \\
0.774 \\
25.0\end{array}$ & $\begin{array}{l}\text { (A) } \\
\text { (V) } \\
\text { (W) } \\
\text { (A) } \\
\text { (V) }\end{array}$ \\
\hline
\end{tabular}

$\dagger$ No thermocouple was attached; RTD (mounted to rear) measured module temperature. 
Table B-6.

Test Data Sheet for Solar Module SM-04

Date: December 20, 1988

Organization:

Solar Energy Research Institute

1617 Cole Blvd.

Golden, CO 80401

Country:

USA

DATA

Radiation Source:

Spectrolab X-25 for RC - and RM- devices

Spire SPI-SUN Model 240 for SM- devices

The spectral irradiance distribution is shown on page 22 and 23 .

The nonuniformity with the sample module/reference device layout is shown

as a graphic on page (not available, $\pm 3 \%$ specified by manufacturer).

Data:

\begin{tabular}{|c|c|c|c|c|c|}
\hline \multicolumn{3}{|c|}{ Data of Reference Cell RC-04 } & \multicolumn{3}{|c|}{ Data of Sample Module SM-04 } \\
\hline $\begin{array}{l}I_{s c}: \\
V_{o c}: \\
P_{\max }: \\
I_{\max }: \\
V_{\max }: \\
\text { FF: } \\
\text { Temp: }\end{array}$ & $\begin{array}{l}0.11196 \\
0.587 \\
0.0502 \\
0.1039 \\
0.483 \\
0.764 \\
25.0\end{array}$ & $\begin{array}{l}(\mathbf{A}) \\
(\mathbf{V}) \\
(\mathbf{W}) \\
(\mathbf{A}) \\
(\mathbf{V}) \\
\left({ }^{\circ} \mathbf{C}\right)\end{array}$ & $\begin{array}{l}I_{\text {sc: }}: \\
V_{o c}: \\
P_{\max }: \\
I_{\max }^{:}: \\
V_{\max }: \\
\text { FF: } \\
\text { Temp: }\end{array}$ & $\begin{array}{c}2.855 \\
21.149 \\
46.29 \\
2.648 \\
17.48 \\
0.767 \\
25.0\end{array}$ & $\begin{array}{l}(\mathbf{A}) \\
(\mathbf{V}) \\
(\mathbf{W}) \\
(\mathbf{A}) \\
(\mathbf{V})\end{array}$ \\
\hline \multicolumn{3}{|c|}{ Data of Reference Cell RM-04 } & \multicolumn{3}{|c|}{ Data of Sample Module SM-04 } \\
\hline $\begin{array}{l}I_{\text {sc: }}: \\
V_{o c}: \\
P_{\max }: \\
I_{\max }: \\
V_{\max }: \\
\text { FF: } \\
\text { Temp: }\end{array}$ & $\begin{array}{l}2.8299 \\
0.594 \\
1.220 \\
2.648 \\
0.461 \\
0.726 \\
25.0\end{array}$ & $\begin{array}{l}(\mathbf{A}) \\
(\mathbf{V}) \\
(\mathbf{W}) \\
(\mathbf{A}) \\
(\mathrm{V}) \\
\left({ }^{\circ} \mathrm{C}\right)\end{array}$ & $\begin{array}{l}I_{s c}: \\
V_{o c}: \\
P_{\max }: \\
I_{\max }: \\
V_{\max }: \\
\text { FF: } \\
\text { Temp: }\end{array}$ & $\begin{array}{c}2.805 \\
21.205 \\
45.74 \\
2.602 \\
17.58 \\
0.769 \\
25.0\end{array}$ & $\begin{array}{l}(\mathbf{A}) \\
(\mathbf{V}) \\
(\mathbf{W}) \\
(\mathbf{A}) \\
(\mathbf{V})\end{array}$ \\
\hline
\end{tabular}

$\uparrow$ No thermocouple was attached; RTD (mounted to rear) measured module temperature.

Responsible person 
Table B-7.

Test Data Sheet for Solar Module SM-05

Date: December 20, 1988

Organization:

Solar Energy Research Institute

1617 Cole Blvd.

Golden, CO 80401

Country:

USA

DATA

Radiation Source:

Spectrolab X-25 for RC- and RM- devices

Spire SPI-SUN Model 240 for SM- devices

The spectral irradiance distribution is shown on page 22 and 23 .

The nonuniformity with the sample module/reference device layout is shown as a graphic on page (not available, $\pm 3 \%$ specified by manufacturer).

\section{Data:}

\begin{tabular}{|c|c|c|c|c|c|}
\hline \multicolumn{3}{|c|}{ Data of Reference Cell RC- 05} & \multicolumn{3}{|c|}{ Data of Sample Module SM-05 } \\
\hline $\begin{array}{l}\mathbb{I}_{s c}: \\
V_{o c}: \\
P_{\max }: \\
\mathbb{I}_{\max }: \\
V_{\max }: \\
\text { FF: } \\
\text { Temp: }\end{array}$ & $\begin{array}{l}0.09706 \\
0.546 \\
0.3984 \\
0.00889 \\
0.488 \\
0.752 \\
25.0\end{array}$ & $\begin{array}{l}(\mathbf{A}) \\
(\mathbf{V}) \\
(\mathbf{W}) \\
(\mathrm{A}) \\
(\mathrm{V}) \\
\left({ }^{\circ} \mathrm{C}\right)\end{array}$ & $\begin{array}{l}I_{s c}: \\
V_{\alpha c}: \\
P_{\max }: \\
I_{\max }: \\
V_{\max }: \\
F_{\text {max }}: \\
\text { Temp: }\end{array}$ & $\begin{array}{c}2.543 \\
10.903 \\
20.07 \\
2.309 \\
8.69 \\
0.724 \\
25.0\end{array}$ & $\begin{array}{l}\text { (A) } \\
(\mathrm{V}) \\
(\mathrm{W}) \\
(\mathrm{A}) \\
(\mathrm{V}) \\
\left({ }^{\circ} \mathrm{C}\right) \dagger\end{array}$ \\
\hline \\
\hline \multicolumn{3}{|c|}{ Data of Reference Cell RM-05 } & \multicolumn{3}{|c|}{ Data of Sample Module SM -05} \\
\hline $\begin{array}{l}I_{s c}: \\
V_{o c}: \\
P_{\max }: \\
I_{\max }: \\
V_{\max }: \\
F F^{\prime}: \\
\text { Temp: }\end{array}$ & $\begin{array}{l}2.4654 \\
0.553 \\
0.983 \\
2.286 \\
0.430 \\
0.677 \\
25.0\end{array}$ & $\begin{array}{l}(\mathbf{A}) \\
(\mathbf{V}) \\
(\mathbf{W}) \\
(\mathbf{A}) \\
(\mathbf{V})\end{array}$ & $\begin{array}{l}I_{s c i}: \\
V_{\alpha c}: \\
P_{\max }: \\
I_{\max }: \\
V_{\max }: \\
F F: \\
\text { Temp: }\end{array}$ & $\begin{array}{c}2.559 \\
10.850 \\
19.96 \\
2.336 \\
8.55 \\
0.719 \\
25.0\end{array}$ & $\begin{array}{l}\text { (A) } \\
(\mathbf{V}) \\
(\mathbf{W}) \\
(\mathbf{A}) \\
(\mathbf{V})\end{array}$ \\
\hline
\end{tabular}

$\dagger$ No thermocouple was attached; RTD (mounted to rear) measured module temperature.

Responsible person 
Table B-8.

Test Data Sheet for Solar Module SM-06

Date: December 20, 1988

Organization:

Solar Energy Research Institute

1617 Cole Blvd.

Golden, CO 80401

Country:

USA

-DATA

Radiation Source:

Spectrolab X-25 for RC- and RM- devices .

Spire SPI-SUN Model 240 for SM- devices

The spectral irradiance distribution is shown on page 22 and 23.

The nonuniformity with the sample module/reference device layout is shown as a graphic on page (not available, $\pm 3 \%$ specified by manufacturer).

\section{Data:}

\begin{tabular}{|c|c|c|c|c|c|}
\hline \multicolumn{3}{|c|}{ Data of Reference Cell RC-06 } & \multicolumn{3}{|c|}{ Data of Sample Module SM-06 } \\
\hline $\begin{array}{l}I_{\text {sc }}: \\
V_{o c}: \\
P_{\text {max }}: \\
I_{\max }: \\
V_{\max }: \\
\text { FF: } \\
\text { Temp: }\end{array}$ & $\begin{array}{l}0.09650 \\
0.547 \\
0.0393 \\
0.08997 \\
0.437 \\
0.745 \\
25.0\end{array}$ & $\begin{array}{l}(\mathbf{A}) \\
(\mathbf{V}) \\
(\mathbf{W}) \\
(\mathbf{A}) \\
(\mathbf{V})\end{array}$ & $\begin{array}{l}I_{\text {sc }}: \\
\mathbf{V}_{o c}: \\
P_{\text {max }}: \\
I_{\max }: \\
V_{\max }: \\
\text { FF: } \\
\text { Temn: }\end{array}$ & $\begin{array}{c}2.531 \\
10.720 \\
19.44 \\
2.301 \\
8.45 \\
0.716\end{array}$ & $\begin{array}{l}(\mathbf{A}) \\
(\mathbf{V}) \\
(\mathbf{W}) \\
(\mathbf{A}) \\
(\mathbf{V})\end{array}$ \\
\hline \multicolumn{3}{|c|}{ Data of Reference Cell RM-06 } & \multicolumn{3}{|c|}{ Data of Sample Module SM-06 } \\
\hline $\begin{array}{l}I_{\text {sc }}: \\
V_{o c}: \\
P_{\text {max }}: \\
I_{\max }: \\
V_{\max }: \\
\text { FF: } \\
\text { Temp: }\end{array}$ & $\begin{array}{l}2.4699 \\
0.552 \\
0.991 \\
2.254 \\
0.440 \\
0.727 \\
25.0\end{array}$ & $\begin{array}{l}(\mathbf{A}) \\
(\mathbf{V}) \\
(\mathbf{W}) \\
(\mathbf{A}) \\
(\mathbf{V})\end{array}$ & $\begin{array}{l}I_{\text {sc }}: \\
V_{o c}: \\
P_{\text {max }}: \\
I_{\max }: \\
V_{\max }: \\
\text { FF: } \\
\text { Temp: }\end{array}$ & $\begin{array}{c}2.570 \\
10.685 \\
19.55 \\
2.328 \\
8.40 \\
0.712 \\
25.0\end{array}$ & $\begin{array}{l}(\mathbf{A}) \\
(\mathbf{V}) \\
(\mathbf{W}) \\
(\mathbf{A}) \\
(\mathbf{V})\end{array}$ \\
\hline
\end{tabular}

$\dagger$ No thermocouple was attached; RTD (mounted to rear) measured module temperature.

Responsible person 


\section{APPENDIX C \\ UNCORRECTED DATA FOR GLOBAL FIXED-TILT AND SPIRE SPI-SUN 240 SIMULATOR MEASUREMENTS}

The data in Tables $\mathrm{C}-1$ to $\mathrm{C}-12$ were measured at the SERI Advanced PV Module Test Facility (Figures 2-12 and 2-13, and Figure 2-19, the Spire SPI-SUN simulator). The global fixed-tilt measurement system is described in Reference 14. The global fixed-tilt calibration procedures used in this study and the estimated uncertainty are summarized in Section 2.6.1. The Spire SPI-SUN measurement system along with an estimate of the uncertainty is described in Section 2.6.3.

The Spire simulator baseline data in Tables $\mathrm{C}-1$ to $\mathrm{C}-12$ represent measurements using a SERI secondary reference cell calibrated using the simulator method (Spectrolab X-25, direct-normal primary reference cell). The single-crystal silicon referénce cell S12 was used for the single- and poly-crystalline silicon PEP '87 modules and reference cells in multiple-cell packages. The filtered-silicon (Schott KG5) reference cell S12 was used for the amorphous silicon samples. The term "RTD (C) SERI" refers to the sample temperature in ${ }^{\circ} \mathrm{C}$ measured with a platinum RTD pasted to the back side of the sample. The term "THERM (C)" refers to the module or reference cell in a multiple-cell package sample temperature measured with the attached thermocouple. If no thermocouple was attached, then "NO TC" is indicated. For samples in which the thermocouple was open-circuited, "OPEN" is indicated.

The outdoor baseline measurements shown in Tables $\mathrm{C}-1$ to $\mathrm{C}-12$ were measured using an Eppley pyranometer (Figure 2-6). The term "INSOL." refers to the total irradiance in $\mathrm{Wm}^{-2}$. Except for the baseline case, the outdoor insolation data were measured with the PEP '87 Kipp \& Zonen CM11-4 pyranometer. The term "DIRECT" refers to direct normal irradiance measured with a primary absolute cavity radiometer. The term "DIFFUSE" refers to the plane-of-measurement diffuse irradiance as measured with a shaded pyranometer (Figure 2-7). "TIME" indicates the Mountain Standard Time of the test. 
Table C-1. Global Fixed-Tilt and SPI-SUN 240 Data for Sample RM-01

SERI PV MEASUREMENTS AND PERFORMANCE BRANCH TEST REPORT \# 8917

TEST ITEM RM-01 (a-Si)

SPIRE SIMULATOR

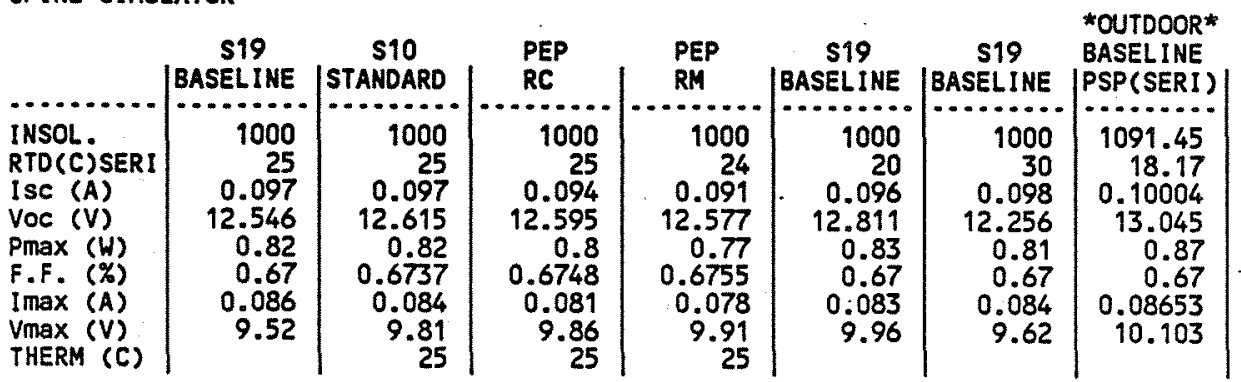

OUTDOOR DAY 1 (DEC. 1 , 1988) PEP K\&Z PYRANOMETER

\begin{tabular}{|c|c|c|c|c|c|c|}
\hline RUN & 1 & 2 & 3 & 4 & 5 & 6 \\
\hline $\begin{array}{l}\text { TIME } \\
\text { INSOL. } \\
\text { RTD (C)SERI } \\
\text { ISC (A) } \\
\text { VOC (V) } \\
\text { Pmax (W) } \\
\text { F.F. (\%) } \\
\text { Inax (A) } \\
\text { Vmax (V) } \\
\text { THERM (C) } \\
\text { DIRECT } \\
\text { DIFUSE }\end{array}$ & $\begin{array}{r}13: 58: 25 \\
865.1 \\
25.39 \\
0.07681 \\
12.683 \\
0.66 \\
0.679 \\
0.06591 \\
10.042 \\
24.9 \\
922.6 \\
63.06\end{array}$ & $\begin{array}{r}13.59 .54 \\
858.33 \\
27.78 \\
0.07655 \\
12.57 \\
0.65 \\
0.679 \\
0.06573 \\
9.943 \\
27.6 \\
922.5 \\
63.14\end{array}$ & $\begin{array}{r}14: 01: 18 \\
855.88 \\
29.73 \\
0.07625 \\
12.476 \\
0.65 \\
0.68 \\
0.06558 \\
9.868 \\
29.7 \\
922 \\
63.31\end{array}$ & $\begin{array}{r}14: 02: 53 \\
848.09 \\
31.73 \\
0.07565 \\
12.376 \\
0.64 \\
0.681 \\
0.06507 \\
9.793 \\
31.8 \\
917.6 \\
62.55\end{array}$ & $\begin{array}{r}14: 04: 18 \\
841.93 \\
33.51 \\
0.07527 \\
12.292 \\
0.63 \\
0.681 \\
0.0648 \\
9.718 \\
33.7 \\
915.9 \\
61.79\end{array}$ & $\begin{array}{r}14: 17.53 \\
788.84 \\
31.69 \\
0.07465 \\
12.345 \\
0.57 \\
0.617 \\
0.06306 \\
9.016 \\
32.1 \\
889.8 \\
58.65\end{array}$ \\
\hline
\end{tabular}

OUTDOOR DAY 2 (DEC. 2, 1988) PEP K\&Z PYRANOMETER

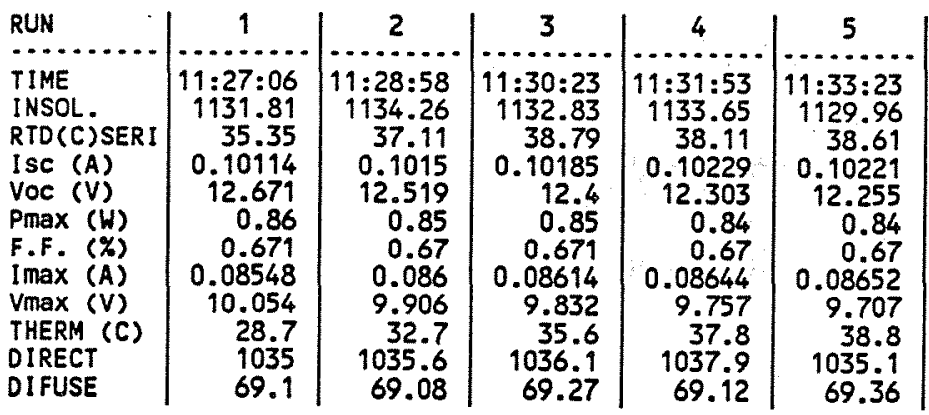

OUTDOOR DAY 3 (DEC. 3, 1988) PEP K\&Z PYRANOMETER

\begin{tabular}{l|r|r|r|r|r|} 
RUN & \multicolumn{1}{|c|}{1} & \multicolumn{1}{|c|}{2} & \multicolumn{1}{|c|}{3} & \multicolumn{1}{|c|}{5} \\
\hline TIME & $11: 24: 20$ & $11: 25: 46$ & $11: 27: 16$ & $11: 28: 45$ & $11.30: 52$ \\
INSOL. & 1097.16 & 1101.26 & 1100.23 & 1101.06 & 1099.83 \\
RTD(C)SERI & 24.99 & 28.58 & 29.82 & 31.08 & 31.74 \\
ISC (A) & 0.09967 & 0.09992 & 0.10008 & 0.10035 & 0.10042 \\
VOC (V) & 12.904 & 12.762 & 12.67 & 12.593 & 12.541 \\
Pmax (W) & 0.86 & 0.86 & 0.85 & 0.85 & 0.84 \\
F.F. (\%) & 0.67 & 0.671 & 0.67 & 0.67 & 0.67 \\
Imax (A) & 0.08433 & 0.08458 & 0.0847 & 0.08504 & 0.0851 \\
Vmax (V) & 10.211 & 10.112 & 10.038 & 9.963 & 9.917 \\
THERM (C) & 22.8 & 26.5 & 28.6 & 30.6 & 31.8 \\
DIRECT & 998.4 & 998.5 & 997.8 & 997.3 & 995.8 \\
DIFUSE & 78.32 & 78.56 & 78.69 & 79.18 & 80.34
\end{tabular}

INSOL., DIRECT, \& DIFUSE, MEASUREMENTS ARE REPORTED IN WATTS PER METER SQ. 


\section{Table C-2. Global Fixed-Tilt and SPI-SUN 240 Data for Sample RM-02}

SERI PV MEASUREMENTS AND PERFORMANCE BRANCH TEST REPORT \# 8918

TEST ITEM RM-02 (a-Si)

SPIRE SIMULATOR

\begin{tabular}{|c|c|c|c|c|c|c|c|}
\hline & $\begin{array}{c}\text { \$19 } \\
\text { |BASELINE }\end{array}$ & $\begin{array}{c}\mathbf{S 1 0} \\
\text { |STANDARD }\end{array}$ & $\begin{array}{l}\text { PEP } \\
\text { RC }\end{array}$ & $\begin{array}{l}\text { PEP } \\
\text { RM }\end{array}$ & $\begin{array}{c}\text { S19 } \\
\text { |BASELINE }\end{array}$ & $\begin{array}{c}\$ 19 \\
\text { |BASELINE }\end{array}$ & $\begin{array}{l}\text { *OUTDOOR* } \\
\text { BASELINE } \\
\text { |PSP(SERI) }\end{array}$ \\
\hline $\begin{array}{l}\text { INSOL. } \\
\text { RTD (C)SERI } \\
\text { ISC (A) } \\
\text { VOC (V) } \\
\text { Pmax (U) } \\
\text { F.F. (\%) } \\
\text { Imax (A) } \\
\text { Vmax (V) } \\
\text { THERM (C) }\end{array}$ & $\begin{array}{r}1000 \\
25 \\
0.104 \\
12.594 \\
0.78 \\
0.6 \\
0.089 \\
8.79\end{array}$ & $\begin{array}{r}1000 \\
25 \\
0.105 \\
12.629 \\
0.79 \\
0.5995 \\
0.088 \\
9.03 \\
.25\end{array}$ & $\begin{array}{r}1000 \\
25 \\
0.1 \\
12.585 \\
0.75 \\
0.599 \\
0.083 \\
9.08 \\
.25\end{array}$ & $\begin{array}{r}1000 \\
25 \\
0.098 \\
12.549 \\
0.74 \\
0.5991 \\
0.079 \\
9.33 \\
9.25\end{array}$ & $\begin{array}{r}1000 \\
20 \\
0.103 \\
12.818 \\
0.78 \\
0.59 \\
0.087 \\
8.98\end{array}$ & $\begin{array}{r}1000 \\
30 \\
0.105 \\
12.301 \\
0.78 \\
0.6 \\
0.09 \\
8.64\end{array}$ & $\begin{array}{r}1065.7 \\
25.6 \\
0.10571 \\
12.951 \\
0.81 \\
0.593 \\
0.08864 \\
9.158\end{array}$ \\
\hline
\end{tabular}

OUTDOOR DAY 1 (DEC. 1, 1988) PEP K\&Z PYRANOMETER

\begin{tabular}{l|r|r|r|r|r|r|} 
RUN & \multicolumn{1}{|c|}{1} & \multicolumn{1}{|c|}{2} & \multicolumn{1}{|c|}{3} & \multicolumn{1}{|c|}{5} & \multicolumn{1}{|c|}{5} & \multicolumn{1}{|c|}{6} \\
TIME & $14: 08: 42$ & $14: 10.08$ & $14: 11.35$ & $14: 13: 12$ & $14: 16: 15$ & $14: 17.53$ \\
INSOL. & 823.08 & 820.21 & 813.24 & 809.34 & 795.81 & 788.84 \\
RTD(C)SERI & 33.57 & 30.84 & 35.6 & 52.67 & 29.79 & 31.69 \\
ISC (A) & 0.07819 & 0.07763 & 0.07721 & 0.07678 & 0.07516 & 0.07465 \\
VoC (V) & 12.681 & 12.598 & 12.521 & 12.437 & 12.405 & 12.345 \\
Pmax (W) & 0.6 & 0.6 & 0.59 & 0.59 & 0.57 & 0.57 \\
F.F. (Y) & 0.61 & 0.611 & 0.613 & 0.615 & 0.616 & 0.617 \\
Imax (A) & 0.06523 & 0.06504 & 0.06485 & 0.06464 & 0.0634 & 0.06306 \\
Vmax (V) & 9.267 & 9.192 & 9.142 & 9.093 & 9.065 & 9.016 \\
THERM (C) & 24.1 & 26.2 & 28 & 30.1 & 30.7 & 32.1 \\
DIRECT & 907.7 & 903.7 & 902 & 899.9 & 891.9 & 889.8 \\
DIFUSE & 62.47 & 62.54 & 61.83 & 60.55 & 60.79 & 58.65
\end{tabular}

OUTDOOR. DAY 2 (DEC。2, 1988) PEP K\&Z PYRANOMETER

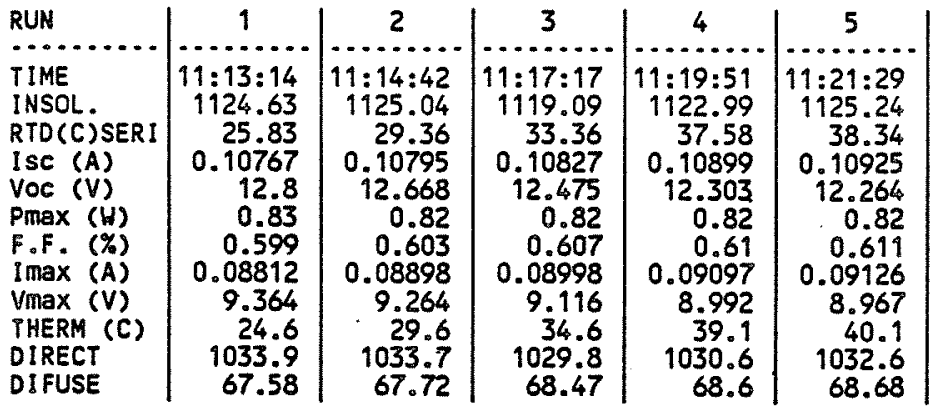

OUTDOOR DAY 3 (DEC. 3,1988 ) PEP K\&Z PYRANOMETER

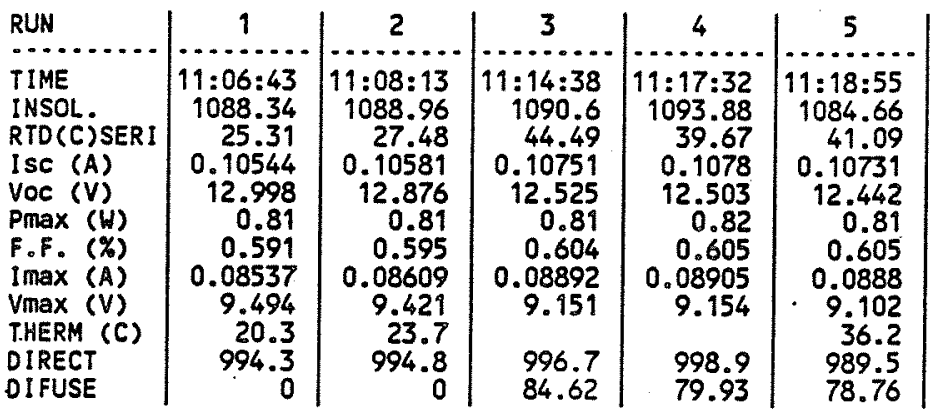

INSOL., DIRECT, \& DIFUSE, MEASUREMENTS ARE REPORTED IN WATTS PER METER SQ. 
Table C-3. Global Fixed-Tilt and SPI-SUN 240 Data for Sample RM-03 SERI PV MEASUREMENTS AND PERFORMANCE BRANCH TEST REPORT \# 8919

TEST ITEM RM-03 (CZ Si)

SPIRE SIMULATOR

\begin{tabular}{|c|c|c|c|c|c|c|c|c|c|c|}
\hline & & & & & & & & & & \\
\hline & & STANDARD & $\ldots$ & RM... & \begin{tabular}{|l} 
BASELINE \\
-..........
\end{tabular} & \begin{tabular}{|l} 
BASELINE \\
\hdashline...
\end{tabular} & $\mid$ PSPCS & \begin{tabular}{|l} 
BASELINE \\
......-
\end{tabular} & $\mid \begin{array}{l}\text { BASELINE } \\
. . . . . . .\end{array}$ & . \\
\hline $\begin{array}{l}\text { INSOL. } \\
\text { RTD (C)SERI } \\
\text { ISC (A) } \\
\text { VoC (V) } \\
\text { Pmax (W) } \\
\text { F.F. (\%) } \\
\text { Imax (A) } \\
\text { Vmax (V) } \\
\text { THERM (C) }\end{array}$ & $\begin{array}{r}1000 \\
25 \\
2.926 \\
0.5584 \\
1.17 \\
0.7169 \\
2.668 \\
0.44 \\
\text { OPEN }\end{array}$ & $\begin{array}{r}1000 \\
25 \\
2.953 \\
0.5612 \\
1.2 \\
0.7229 \\
2.754 \\
0.44 \\
\text { OPEN }\end{array}$ & $\begin{array}{r}1000 \\
25 \\
2.879 \\
0.5586 \\
1.16 \\
0.7227 \\
2.703 \\
0.43 \\
\text { OPEN }\end{array}$ & $\begin{array}{r}1000 \\
25 \\
2.832 \\
0.5572 \\
1.14 \\
0.7248 \\
2.605 \\
0.44 \\
\text { OPEN }\end{array}$ & $\begin{array}{r}1000 \\
19 \\
2.926 \\
0.5723 \\
1.24 \\
0.7382 \\
2.664 \\
0.46 \\
\text { OPEN }\end{array}$ & $\begin{array}{r}1000 \\
30 \\
2.934 \\
0.5432 \\
1.15 \\
0.7198 \\
2.637 \\
0.44 \\
\text { OPEN }\end{array}$ & $\begin{array}{r}1116.95 \\
19.61 \\
3.17204 \\
0.6 \\
1.38 \\
0.726 \\
2.89148 \\
0.478\end{array}$ & $\begin{array}{r}1000 \\
20 \\
2.902 \\
0.5717 \\
0.79 \\
0.48 \\
2.309 \\
0.34\end{array}$ & $\begin{array}{r}1000 \\
25 \\
2.99 \\
0.5586 \\
0.75 \\
0.46 \\
2.285 \\
0.33\end{array}$ & $\begin{array}{r}1000 \\
30 \\
2.918 \\
0.548 \\
0.73 \\
0.45 \\
2.289 \\
0.32\end{array}$ \\
\hline
\end{tabular}

OUTDOOR DAY 1 (DEC. 1,1988 ) PEP K\&Z PYRANOMETER

\begin{tabular}{|c|c|c|c|c|c|}
\hline UN & 1 & 2 & 3 & 4 & 5 \\
\hline $\begin{array}{l}\text { TIME } \\
\text { INSOL. } \\
\text { RTO(C) SERI } \\
\text { ISC (A) } \\
\text { VOC (V) } \\
\text { Pmax (W) } \\
\text { F.F. (X) } \\
\text { Imax (A) } \\
\text { Vmax (V) } \\
\text { THERM (C) } \\
\text { DIRECT } \\
\text { OIFUSE }\end{array}$ & $\begin{array}{r}12: 30: 30 \\
1091.01 \\
28.23 \\
3.12973 \\
0.591 \\
1.33 \\
0.72 \\
2.82557 \\
0.471 \\
\text { OPEN } \\
1018.6 \\
69.89\end{array}$ & $\begin{array}{r}12.33: 40 \\
1081.99 \\
35.42 \\
3.12928 \\
0.575 \\
1.28 \\
0.709 \\
2.79257 \\
0.457 \\
\text { OPEN } \\
1015.6 \\
69.3\end{array}$ & $\begin{array}{r}12: 35: 25 \\
1076.25 \\
38.04 \\
3.11128 \\
0.568 \\
1.25 \\
0.707 \\
2.79958 \\
0.446 \\
\text { OPEN } \\
1009.3 \\
69.79\end{array}$ & $\begin{array}{r}12.36: 58 \\
1071.33 \\
39.82 \\
3.10653 \\
0.564 \\
1.23 \\
0.703 \\
2.77021 \\
0.445 \\
\text { OPEN } \\
1007.4 \\
70.11\end{array}$ & $\begin{array}{r}12.38: 36 \\
1060.47 \\
40.68 \\
3.08257 \\
0.56 \\
1.21 \\
0.703 \\
2.75734 \\
0.441 \\
\text { OPEN } \\
1000 \\
69.93\end{array}$ \\
\hline
\end{tabular}

OUTDOOR DAY 2 (DEC. 2, 1988) PEP K\&Z PYRANOMETER

\begin{tabular}{|c|c|c|c|c|c|}
\hline UN & 1 & 2 & 3 & 4 & $5^{\circ}$ \\
\hline $\begin{array}{l}\text { TIME } \\
\text { INSOL. } \\
\text { RTD (C) SERI } \\
\text { I SC (A) } \\
\text { VOC (V) } \\
\text { Pmax (W) } \\
\text { F.F. (\%) } \\
\text { Imax (A) } \\
\text { Vmax (V) } \\
\text { THERM (C) } \\
\text { DIRECT } \\
\text { DIFUSE }\end{array}$ & $\begin{array}{r}10: 04: 24 \\
1031.77 \\
26.78 \\
2.8878 \\
0.592 \\
1.24 \\
0.728 \\
2.6262 \\
0.474 \\
\text { OPEN } \\
1005.9 \\
61.72\end{array}$ & $\begin{array}{r}10: 08: 48 \\
1035.45 \\
36.08 \\
2.93407 \\
0.571 \\
1.19 \\
0.713 \\
2.63485 \\
0.453 \\
\text { OPEN } \\
1009.9 \\
61.97\end{array}$ & $\begin{array}{r}10: 10: 34 \\
1036.48 \\
40.04 \\
2.95312 \\
0.566 \\
1.18 \\
0.708 \\
2.63696 \\
0.449 \\
\text { OPEN } \\
1012.4 \\
61.85\end{array}$ & $\begin{array}{r}10: 12: 41 \\
1034.43 \\
48.09 \\
2.93571 \\
0.561 \\
1.17 \\
0.71 \\
2.61892 \\
0.446 \\
\text { OPEN } \\
1005 \\
62.81\end{array}$ & $\begin{array}{r}10.14: 39 \\
1045.09 \\
56.62 \\
2.98874 \\
0.557 \\
1.17 \\
0.703 \\
2.65204 \\
0.441 \\
\text { OPEN } \\
1016.9 \\
62.88\end{array}$ \\
\hline
\end{tabular}

OUTDOOR DAY 3 (DEC. 3, 1988) PEP K\&Z PYRANOMETER

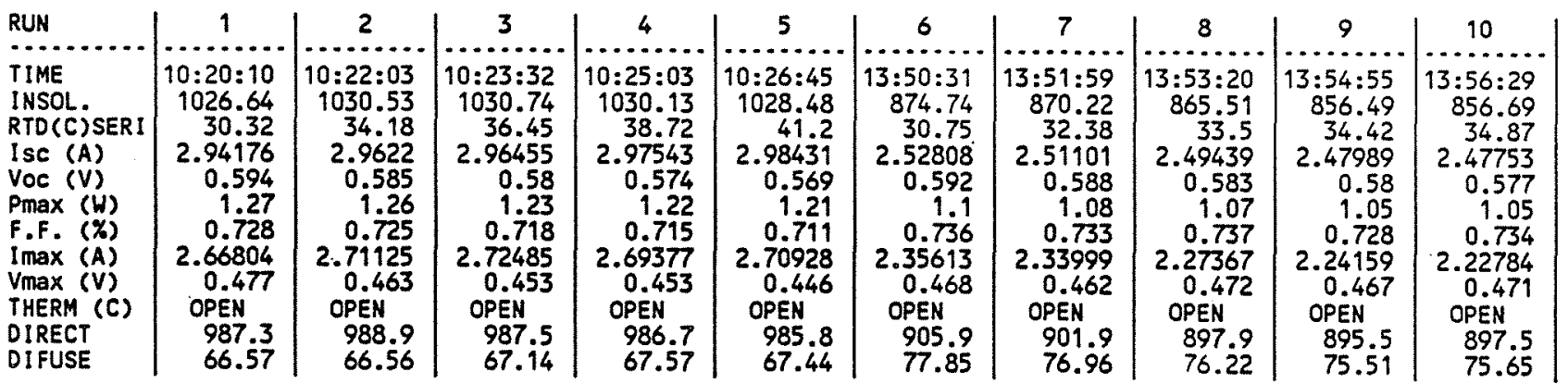

INSOL., DIRECT, \& DIFUSE, MEASUREMENTS ARE REPORTED IN WATTS PER METER SQ. 
Table C-4. Global Fixed-Tilt and SPI-SUN 240 Data for Sample RM-04

SERI PV MEASUREMENTS AND PERFORMANCE BRANCH TEST REPORT \# 8920

TEST ITEM RM-04 (C2 Si)

SPIRE SIMULATOR

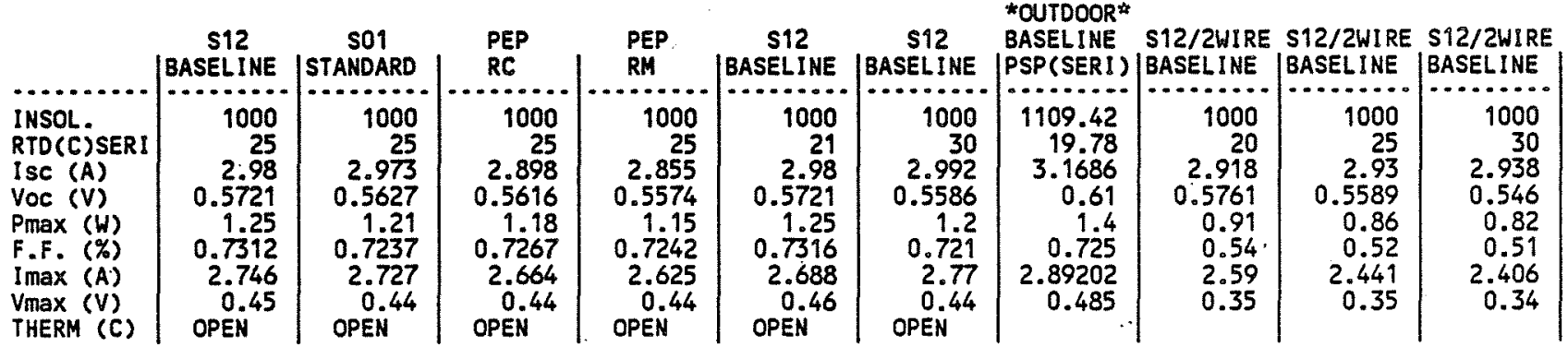

OUTDOOR DAY 1 (DEC. 1, 1988) PEP K\&Z PYRANOMETER

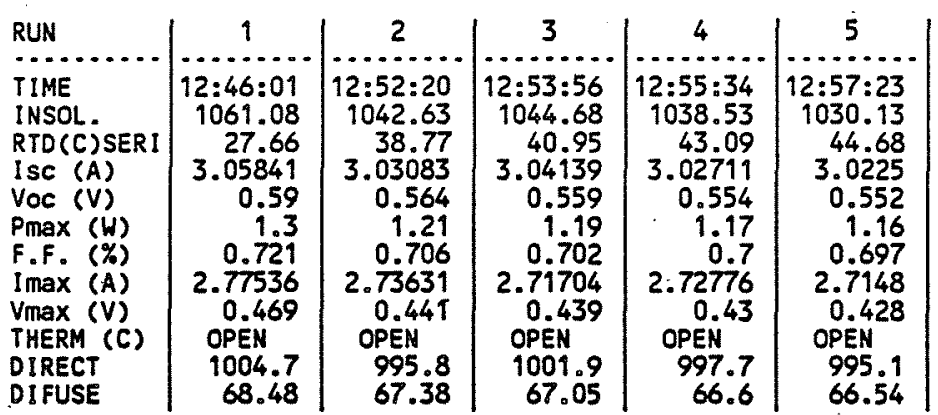

OUTDOOR DAY 2 (DEC. 2, 1988) PEP K\&Z PYRANOMETER

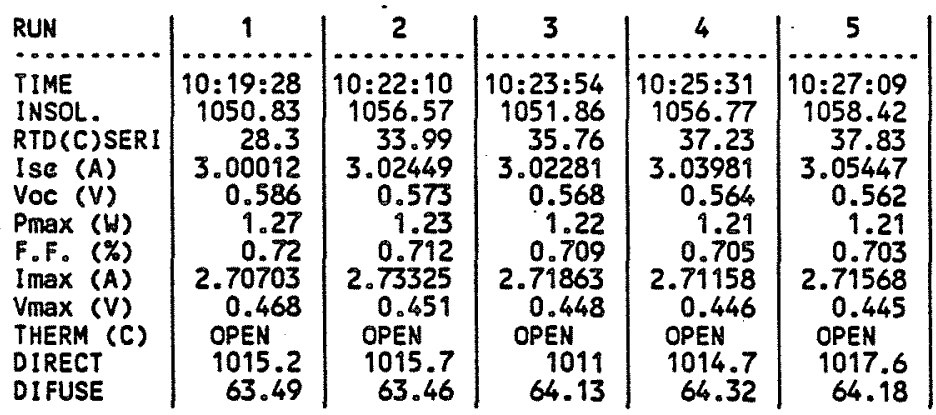

OUTDOOR DAY 3 (DEC. 3, 1988) PEP K\&Z PYRANOMETER

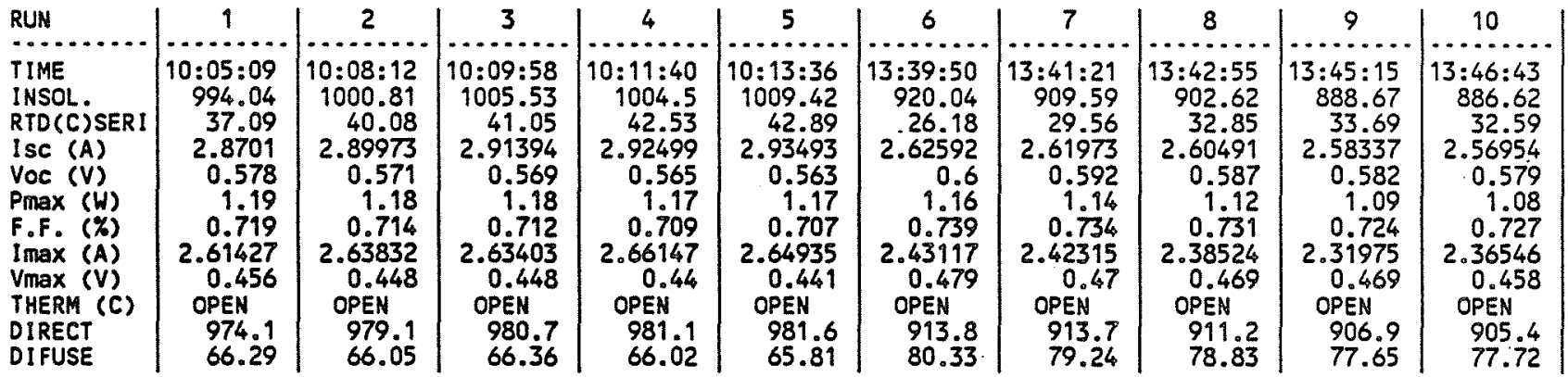

INSOL., DIRECT, \& DIFUSE, MEÁSUREMENTS ARE REPORTED IN WATTS PER METER SQ. 
Table C-5. Global Fixed-Tilt and SPI-SUN 240 Data for Sample RM-05 SERI PV MEASUREMENTS AND PERFORMANCE BRANCH TEST REPORT \# 8921 TEST ITEM RM-05 (me Si)

SPIRE SIMULATOR

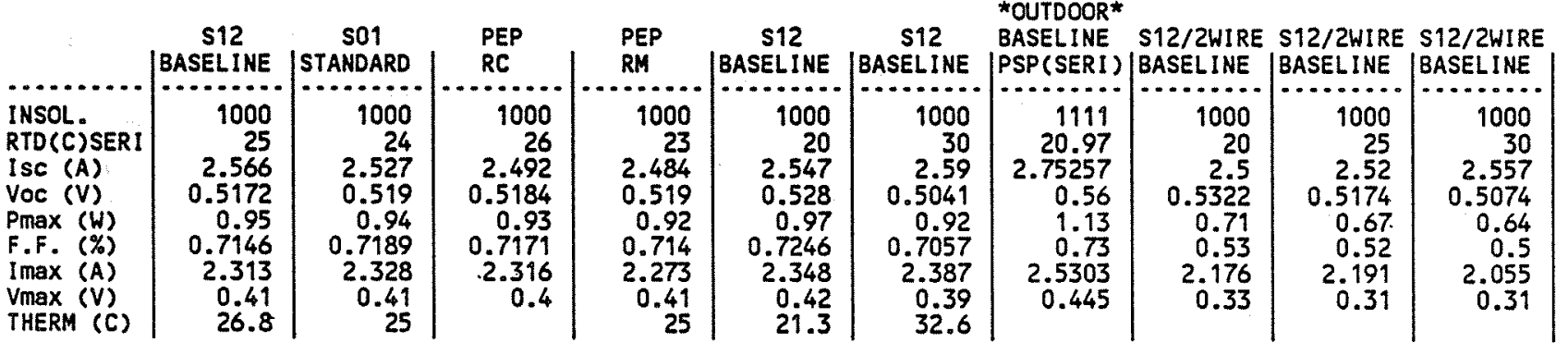

OUTDOOR DAY 1 (DEC. 1, 1988) PEP K\&Z PYRANOMETER

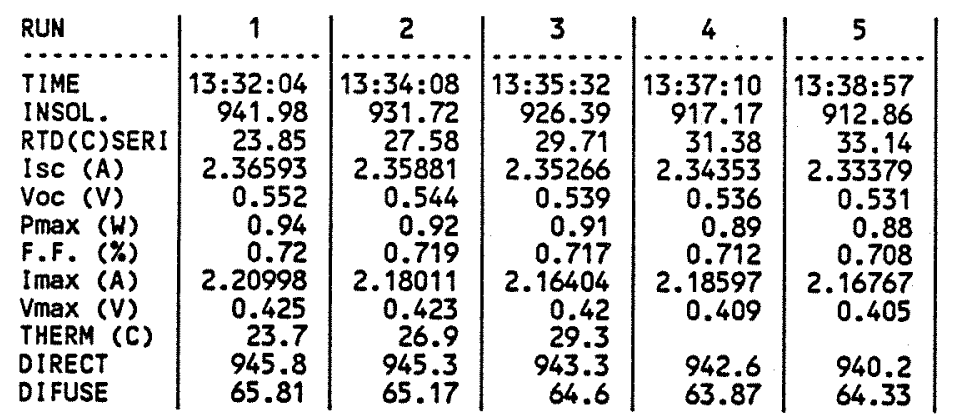

OUTDOOR DAY 2 (DEC. 2, 1988) PEP K\&Z PYRANOMETER

\begin{tabular}{|c|c|c|c|c|c|}
\hline RUN & 1 & 2 & 3 & 4 & 5 \\
\hline $\begin{array}{l}\text { TIME } \\
\text { INSOL. } \\
\text { RTD(C)SERI } \\
\text { ISC (A) } \\
\text { VOC (V) } \\
\text { Pmax (W) } \\
\text { F.F. (\%) } \\
\text { I max (A) } \\
\text { Vmax (V) } \\
\text { THERM (C) } \\
\text { DIRECT } \\
\text { DIFUSE }\end{array}$ & $\begin{array}{r}10: 33: 54 \\
1078.92 \\
22.86 \\
2.674 \\
0.558 \\
1.08 \\
0.722 \\
2.4449 \\
0.441 \\
22.9 \\
1027 \\
64.53\end{array}$ & $\begin{array}{r}10: 35: 28 \\
1082.81 \\
26.93 \\
2.69243 \\
0.548 \\
1.05 \\
0.715 \\
2.44305 \\
0.432 \\
27.4 \\
1025.4 \\
64.6\end{array}$ & $\begin{array}{r}10.36 .59 \\
1083.42 \\
30.24 \\
2.70838 \\
0.541 \\
1.04 \\
0.711 \\
2.44383 \\
0.426 \\
30.6 \\
1029.1 \\
64.56\end{array}$ & $\begin{array}{r}10: 38: 31 \\
1085.89 \\
31.48 \\
2.7222 \\
0.537 \\
1.03 \\
0.707 \\
2.43165 \\
0.425 \\
32.4 \\
1030.6 \\
64.52\end{array}$ & $\begin{array}{r}10: 40: 21 \\
1084.04 \\
33.44 \\
2.72644 \\
0.532 \\
1.02 \\
0.705 \\
2.44501 \\
0.418 \\
34.6 \\
1027.5 \\
64.84\end{array}$ \\
\hline
\end{tabular}

OUTDOOR DAY 3 (DEC. 3, 1988) PEP K\&Z PYRANOMETER

\begin{tabular}{|c|c|c|c|c|c|c|c|c|c|c|}
\hline RUN & 1 & 2 & 3 & 4 & 5 & 6 & 7 & 8 & 9 & 10 \\
\hline $\begin{array}{l}\text { TIME } \\
\text { INSOL. } \\
\text { RTD(C)SERI } \\
\text { ISC (A) } \\
\text { VOC (V) } \\
\text { Pmax (W) } \\
\text { F.F. (Y) } \\
\text { Imax (A) } \\
\text { Vmax (V) } \\
\text { THERM (C) } \\
\text { DIRECT } \\
\text { DIFUSE }\end{array}$ & $\begin{array}{r}13: 16: 56 \\
975.6 \\
38.34 \\
2.45385 \\
0.554 \\
0.98 \\
0.723 \\
2.27098 \\
0.433 \\
22.9 \\
934.7 \\
89.31\end{array}$ & $\begin{array}{r}13: 18: 22 \\
972.31 \\
37.14 \\
2.44714 \\
0.549 \\
0.97 \\
0.726 \\
2.24853 \\
0.433 \\
25.2 \\
931.1 \\
90.81\end{array}$ & $\begin{array}{r}13: 19: 47 \\
966.98 \\
40.96 \\
2.44124 \\
0.545 \\
0.96 \\
0.719 \\
2.22101 \\
0.431 \\
26.6 \\
928.5 \\
91.64\end{array}$ & $\begin{array}{r}13: 21: 15 \\
966.98 \\
39.94 \\
2.44016 \\
0.543 \\
0.95 \\
0.718 \\
2.24493 \\
0.424 \\
27.7 \\
928.4 \\
92.63\end{array}$ & $\begin{array}{r}13: 22: 48 \\
962.07 \\
46.35 \\
2.4323 \\
0.541 \\
0.94 \\
0.718 \\
2.1869 \\
0.432 \\
28.7 \\
925 \\
92.5\end{array}$ & $\begin{array}{r}14: 13.29 \\
792.12 \\
22.41 \\
2.00489 \\
0.549 \\
0.8 \\
0.726 \\
1.76663 \\
0.453 \\
22.5 \\
868.1 \\
77.89\end{array}$ & $\begin{array}{r}14: 16: 04 \\
788.63 \\
25.71 \\
1.99343 \\
0.542 \\
0.78 \\
0.722 \\
1.87548 \\
0.416 \\
25.8 \\
869 \\
76.97\end{array}$ & $\begin{array}{r}14: 17.26 \\
786.79 \\
26.68 \\
1.98759 \\
0.54 \\
0.78 \\
0.723 \\
1.84545 \\
0.421 \\
26.7 \\
867.6 \\
77.08\end{array}$ & $\begin{array}{r}14: 18: 51 \\
774.49 \\
27.44 \\
1.96721 \\
0.538 \\
0.76 \\
0.722 \\
1.71592 \\
0.445 \\
27.6 \\
861.4 \\
77.52\end{array}$ & $\begin{array}{r}14: 20: 18 \\
766.29 \\
27.38 \\
1.94897 \\
0.538 \\
0.76 \\
0.724 \\
1.73573 \\
0.437 \\
27.6 \\
855.8 \\
76.23\end{array}$ \\
\hline
\end{tabular}

INSOL., OIRECT, \& DIFUSE, MEASUREMENTS ARE REPORTED IN WATTS PER METER SQ. 
Table C-6. Global Fixed-Tilt and SPI-SUN 240 Data for Sample RM-06

SERI PV MEASUREMENTS AND PERFORMANCE BRANCH TEST REPORT \# 8922

TEST ITEM RM-06 (mC Si)

SPIRE SIMULATOR

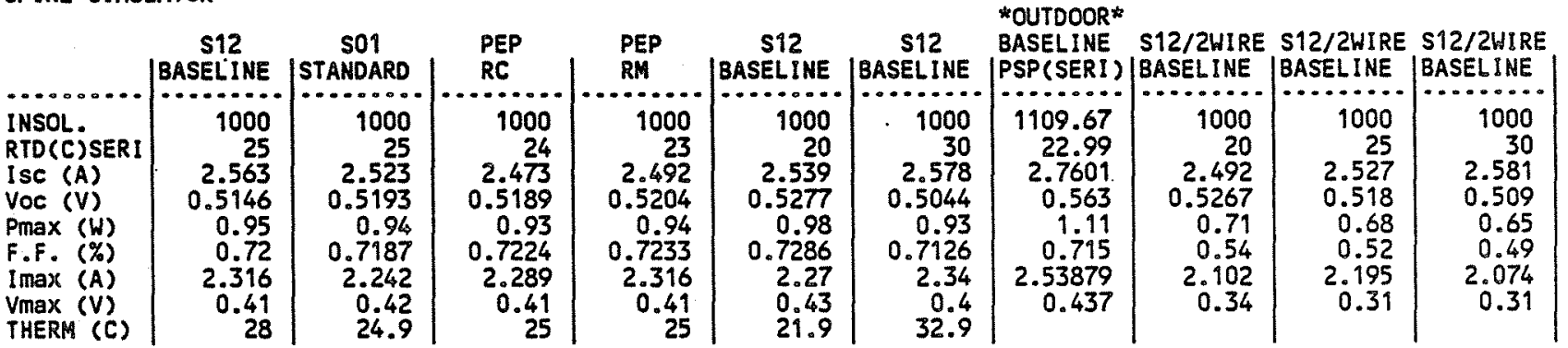

OUTDOOR DAY 1 (DEC. 1,1988 ) PEP K\&Z PYRANOMETER

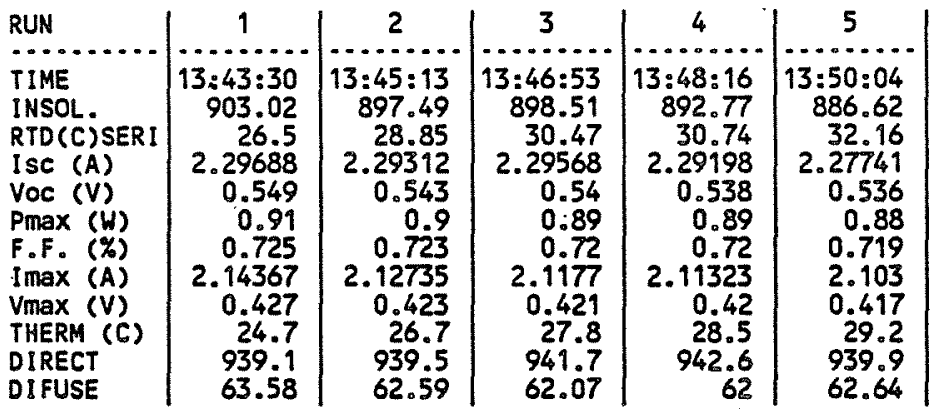

OUTDOOR DAY 2 (DEC. 2, 1988) PEP K\&Z PYRANOMETER

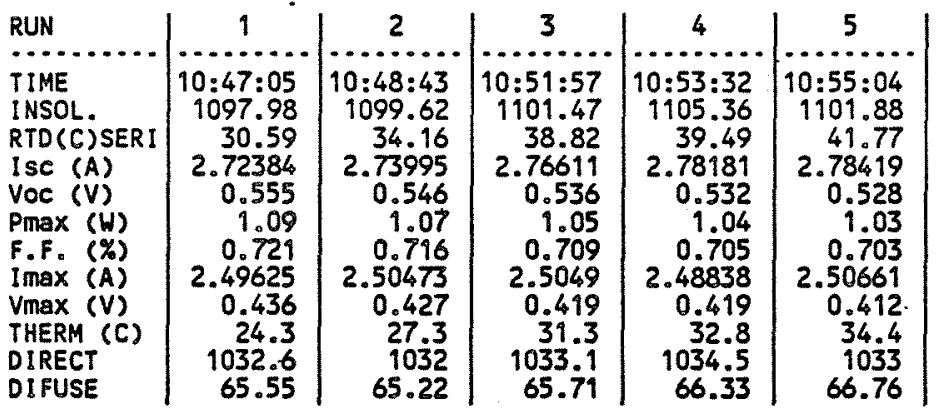

OUTDOOR DAY 3 (DEC. 3, 1988) PEP K\&Z PYRANOMETER

\begin{tabular}{|c|c|c|c|c|c|c|c|c|c|c|}
\hline RUN & 1 & 2 & 3 & 4 & 5 & 6 & 7 & 8 & 9 & . 10 \\
\hline $\begin{array}{l}\text { TIME } \\
\text { INSOL. } \\
\text { RTD (C)SERI } \\
\text { ISC (A) } \\
\text { VOC (V) } \\
\text { Pmax (W) } \\
\text { F.F. (X) } \\
\text { Imax (A) } \\
\text { Vmax (V) } \\
\text { THERM (C) } \\
\text { DIRECT } \\
\text { DIFUSE }\end{array}$ & $\begin{array}{r}13: 06: 18 \\
990.35 \\
32.57 \\
2.49548 \\
0.549 \\
0.99 \\
0.722 \\
2.30678 \\
0.429 \\
25.6 \\
945.3 \\
78.56\end{array}$ & $\begin{array}{r}13: 07: 46 \\
986.87 \\
34.5 \\
2.49652 \\
0.545 \\
0.98 \\
0.72 \\
2.28562 \\
0.429 \\
27.2 \\
944.4 \\
79.73\end{array}$ & $\begin{array}{r}13: 09: 14 \\
985.85 \\
36.37 \\
2.50352 \\
0.541 \\
0.97 \\
0.717 \\
2.28435 \\
0.425 \\
29.2 \\
945 \\
80.65\end{array}$ & $\begin{array}{r}13: 10: 41 \\
985.43 \\
37.38 \\
2.50054 \\
0.539 \\
0.96 \\
0.716 \\
2.28436 \\
0.422 \\
30.4 \\
943.6 \\
81.99\end{array}$ & $\begin{array}{r}13: 12: 15 \\
977.44 \\
37.56 \\
2.49031 \\
0.538 \\
0.96 \\
0.717 \\
2.27071 \\
0.423 \\
30.8 \\
940 \\
83.53\end{array}$ & $\begin{array}{r}14: 03: 44 \\
830.66 \\
28.43 \\
2.09095 \\
0.554 \\
0.84 \\
0.728 \\
1.82736 \\
0.462 \\
21.6 \\
883.1 \\
75.47\end{array}$ & $\begin{array}{r}14: 05: 16 \\
824.3 \\
29.28 \\
2.08248 \\
0.551 \\
0.84 \\
0.731 \\
1.93951 \\
0.432 \\
22.8 \\
881.1 \\
75.46\end{array}$ & $\begin{array}{r}14: 06: 47 \\
821.23 \\
30.07 \\
2.08046 \\
0.549 \\
0.84 \\
0.732 \\
1.93078 \\
0.433 \\
23.6 \\
883 \\
75.87\end{array}$ & $\begin{array}{r}14: 08.16 \\
813.03 \\
31.49 \\
2.06521 \\
0.545 \\
0.82 \\
0.729 \\
1.91641 \\
0.428 \\
25.2 \\
878.4 \\
76.84\end{array}$ & $\begin{array}{r}14: 09.38 \\
807.5 \\
32.28 \\
2.05057 \\
0.543 \\
0.81 \\
0.728 \\
1.89579 \\
0.428 \\
26 \\
873.3 \\
76.81\end{array}$ \\
\hline
\end{tabular}

INSOL., DIRECT, \& DIFUSE, MEASUREMENTS ARE REPORTED IN WATTS PER METER SQ. 
Table C-7. Global Fixed-Tilt and SPI-SUN 240 Data for Sample SM-01 SERI PV MEASUREMENTS AND PERFORMANCE BRANCH TEST REPORT \# 8923 TEST ITEM SM-01 (a-Si) SPIRE SIMULATOR

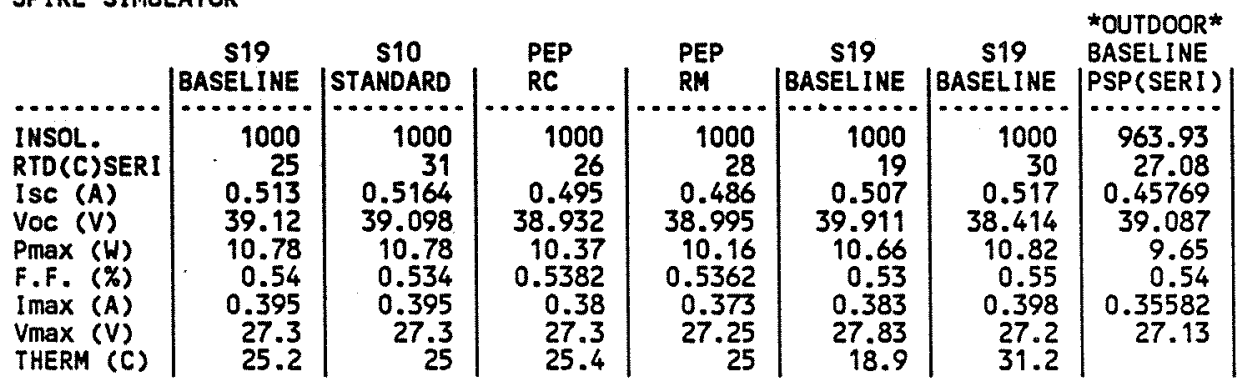

OUTDOOR DAY 1 (DEC. 1, 1988) PEP K\&Z PYRANOMETER

\begin{tabular}{|c|c|c|c|c|c|}
\hline RUN & 1 & $2^{\circ}$ & 3 & 4 & 5 \\
\hline $\begin{array}{l}\text { TIME } \\
\text { INSOL. } \\
\text { RTD(C) SERI } \\
\text { ISC (A) } \\
\text { VOC (V) } \\
\text { Pmax (W) } \\
\text { F.F. (\%) } \\
\text { Imax (A) } \\
\text { Vmax (V) } \\
\text { THERM (C) } \\
\text { DIRECT } \\
\text { OIFUSE }\end{array}$ & $\begin{array}{r}10: 19: 49 \\
1022.74 \\
32.68 \\
0.48445 \\
38.67 \\
10.18 \\
0.543 \\
0.37749 \\
26.964 \\
27.9 \\
988.4 \\
64.19\end{array}$ & $\begin{array}{r}10: 23: 42 \\
1001.42 \\
34.24 \\
0.476 \\
38.288 \\
9.95 \\
0.546 \\
0.37288 \\
26.681 \\
30.3 \\
957.9 \\
68.26\end{array}$ & $\begin{array}{r}10: 27: 10 \\
1006.35 \\
33.32 \\
0.47608 \\
38.274 \\
9.97 \\
0.547 \\
0.3739 \\
26.657 \\
31.7 \\
957 \\
68.64\end{array}$ & $\begin{array}{r}10: 28: 36 \\
1021.72 \\
35.46 \\
0.48777 \\
38.005 \\
10.16 \\
0.548 \\
0.38399 \\
26.466 \\
35.7 \\
974.5 \\
68.17\end{array}$ & $\begin{array}{r}10: 30: 13 \\
1023.77 \\
37.47 \\
0.48917 \\
37.734 \\
10.17 \\
0.551 \\
0.38699 \\
26.293 \\
36.8 \\
973.7 \\
69.09\end{array}$ \\
\hline
\end{tabular}

QUTDOOR DAY 2 (DEC. 2, 1988) PEP K\&Z PYRANOMETER

\begin{tabular}{|c|c|c|c|c|c|}
\hline RUN & 1 & 2 & 3 & 4 & 5 \\
\hline $\begin{array}{l}\text { TIME } \\
\text { INSOL. } \\
\text { RTD (C)SERI I ISC (A) } \\
\text { ISC (V) } \\
\text { VOC (V) } \\
\text { Pmax (W) } \\
\text { F.F. (\%) } \\
\text { Imax (A) } \\
\text { Vmax (V) } \\
\text { THERM (C) } \\
\text { DIRECT } \\
\text { DIFUSE }\end{array}$ & $\begin{array}{r}12: 01: 29 \\
1129.55 \\
33.2 \\
0.5194 \\
39.113 \\
10.91 \\
0.537 \\
0.40015 \\
27.267 \\
25.1 \\
1041.6 \\
68.86\end{array}$ & $\begin{array}{r}12: 03: 13 \\
1125.65 \\
38.37 \\
0.52233 \\
38.476 \\
10.92 \\
0.543 \\
0.40695 \\
26.824 \\
30.5 \\
1040.5 \\
68.54\end{array}$ & $\begin{array}{r}12: 07: 42 \\
1119.92 \\
41.76 \\
0.52012 \\
38.212 \\
10.83 \\
0.545 \\
0.40629 \\
26.648 \\
32.8 \\
1034.3 \\
69.09\end{array}$ & $\begin{array}{r}12: 09: 26 \\
1122.38 \\
45.15 \\
0.52332 \\
37.729 \\
10.84 \\
0.549 \\
0.4122 \\
26.303 \\
37.6 \\
1036.5 \\
68.81\end{array}$ & $\begin{array}{r}12: 12: 00 \\
1117.66 \\
46.81 \\
0.52322 \\
37.413 \\
10.79 \\
0.551 \\
0.41383 \\
26.08 \\
40.1 \\
1035.5 \\
68.66\end{array}$ \\
\hline
\end{tabular}

OUTDOOR DAY 3 (DEC. 3, 1988) PEP K\&Z PYRANOMETER

\begin{tabular}{|c|c|c|c|c|c|}
\hline RUN & 1 & 2 & 3 & 4 & 5 \\
\hline $\begin{array}{l}\text { TIME } \\
\text { INSOL. } \\
\text { RTD (C) SERI } \\
\text { ISC (A) } \\
\text { VOC (V) } \\
\text { Pmax (W) } \\
\text { F.F. (X) } \\
\text { Imax (A) } \\
\text { Vmax (V) } \\
\text { THERM (C) } \\
\text { DIRECT } \\
\text { DI FUSE }\end{array}$ & $\begin{array}{r}11: 43: 25 \\
1096.75 \\
40.92 \\
0.50652 \\
39.691 \\
10.6 \\
0.527 \\
0.38305 \\
27.678 \\
21.2 \\
988.5 \\
81.68\end{array}$ & $\begin{array}{r}11: 45: 29 \\
1097.16 \\
28.41 \\
0.51125 \\
38.991 \\
10.69 \\
0.536 \\
0.39312 \\
27.185 \\
27.1 \\
990.9 \\
82.22\end{array}$ & $\begin{array}{r}11: 46: 57 \\
1096.75 \\
30.52 \\
0.51328 \\
38.638 \\
10.7 \\
0.539 \\
0.39705 \\
26.939 \\
30.3 \\
991.9 \\
82.34\end{array}$ & $\begin{array}{r}11: 48: 31 \\
1093.68 \\
32.46 \\
0.51234 \\
38.341 \\
10.65 \\
0.542 \\
0.39855 \\
26.734 \\
32.6 \\
987.8 \\
82.84\end{array}$ & $\begin{array}{r}11: 50: 03 \\
1085.47 \\
35.16 \\
0.50986 \\
38.001 \\
10.57 \\
0.546 \\
0.39904 \\
26.487 \\
35.2 \\
982 \\
83.04\end{array}$ \\
\hline
\end{tabular}

INSOL., DIRECT, \& DIFUSE, MEASUREMENTS ARE REPORTED IN WATTS PER METER SQ. 
Table C-8. Global Fixed-Tilt and SPI-SUN 240 Data for Sample SM-02 SERI PV MEASUREMENTS ANO PERFORMANCE BRANCH TEST REPORT \# 8924 TEST ITEM SM-02 (a-Si) SPIRE SIMULATOR

\begin{tabular}{|c|c|c|c|c|c|c|c|}
\hline & $\begin{array}{c}519 \\
\text { |BASELINE }\end{array}$ & $\begin{array}{c}\text { S10 } \\
\text { |STAMDARD }\end{array}$ & $\begin{array}{l}\text { PEP } \\
\text { RC }\end{array}$ & $\begin{array}{l}\text { PEP } \\
\text { RM }\end{array}$ & $\begin{array}{c}\text { \$19 } \\
\text { |BASELINE }\end{array}$ & $\begin{array}{c}\text { S19 } \\
\text { |BASELINE }\end{array}$ & $\begin{array}{l}\text { *OUTDOOR* } \\
\text { BASELINE } \\
\text { |PSP(SERI) }\end{array}$ \\
\hline $\begin{array}{l}\text { INSOL. } \\
\text { RTO(C)SERI } \\
\text { ISC (A) } \\
\text { VOC (V) } \\
P \max (W) \\
\text { F.F. (\%) } \\
I \text { max (A) } \\
V \max (V)\end{array}$ & $\begin{array}{r}1000 \\
25 \\
0.52 \\
39.203 \\
10.66 \\
0.52 \\
0.385 \\
27.69 \\
\text { OPEN }\end{array}$ & $\begin{array}{r}1000 \\
29 \\
0.5248 \\
39.158 \\
10.75 \\
0.5231 \\
0.389 \\
27.64\end{array}$ & $\begin{array}{r}1000 \\
28 \\
0.4988 \\
39.108 \\
10.24 \\
0.5251 \\
0.376 \\
27.25\end{array}$ & $\begin{array}{r}1000 \\
27 \\
0.4922 \\
39.036 \\
10.06 \\
0.5238 \\
0.372\end{array}$ & $\begin{array}{r}1000 \\
21 \\
0.517 \\
39.86 \\
10.53 \\
0.51 \\
0.381 \\
27.64\end{array}$ & $\begin{array}{r}1000 \\
30 \\
0.526 \\
38.403 \\
10.76 \\
0.53 \\
0.4 \\
26.9\end{array}$ & $\begin{array}{r}974.86 \\
22.91 \\
0.47048 \\
39.41 \\
9.69 \\
0.523 \\
0.35361 \\
27.397\end{array}$ \\
\hline
\end{tabular}

OUTDOOR DAY 1 (DEC. 1,1988$)$ PEP K\&Z PYRANOMETER

\begin{tabular}{|c|c|c|c|c|c|}
\hline RUN & 1 & 2 & 3 & 4 & 5 \\
\hline $\begin{array}{l}\text { TIME } \\
\text { INSOL. } \\
\text { RTD(C)SERI } \\
\text { ISC (A) } \\
\text { VOC (V) } \\
\text { Pmax (W) } \\
\text { F.F. (X) } \\
\text { Imax (A) } \\
\text { Vmax (V) } \\
\text { THERM (C) } \\
\text { DIRECT } \\
\text { DIFUSE }\end{array}$ & $\begin{array}{r}10: 37: 26 \\
1035.25 \\
24.75 \\
0.50049 \\
39.01 \\
10.25 \\
0.525 \\
0.37742 \\
27.162 \\
26.3 \\
978 \\
69.6\end{array}$ & $\begin{array}{r}10: 39: 33 \\
1037.5 \\
28.85 \\
0.50376 \\
38.528 \\
10.29 \\
0.53 \\
0.38353 \\
26.843 \\
30.4 \\
976.2 \\
69.89\end{array}$ & $\begin{array}{r}10: 49: 13 \\
1040.99 \\
30.94 \\
0.50614 \\
38.245 \\
10.32 \\
0.533 \\
0.38747 \\
26.643 \\
32.8 \\
976.9 \\
70.49\end{array}$ & $\begin{array}{r}10: 43: 03 \\
1045.5 \\
33.69 \\
0.50952 \\
37.944 \\
10.38 \\
0.537 \\
0.39292 \\
26.424 \\
35.5 \\
979.8 \\
70.11\end{array}$ & $\begin{array}{r}10: 44: 35 \\
1047.55 \\
35.59 \\
0.51257 \\
37.711 \\
10.42 \\
0.539 \\
0.39647 \\
26.277 \\
37.6 \\
982.1 \\
69.94\end{array}$ \\
\hline
\end{tabular}

OUTDOOR DAY 2 (DEC. 2, 1988) PEP K\&Z PYRANOMETER

\begin{tabular}{|c|c|c|c|c|c|}
\hline RUN & 1 & 2 & 3 & 4 & 5 \\
\hline $\begin{array}{l}\text { TIME } \\
\text { INSOL. } \\
\text { RTD(C) SERI } \\
\text { ISC (A) } \\
\text { Voc (V) } \\
\text { Pmax (W) } \\
\text { F.F. (\%) } \\
\text { Imax (A) } \\
\text { Vmax (V) } \\
\text { THERM (C) } \\
\text { OIRECT } \\
\text { DIFUSE }\end{array}$ & $\begin{array}{r}11: 49: 11 \\
1126.47 \\
33.57 \\
0.53126 \\
38.921 \\
10.85 \\
0.525 \\
0.39981 \\
27.945 \\
26.9 \\
1038.9 \\
69.44\end{array}$ & $\begin{array}{r}11.50: 41 \\
1132.01 \\
38.09 \\
0.53552 \\
38.412 \\
10.92 \\
0.531 \\
0.40797 \\
26.778 \\
31.4 \\
1043.9 \\
68.86\end{array}$ & $\begin{array}{r}11: 52: 34 \\
1125.04 \\
42.59 \\
0.53482 \\
37.992 \\
10.9 \\
0.536 \\
0.41148 \\
26.483 \\
34.7 \\
1038.5 \\
68.91\end{array}$ & $\begin{array}{r}11: 54: 09 \\
1125.86 \\
47.61 \\
0.53713 \\
37.687 \\
10.9 \\
0.539 \\
0.41479 \\
26.286 \\
37.7 \\
1039.7 \\
68.94\end{array}$ & $\begin{array}{r}0.539 \\
37.43 \\
10.5 \\
0.5 \\
0.418 \\
26.1 \\
40 \\
1042 \\
69.3\end{array}$ \\
\hline
\end{tabular}

OUTDOOR DAY 3 (DEC. 3, 1988) PEP K\&Z PYRANOMETER

\begin{tabular}{|c|c|c|c|c|c|}
\hline RUN & 1 & 2 & 3 & 4 & 5 \\
\hline $\begin{array}{l}\text { TIME } \\
\text { INSOL. } \\
\text { RTD(C)SERI } \\
\text { I SC (A) } \\
\text { VoC (V) } \\
\text { Pmax (W) } \\
\text { F.F. ( ( ) } \\
\text { Imax (A) } \\
\text { Vmax (V) } \\
\text { THERM (C) } \\
\text { DIRECT } \\
\text { DIFUSE }\end{array}$ & $\begin{array}{r}11: 53.56 \\
1087.73 \\
22.53 \\
0.51471 \\
39.231 \\
10.5 \\
0.52 \\
0.38401 \\
27.34 \\
23.4 \\
983.6 \\
82.56\end{array}$ & $\begin{array}{r}11: 55: 29 \\
1091.42 \\
25.56 \\
0.51873 \\
38.83 \\
10.56 \\
0.524 \\
0.39017 \\
27.072 \\
27.3 \\
986.4 \\
82.27\end{array}$ & $\begin{array}{r}11: 56: 58 \\
1090.19 \\
28.14 \\
0.5208 \\
38.515 \\
10.61 \\
0.529 \\
0.39515 \\
26.85 \\
30.3 \\
987.5 \\
82.02\end{array}$ & $\begin{array}{r}11: 58: 26 \\
1094.7 \\
30.18 \\
0.52245 \\
38.303 \\
10.63 \\
0.531 \\
0.39844 \\
26.674 \\
32.4 \\
989.6 \\
82.09\end{array}$ & $\begin{array}{r}11: 59.52 \\
1092.24 \\
31.78 \\
0.52408 \\
38.119 \\
10.64 \\
0.533 \\
0.4004 \\
26.576 \\
34.3 \\
990.1 \\
82.05\end{array}$ \\
\hline
\end{tabular}

INSOL., DIRECT, \& DIFUSE, MEASUREMENTS ARE REPORTED IN WATTS PER METER SQ. 
Table C-9. Global Fixed-Tilt and SPI-SUN 240 Data for Sample SM-03 SERI PV MEASUREMENTS AND PERFORMANCE BRANCH TEST REPORT \# 8925 TEST ITEM SM-03 (CZ Si) SPIRE SIMULATOR

\begin{tabular}{|c|c|c|c|c|c|c|c|}
\hline & $\begin{array}{c}\text { S12 } \\
\text { |BASELINE }\end{array}$ & $\begin{array}{c}\text { S01 } \\
\text { |STANDARD }\end{array}$ & $\begin{array}{l}\text { PEP } \\
\text { RC }\end{array}$ & $\begin{array}{l}\text { PEP } \\
\text { RM }\end{array}$ & $\begin{array}{c}\$ 12 \\
\text { |BASELINE }\end{array}$ & $\begin{array}{c}\$ 12 \\
\text { |BASELINE }\end{array}$ & $\begin{array}{l}\text { *OUTDOOR* } \\
\text { BASELINE } \\
\text { PSP (SERI) }\end{array}$ \\
\hline $\begin{array}{l}\text { INSOL } \\
\text { RTD (C) SERI } \\
\text { ISC (A) } \\
\text { VOC (V) } \\
\text { Pmax (W) } \\
\text { F.F. (\%) } \\
\text { Imax (A) } \\
\text { Vmax (V) } \\
\text { THERM (C) }\end{array}$ & $\begin{array}{r}1000 \\
25 \\
2.902 \\
21.278 \\
47.6 \\
0.77 \\
2.723 \\
17.48 \\
\text { NO } \mathrm{iC}\end{array}$ & $\begin{array}{r}1000 \\
25 \\
2.891 \\
21.359 \\
47.86 \\
0.7752 \\
2.723 \\
17.58 \\
\text { No iC }\end{array}$ & $\begin{array}{r}1000 \\
25 \\
2.836 \\
21.05 \\
46.07 \\
0.7718 \\
2.621 \\
17.58 \\
\text { NO TC }\end{array}$ & $\begin{array}{r}1000 \\
25 \\
2.781 \\
21.138 \\
45.51 \\
0.7742 \\
2.633 \\
17.29 \\
\text { NO TC }\end{array}$ & $\begin{array}{r}1000 \\
19 \\
2.895 \\
21.75 \\
48.8 \\
0.78 \\
2.746 \\
17.77 \\
\text { NO TC }\end{array}$ & $\begin{array}{r}1000 \\
30 \\
2.914 \\
20.809 \\
46.27 \\
0.76 \\
2.715 \\
17.04 \\
\text { NO } \mathrm{TC}\end{array}$ & $\begin{array}{r}929.8 \\
33.27 \\
2.63743 \\
21.229 \\
42.72 \\
0.763 \\
2.47061 \\
17.29\end{array}$ \\
\hline
\end{tabular}

OUTDOOR DAY 1 (DEC. 1, 1988) PEP K\&Z PYRANOMETER

\begin{tabular}{l|r|r|r|r|r|} 
RUN & 1 & \multicolumn{1}{|c|}{2} & 3 & 4 & \multicolumn{1}{|c|}{5} \\
TIME & $11: 52: 19$ & $11: 54: 03$ & $11: 56: 18$ & $11: 58: 40$ & $12: 00: 11$ \\
INSOL. & 1102.28 & 1109.05 & 1094.29 & 1103.51 & 1107.41 \\
RTD(C)SERI & 36.92 & 36.72 & 48.78 & 69.1 & 50.64 \\
ISC (A) & 3.16091 & 3.17547 & 3.16134 & 3.1854 & 3.19095 \\
VOC (V) & 21.239 & 20.872 & 20.427 & 20.153 & 20.063 \\
Pmax (W) & 50.64 & 49.73 & 47.98 & 47.47 & 47.21 \\
F.F. (\%) & 0.754 & 0.75 & 0.743 & 0.739 & 0.737 \\
ImaX (A) & 2.9617 & 2.95733 & 2.91797 & 2.92356 & 2.91873 \\
Vmax (V) & 17.097 & 16.817 & 16.442 & 16.237 & 16.176 \\
THERM (C) & NO TC & NO TC & NO TC & NO TC & NO TC \\
DIRECT & 1010.2 & 1012.6 & 1003.3 & 1013.1 & 1014.6 \\
DIFUSE & 73.16 & 73.91 & 73.35 & 72.84 & 72.7
\end{tabular}

OUTDOOR DAY 2 (DEC. 2, 1988) PEP K\&Z PYRANOMETER

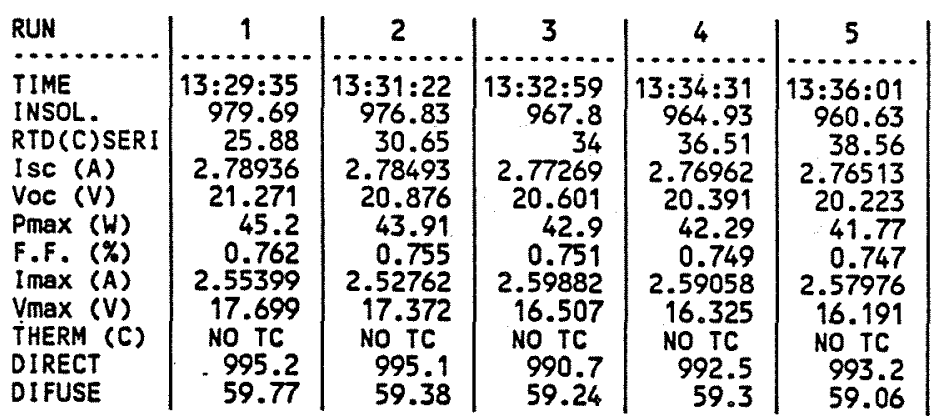

OUTDOOR DAY 3 (DEC. 3,1988 ) PEP K\&Z PYRANOMETER

\begin{tabular}{l|r|r|r|r|r|} 
RUN & 1 & 2 & 3 & 4 & 5 \\
\hline TIME & $10.35: . . .22$ & $10: 36: 33$ & $10.38: 02$ & $10: 39: 45$ & $10: 41: 15$ \\
INSOL. & 1044.47 & 1049.8 & 1049.19 & 1046.12 & 1049.19 \\
RTD (C)SERI & 24.26 & 28.46 & 31.61 & 34.3 & 36.78 \\
ISC (A) & 2.98053 & 2.99082 & 2.99739 & 3.0039 & 3.01194 \\
VOC (V) & 21.386 & 21.078 & 20.841 & 20.617 & 20.487 \\
Pmax (W) & 48.5 & 47.65 & 47.05 & 46.44 & 46.17 \\
F.F. (\%) & 0.761 & 0.756 & 0.753 & 0.75 & 0.748 \\
Imax (A) & 2.72149 & 2.71427 & 2.81122 & 2.80173 & 2.80488 \\
Vmax (V) & 17.822 & 17.554 & 16.736 & 16.577 & 16.459 \\
THERM (C) & NO TC & NO TC & NO TC & NO TC & NO TC \\
DIRECT & 987.7 & 988.2 & 987 & 984.2 & 985 \\
DIFUSE & 69.55 & 69.77 & 70.1 & 70.74 & 71.66
\end{tabular}

INSOL., DIRECT, \& DIFUSE, MEASUREMENTS ARE REPORTED IN WATTS PER METER SQ. 
Table C-10. Global Fixed-Tilt and SPI-SUN 240 Data for Sample SM-04

SERI PV MEASUREMENTS AND PERFORMANCE BRANCH TEST REPORT \# 8926

TEST ITEM SM=04 (CZ Si)

SPIRE SIMULATOR

\begin{tabular}{|c|c|c|c|c|c|c|c|}
\hline & $\begin{array}{c}\text { S12 } \\
\text { |BASELIHE }\end{array}$ & $\begin{array}{c}\text { SO1 } \\
\text { STANDARD }\end{array}$ & $\begin{array}{l}\text { PEP } \\
\text { RC }\end{array}$ & $\begin{array}{l}\text { PEP } \\
\text { RM }\end{array}$ & $\begin{array}{c}\$ 12 \\
\text { |BASELINE }\end{array}$ & $\begin{array}{c}\$ 12 \\
\text { BBASELINE }\end{array}$ & $\begin{array}{l}\text { NOUTDOOR* } \\
\text { BASELINE } \\
\text { (PSP (SERI) }\end{array}$ \\
\hline $\begin{array}{l}\text { INSOL. } \\
\text { RTD(C)SERI } \\
\text { IsC (A) } \\
\text { Voc (V) } \\
\text { Pmax (W) } \\
\text { F.F. (\%) } \\
\text { Imax (A) } \\
\text { Vmax (V) }\end{array}$ & $\begin{array}{r}1000 \\
25 \\
2.934 \\
21.22 \\
47.27 \\
0.76 \\
2.727 \\
17.33\end{array}$ & $\begin{array}{r}1000 \\
25 \\
2.938 \\
21.282 \\
47.6 \\
0.7612 \\
2.723 \\
17.48\end{array}$ & $\begin{array}{r}1000 \\
25 \\
2.855 \\
21.149 \\
46.29 \\
0.7666 \\
2.648 \\
17.48\end{array}$ & $\begin{array}{r}1000 \\
24 \\
2.805 \\
21.205 \\
45.74 \\
0.769 \\
2.602 \\
17.58\end{array}$ & $\begin{array}{r}1000 \\
20 \\
2.93 \\
21.637 \\
48.52 \\
0.77 \\
2.73 \\
17.77\end{array}$ & $\begin{array}{r}1000 \\
30 \\
2.941 \\
20.82 \\
46.06 \\
0.75 \\
2.703 \\
17.04\end{array}$ & $\begin{array}{r}923.12 \\
43.76 \\
2.64087 \\
21.237 \\
42.26 \\
0.754 \\
2.34147 \\
18.05\end{array}$ \\
\hline
\end{tabular}

OUTDOOR DAY 1 (DEC. 1, 1988) PEP K\&Z PYRANOMETER

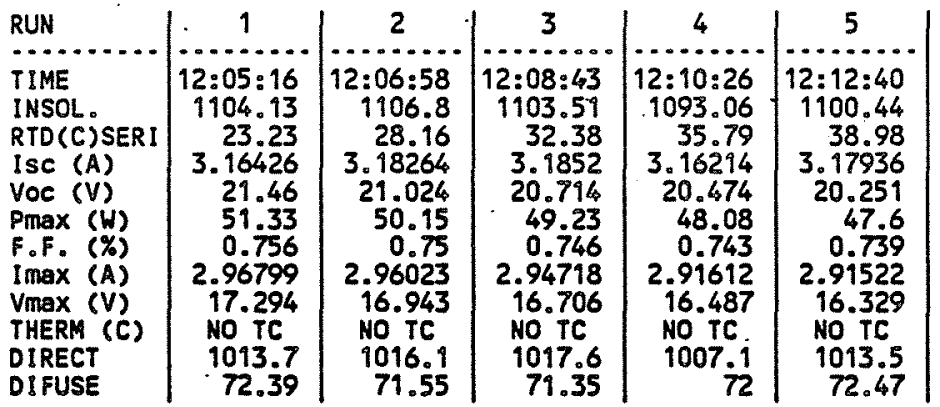

OUTDOOR DAY 2 (DEC. 2, 1988) PEP K\&Z PYRANOMETER

\begin{tabular}{|c|c|c|c|c|c|}
\hline \multicolumn{6}{|l|}{ RUN } \\
\hline \multicolumn{6}{|c|}{$\ldots \ldots$} \\
\hline INSOL. & 950.79 & 946.48 & 939.31 & 928.85 & 10.4 \\
\hline $\begin{array}{l}\text { RTD (C) SER I } \\
\text { ISC (A) }\end{array}$ & $\begin{array}{r}33.32 \\
2.72175\end{array}$ & $\begin{array}{r}36.55 \\
2.71383\end{array}$ & 279 & $\begin{array}{r}43.62 \\
260057\end{array}$ & 4 \\
\hline Voc $(V)$ & 21.128 & 20.835 & 20.596 & 20.232 & \\
\hline $\begin{array}{l}P \max (W) \\
F,(\%)\end{array}$ & 43.59 & 42.58 & 41.75 & 40.53 & \\
\hline$I \max (A)$ & 2.47 & 2.456 & 2.53 & 2.49 & 2.4 \\
\hline$V \max (V)$ & 17.587 & 17. & 16. & 16.231 & 16 \\
\hline THERM (C) & & No & & No & \\
\hline & & & & & \\
\hline
\end{tabular}

OUTDOOR DAY 3 (DEC. 3, 1988) PEP K\&Z PYRANOMETER

\begin{tabular}{|c|c|c|c|c|c|}
\hline \multicolumn{6}{|l|}{ RUN } \\
\hline TIME & \multicolumn{5}{|c|}{$\ldots \ldots$} \\
\hline INSOL. & 1066.62 & 1061.9 & 1059.44 & 1062.31 & \\
\hline $\begin{array}{l}\text { RTD (C)SER I } \\
\text { I SC (A) }\end{array}$ & $\begin{array}{r}42.43 \\
3.04756\end{array}$ & $\begin{array}{r}37.54 \\
3.05158\end{array}$ & $\begin{array}{r}39.98 \\
3.05591\end{array}$ & $\begin{array}{r}45.8 \\
3.05904\end{array}$ & 34 \\
\hline Voc (V) & 21.351 & 21.07 & 20.852 & 20.687 & 689 \\
\hline$P \max (W)$ & 49.16 & 48.39 & 47.74 & 47.36 & \\
\hline $1 \max (A)$ & 2. & 2.83399 & 2.83514 & 281827 & \\
\hline Vmax (V) & 17.2 & 17. & 16.837 & 16. & 805 \\
\hline THERM (C) & & & & & \\
\hline & & & & & 74.7 \\
\hline
\end{tabular}

INSOL., DIRECT, \& DIFUSE, MEASUREMENTS ARE REPORTED IN WATTS PER METER SQ. 
Table C-11. Global Fixed-Tilt and SPI-SUN 240 Data for Sample SM-05 SERI PV MEASUREMENTS AND PERFORMANCE BRANCH TEST REPORT \# 8927 TEST ITEM SM-05 (CZ Si) SPIRE SIMULATOR

\begin{tabular}{|c|c|c|c|c|c|c|c|}
\hline & $\begin{array}{c}\text { S12 } \\
\text { BASELINE }\end{array}$ & $\begin{array}{c}\text { S01 } \\
\text { STANDARD }\end{array}$ & $\begin{array}{l}\text { PEP } \\
\text { RC }\end{array}$ & $\begin{array}{l}\text { PEP } \\
\text { RM }\end{array}$ & $\begin{array}{c}\text { S12 } \\
\text { |BASELINE }\end{array}$ & $\begin{array}{c}512 \\
\text { |BASELINE }\end{array}$ & $\begin{array}{l}\text { *OUTDOOR* } \\
\text { BASELLINE } \\
\text { |PSP(SERI) }\end{array}$ \\
\hline $\begin{array}{l}\text { INSOL } \\
\text { RTD (C) } \\
\text { ISC (A) } \\
\text { VoC (V) } \\
\text { Pmax (W) } \\
\text { F.F. (\%) } \\
\text { Imax (A) } \\
\text { Vmax (V) } \\
\text { THERM (C) }\end{array}$ & $\begin{array}{r}1000 \\
25 \\
2.629 \\
10.864 \\
20.16 \\
0.71 \\
2.332 \\
8.64 \\
\text { NO TC }\end{array}$ & $\begin{array}{r}1000 \\
25 \\
2.586 \\
10.902 \\
20.34 \\
0.7214 \\
2.34 \\
8.69 \\
\text { NO TC }\end{array}$ & $\begin{array}{r}1000 \\
25 \\
2.543 \\
10.903 \\
20.07 \\
0.7238 \\
2.309 \\
8.69 \\
\text { NO TC }\end{array}$ & $\begin{array}{r}1000 \\
25 \\
2.559 \\
10.85 \\
19.96 \\
0.7189 \\
2.336 \\
8.55 \\
\text { NO TC }\end{array}$ & $\begin{array}{r}1000 \\
20 \\
2.602 \\
19.199 \\
20.87 \\
0.72 \\
2.348 \\
8.89 \\
\text { NO TC }\end{array}$ & $\begin{array}{r}1000 \\
30 \\
2.648 \\
10.626 \\
19.7 \\
0.7 \\
2.359 \\
8.35 \\
\text { NO TC }\end{array}$ & $\begin{array}{r}949.84 \\
34.97 \\
2.40332 \\
11.151 \\
19.46 \\
0.726 \\
2.18583 \\
8.902\end{array}$ \\
\hline
\end{tabular}

OUTDOOR DAY 1 (DEC. 1, 1988) PEP K\&Z PYRANOMETER

\begin{tabular}{l|r|r|r|r|r|} 
RUN & 1 & \multicolumn{1}{|c|}{2} & \multicolumn{1}{|c|}{3} & 4 & 5. \\
\hline TIME & $11: 38: 36$ & $11: 40: 30$ & $11: 42: 30$ & $11: 44: 10$ & $11: 45: 42$ \\
INSOL. & 1109.87 & 1108.43 & 1108.64 & 1107.62 & 1104.33 \\
RTD(C)SERI & 51.7 & 44.42 & 41.7 & 43.97 & 44.96 \\
ISC (A) & 2.8411 & 2.85001 & 2.85525 & 2.85516 & 2.85045 \\
VOC (V) & 10.839 & 10.673 & 10.599 & 10.526 & 10.489 \\
Pmax (W) & 21.72 & 21.26 & 21.07 & 20.87 & 20.72 \\
F.F. (X) & 0.705 & 0.699 & 0.696 & 0.695 & 0.693 \\
Imax (A) & 2.57425 & 2.55829 & 2.55537 & 2.5525 & 2.53698 \\
Vmax (V) & 8.438 & 8.31 & 8.247 & 8.178 & 8.168 \\
THERM (C) & NO TC & NO TC & NO TC & NO TC & NO TC \\
DIRECT & 1015.5 & 1013.5 & 1013.8 & 1012 & 1009.6 \\
DIFUSE & 73.5 & 73.26 & 73.23 & 72.75 & 72.97
\end{tabular}

OUTDOOR DAY 2 (DEC. 2, 1988)'PEP K\&Z PYRANOMETER

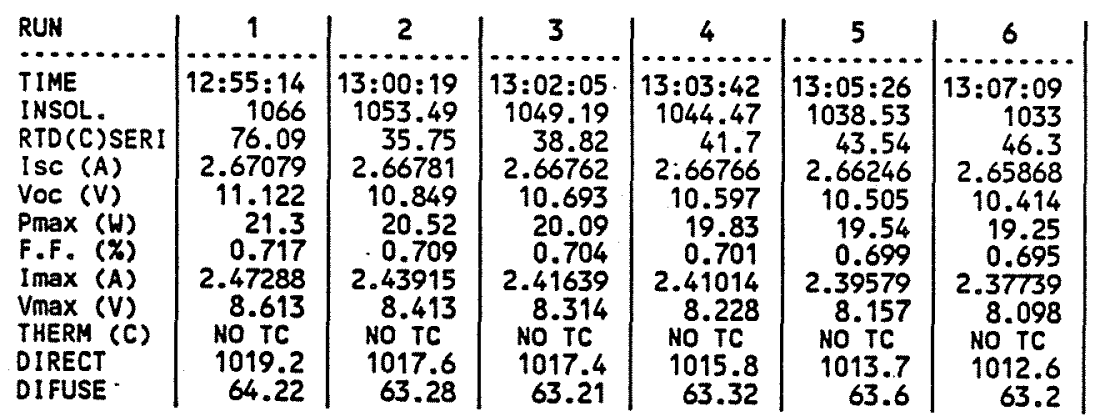

OUTDOOR DAY 3 (DEC. 3,1988 ) PEP K\&Z PYRANOMETER

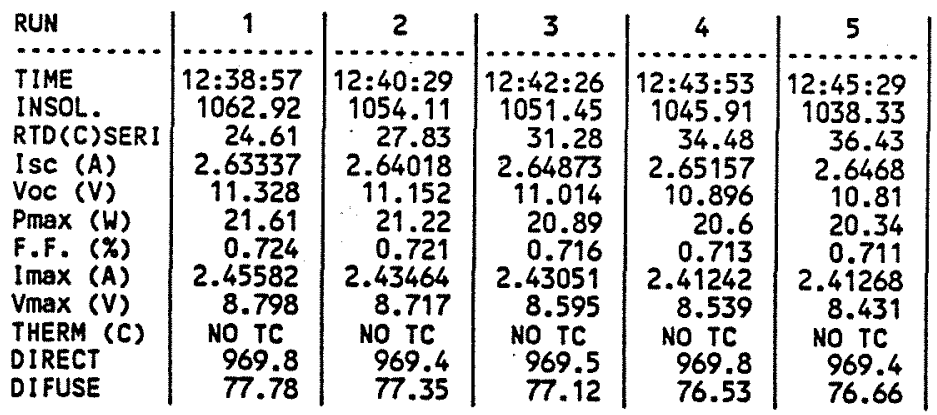

INSOL., DIRECT, \& DIFUSE, MEASUREMENTS ARE REPORTED IN WATTS PER METER SO. 
Table C-12. Global Fixed-Tilt and SPI-SUN 240 Data for Sample SM-06 SERI PV MEASUREMENTS AND PERFORMANCE BRANCH TEST REPORT \# 8928 TEST ITEM SM-06 (CZ Si) SPIRE SIMULATOR

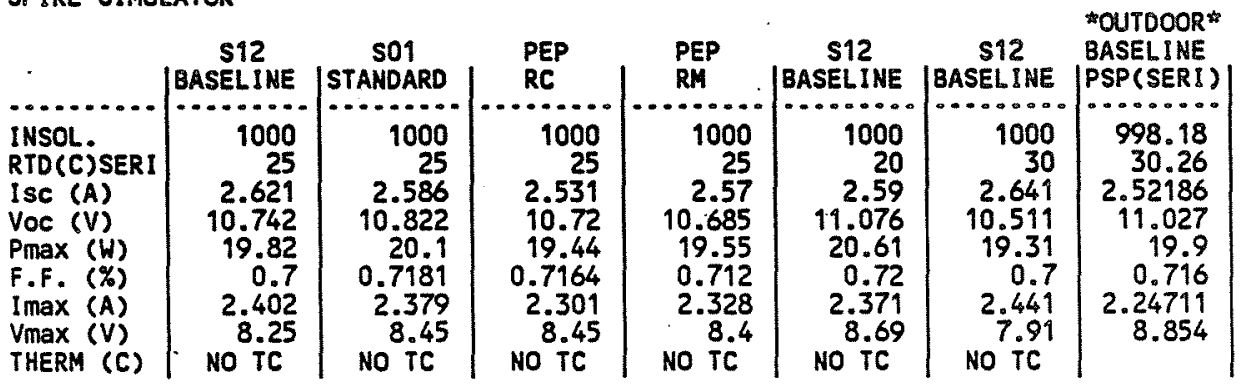

QUTDOOR DAY 1 (DEC. 1,1988 ) PEP K\&Z PYRANOMETER

\begin{tabular}{|c|c|c|c|c|c|}
\hline & 1 & 2 & 3 & 4 & 5 \\
\hline $\begin{array}{l}\text { TIME } \\
\text { INSOL. } \\
\text { RTD(C) SERI } \\
\text { ISC (A) } \\
\text { VOC (V) } \\
\text { Pmax (W) } \\
\text { F.F. (Y) } \\
\text { Imax (A) } \\
\text { Vmax (V) } \\
\text { THERM (C) } \\
\text { DIRECT } \\
\text { DIFUSE }\end{array}$ & $\begin{array}{r}11: 22: 04 \\
1101.88 \\
36.71 \\
2.78828 \\
11.123 \\
22.1 \\
0.713 \\
2.56579 \\
8.614 \\
\text { No TC } \\
1006.7 \\
73.51\end{array}$ & $\begin{array}{r}11: 23: 41 \\
1102.49 \\
36.15 \\
2.80544 \\
10.916 \\
21.64 \\
0.707 \\
2.5593 \\
8.456 \\
N 0 \mathrm{TC} \\
1007.1 \\
73.23\end{array}$ & $\begin{array}{r}11: 25: 16 \\
1102.69 \\
39.03 \\
2.82245 \\
10.789 \\
21.34 \\
0.701 \\
2.54784 \\
8.377 \\
\text { No TC } \\
1008.2 \\
73.31\end{array}$ & $\begin{array}{r}11: 32.55 \\
1107.41 \\
46.68 \\
2.86017 \\
10.491 \\
20.67 \\
0.689 \\
2.53979 \\
8.14 \\
\text { No TC } \\
1014.2 \\
72.49\end{array}$ & $\begin{array}{r}11: 29: 08 \\
1107.62 \\
43.91 \\
2.85404 \\
10.563 \\
20.86 \\
0.692 \\
2.54576 \\
8.193 \\
\text { No TC } \\
1014.2 \\
72.67\end{array}$ \\
\hline
\end{tabular}

OUTDOOR DAY 2 (DEC. 2, 1988) PEP K\&Z PYRANOMETER

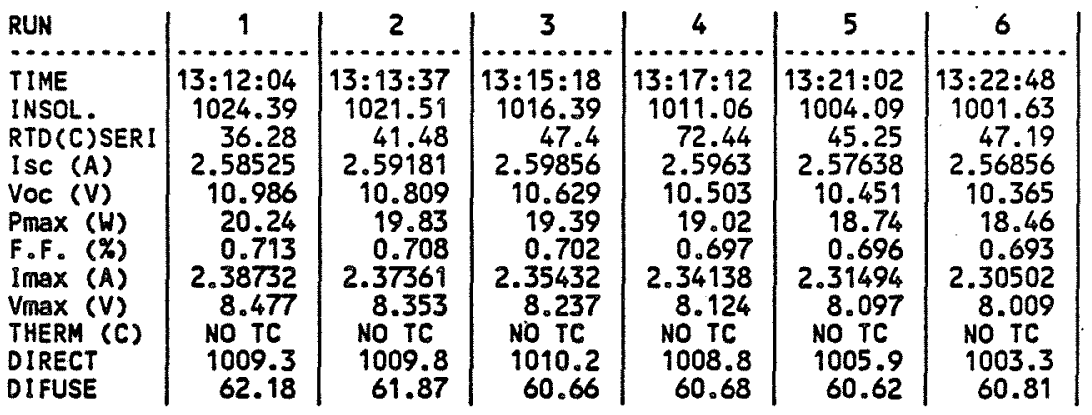

OUTDOOR DAY 3 (DEC. 3, 1988) PEP K\&Z PYRANOMETER

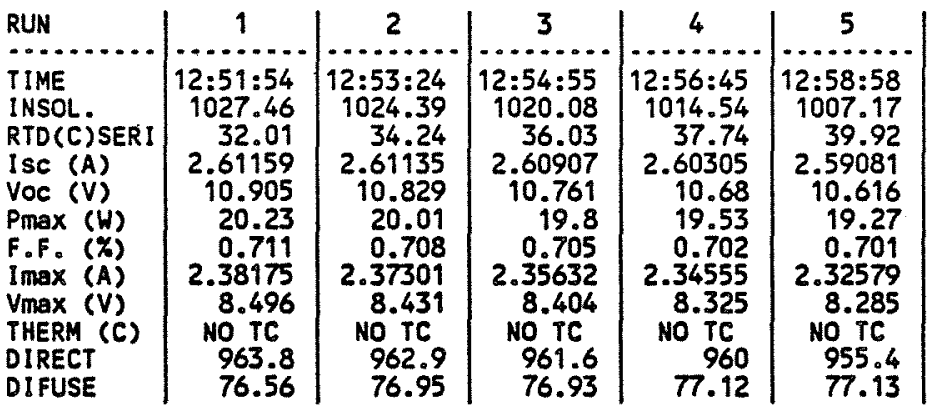

INSOL., DIRECT, \& DIFUSE, MEASUREMENTS ARE REPORTED IN WATTS PER METER SQ. 


\begin{tabular}{|c|c|}
\hline \begin{tabular}{c|c|c}
$\begin{array}{c}\text { Document Control } \\
\text { Page }\end{array}$ & $\begin{array}{c}\text { 1. SERI Report No. } \\
\text { SERI/STR-213-3472 Accession No. }\end{array}$ & DE89000896
\end{tabular} & 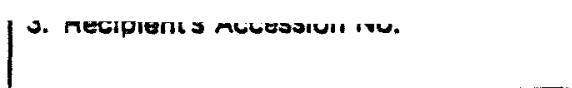 \\
\hline \multirow{2}{*}{$\begin{array}{l}\text { 4. Title and Subtitle } \\
\text { SERI Results from the PEP } 1987 \text { Summit Round Robin and } \\
\text { a Comparison of Photovoltaic Calibration Methods }\end{array}$} & $\begin{array}{l}\text { 5. Publication Date } \\
\text { March } 1989\end{array}$ \\
\hline & 6. \\
\hline $\begin{array}{l}\text { 7. Author(s) K.A. Emery, D. Waddington, S. Rummel, D.R. Myers } \\
\text { T.L. Stoffel, and C.R. Osterwald }\end{array}$ & 8. Pertorming Organization Rept. No. \\
\hline $\begin{array}{l}\text { 9. Performing Organization Name and Address } \\
\text { Solar Energy Research Institute } \\
1617 \text { Cole Boulevard } \\
\text { Golden, Colorado } 80401-3393\end{array}$ & $\begin{array}{l}\text { 10. Project/Task/Work Unit No. } \\
\text { PV920202, } 920601,810201 \\
\text { 11. Contract (C) or Grant (G) No. } \\
\text { (C) } \\
\text { (G) }\end{array}$ \\
\hline \multirow[t]{2}{*}{ 12. Sponsoring Organization Name and Address } & $\begin{array}{l}\text { 13. Type of Report \& Period Covered } \\
\text { Technical Report }\end{array}$ \\
\hline & 14. \\
\hline \multicolumn{2}{|l|}{ 15. Supplementary Notes } \\
\hline \multicolumn{2}{|c|}{ 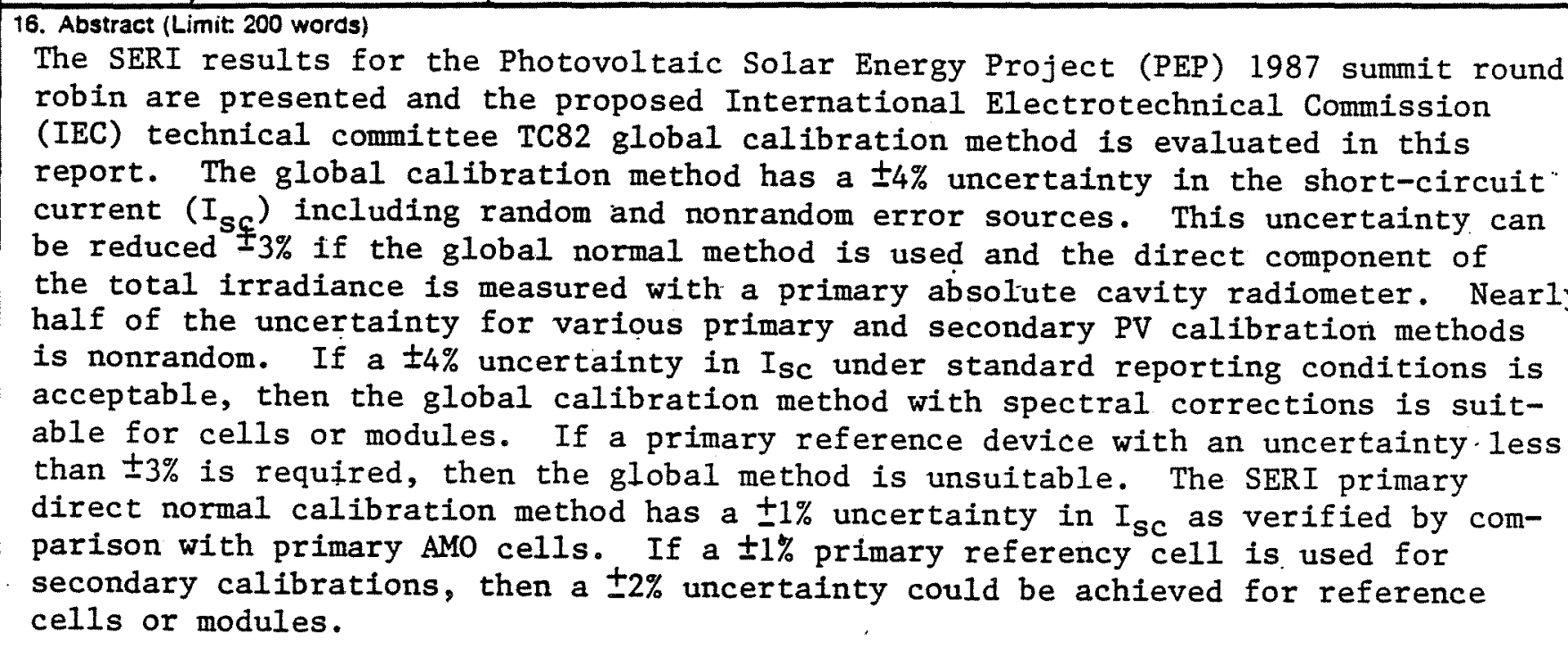 } \\
\hline \multirow{2}{*}{\multicolumn{2}{|c|}{$\begin{array}{l}\text { 17. Document Analysis } \\
\text { a. Descriptors Pho }\end{array}$}} \\
\hline & \\
\hline \multicolumn{2}{|l|}{ c. UC Categories 270} \\
\hline \multirow{4}{*}{$\begin{array}{l}\text { National Technical Information Service } \\
\text { U.S. Department of Commerce } \\
5285 \text { Port Royal Road }\end{array}$} & 19. No. of Pages \\
\hline & \\
\hline & 20. Price \\
\hline & A05 \\
\hline
\end{tabular}

